\author{
UNIVERSIDADE DE SÃO PAULO \\ FACULDADE DE FILOSOFIA, LETRAS E CIÊNCIAS HUMANAS \\ DEPARTAMENTO DE LETRAS CLÁSSICAS E VERNÁCULAS \\ PROGRAMA DE PÓS-GRADUAÇÃO EM ESTUDOS COMPARADOS \\ DE LITERATURAS DE LÍNGUA PORTUGUESA
}

ISABELA DA HORA TRINDADE

Páginas Íntimas - o Diário Extravagante de Lima Barreto (versão corrigida)

São Paulo 2012 


\author{
UNIVERSIDADE DE SÃO PAULO \\ FACULDADE DE FILOSOFIA, LETRAS E CIÊNCIAS HUMANAS \\ DEPARTAMENTO DE LETRAS CLÁSSICAS E VERNÁCULAS \\ PROGRAMA DE PÓS-GRADUAÇÃO EM ESTUDOS COMPARADOS \\ DE LITERATURAS DE LÍNGUA PORTUGUESA
}

\title{
Páginas Íntimas - o Diário Extravagante de Lima Barreto
}

(versão corrigida)

Isabela da Hora Trindade

\begin{abstract}
Dissertação apresentada ao Programa de Pós-Graduação em Estudos Comparados de Literaturas de Língua Portuguesa da Faculdade de Filosofia, Letras e Ciências Humanas da Universidade de São Paulo para a obtenção do título de Mestre em Letras.
\end{abstract}

Orientadora: Profa. Dra. Fabiana Buitor Carelli

São Paulo

2012 
FOLHA DE APROVAÇÃO

Isabela da Hora Trindade

Páginas Íntimas - o Diário Extravagante de Lima Barreto

Dissertação apresentada ao Programa de Pós-Graduação em Estudos Comparados de Literaturas de Língua Portuguesa da Faculdade de Filosofia, Letras e Ciências Humanas da Universidade de São Paulo para a obtenção do título de Mestre em Letras.

Aprovada em:

Orientadora:

Fabiana Buitor Carelli

Banca examinadora:

Helder Garmes

Ligia Fonseca Ferreira 
Aos meus,

Lucio e Dinélia, que me ensinaram

a voar fora da asa 


\section{Agradeço}

A Capes pela bolsa concedida, possibilitando que me dedicasse mais detidamente à pesquisa.

A professora Fabiana Buitor Carelli pela sábia orientação do trabalho e receptiva acolhida ainda no estágio de Iniciação Científica.

Ao professor Helder Garmes por compor a banca de qualificação e defesa, aconselhando-me precisamente, sobretudo, no que diz respeito à questão racial, objeto de análise nessa dissertação. Obrigada ainda pelo elucidativo encontro depois da disciplina de pós ministrada e pelas preciosas indicações bibliográficas via e-mail.

A professora Ligia Ferreira, primeira orientadora, a quem devo a brilhante indicação do Diário Íntimo de Lima Barreto para estudo. Pelo carinho, paciência, solicitude e por me ensinar as sendas da pesquisa acadêmica, agradeço. Obrigada também pelos conselhos valiosos não apenas na banca de qualificação e defesa, como em conversas trocadas informalmente, graças aos elos que nos unem - a paixão por Lima Barreto e pelo francês.

Sou grata ainda aos professores Vima Lia de Rossi Martin, Sara Albieri, Lilia Moritz Schwarcz e Kabengele Munanga com os quais muito aprendi ao cursar as disciplinas por eles ministradas.

As amigas queridas - Ligia Rivello, Zaine Câmara e Stella Pereira, companheiras da graduação, que viram nascer essa pesquisa e escutaram pacientemente minhas ideias. Exprimo aqui meu reconhecimento pelos ternos gestos, torcida sincera, leitura atenta. Sou grata ainda a Luana Tamano pela leitura cuidadosa do meu texto e pelas conversas calorosas sobre nossos 
temas de pesquisa. Aos amigos, de perto e de longe - Mariana Thomaz, Dieik Câmara, Paulo Vieira, Marcos Roberto do Nascimento, Gabriela Oliveira, Mariana Carvalho, Marciano Júnior, dentre tantos outros - meus sinceros agradecimentos pelo incentivo à realização desse projeto.

Aos meus pais pela compreensão e amor diários e, especialmente, por me oferecerem condições materiais para me dedicar ao que mais prezo - o estudo. Aos meus amados familiares (de São Paulo e da Bahia) muito obrigada pelo apoio e estímulo constantes, fundamental para que prosseguisse nessa empreitada. A minha família eternizo aqui minha gratidão.

A Deus pela inspiração, força e amor incondicional. 


\section{Resumo}

Esta dissertação propõe-se a analisar o Diário Íntimo do escritor carioca Lima Barreto (1881-1922) do ponto de vista formal do gênero diário. Assim procedendo, investigaremos de que modo se constituiu essa obra, com o intuito de levantar hipóteses interpretativas no que tange às motivações, necessidades e préstimos das páginas íntimas para esse autor mantido à margem do círculo intelectual canônico de seu tempo. Visamos a refletir, no plano literário, sobre o olhar de Lima voltado para os modelos estrangeiros, sobretudo para as referências francesas, largamente presentes em suas notas. Focalizaremos, no plano social, sua condição mestiça a partir dos relatos de situações cotidianas e comentários perspicazes, que demonstram a forma como a sociedade encarava aqueles marcados pela cor negra, da perspectiva limabarretiana. Nesse sentido, é nossa intenção avaliar a maneira como Lima Barreto apreendeu a sociedade brasileira de seu tempo no tocante à complexa e escorregadia questão racial, bem como observar os efeitos das teorias raciais importadas da Europa no âmago de sua trajetória enquanto negro escritor. Em suma, buscaremos compreender como os traços presentes no Diário revelam as referências e intencionalidades de Lima Barreto num contexto mais alargado, que se quer pessoal, racial, social e cultural de sua época.

Palavras-chave: Literatura Brasileira; Gênero Diário; Relações França-Brasil; Teorias Raciais; Lima Barreto. 


\begin{abstract}
This dissertation intends to analyze the Diário Íntimo (Intimate Diary) of the writer from Rio de Janeiro Lima Barreto (1881-1922) from the formal point of view of a diary genre. Thus, we are going to investigate the way this work is built, with the purpose of formulating interpretive hypothesis concerning the motivations, necessities and uses of the intimate pages for this author being kept far from the canonical circle of his time. We mean to reflect upon the literary aspect, about the view of Lima concentrated on the foreign models, above all the French references largely present on his notes. We are going to focus on the social aspect of his mestizo characteristic starting from the reports of daily situations and perspicacious comments, that demonstrate the way society faced those of black skin, within the Lima Barreto perspective. This way, it is our intention to analyze how Lima Barreto grasped the Brazilian society of his time in relation to the complex and slippery racial issue, as well as observe the effects of the racial theories imported from Europe at the core of his trajectory as a black writer. In short, we are going to search to understand how the features present in Diary reveal the references and intentions of Lima Barreto within an enlarged context of his time that is personal, racial, social and cultural.
\end{abstract}

Key words: Brazilian literature; Diary Genre; Brazil-France Relations;

Racial Theories; Lima Barreto. 


\section{Sumário}

Introdução

1. O Gênero Diário: a Sensação na Origem da Razão ............................. 25

1.1 O Universo Particular das Páginas Íntimas ....................................... 27

1.2 Traços Estéticos do Diário Íntimo .................................................... 40

1.3 Diário Íntimo e Autobiografia ........................................................... 50

1.40 Diário Íntimo por Francisco de Assis Barbosa ................................. 53

1.5De Extravagante a Íntimo: o Diário de Lima Barreto ............................. 55

2. O Rio de Janeiro no limiar do século XX - Lima Barreto em Cena ...... 82

2.1 As Leituras de Lima Barreto ....................................................... 92

2.2 Marcas Francesas no Diário Íntimo ………………....................... 96

2.3 Referências Literárias Francesas Comentadas no Diário Íntimo ......... 102

2.4 O Germinal Negro ........................................................................ 114

2.5 O Destino da Literatura para Lima Barreto ....................................... 126

3. Brasil: o Projeto de Nação para um Povo Mestiço .............................. 129

3.1 A Falsa Medida das Teorias Raciais no Brasil ................................. 138

3.2 O Aguilhoar das Teorias Raciais na Trajetória de Lima Barreto .......... 152

3.3 Lima Barreto na Confluência das Teorias Raciais .............................. 168

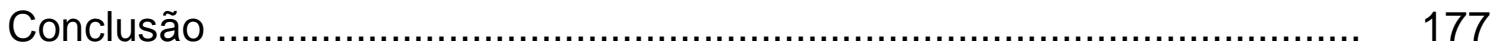

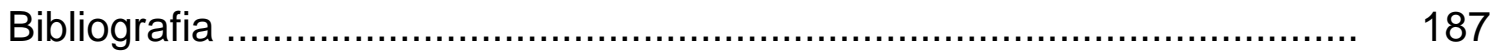

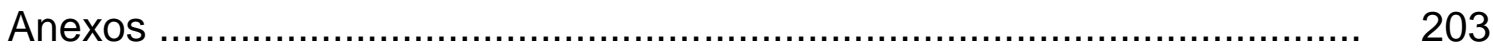

1. Cronologia de Lima Barreto ................................................... 204

2. Letra do samba enredo da Unidos da Tijuca em homenagem a Lima Barreto ....

3. Fotos busto de Lima Barreto .................................................... 213

4. Folheto ilustrativo da "Casa Lima Barreto" .................................... 215 


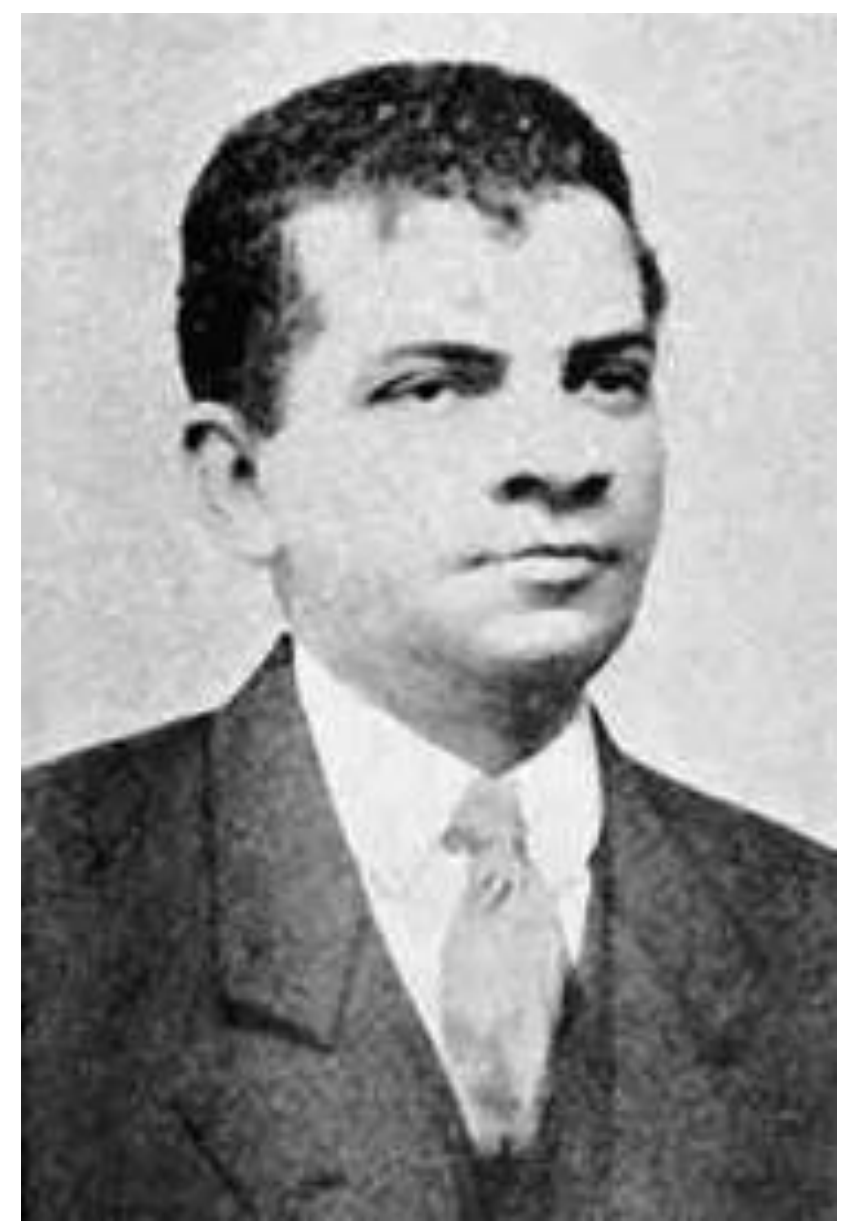

"Eu sou Afonso Henriques de Lima Barreto. Tenho vinte e dois anos. Sou filho legítimo de João Henriques de Lima Barreto. Fui aluno da Escola Politécnica. No futuro, escreverei a História da Escravidão Negra no Brasil e sua influência na nossa nacionalidade."

(Diário Íntimo) 


\section{Introdução}

Este projeto de pesquisa nasceu do contato com a Área de Estudos Comparados de Literaturas de Língua Portuguesa, quando ao cursarmos a disciplina "Introdução aos Estudos Comparados de Literaturas de Língua Portuguesa II", em 2005, passamos a nos interessar atentamente pela questão do negro no Brasil. A partir disso, começamos a pensar em pesquisar algum autor negro brasileiro que apresentasse relação com a França, uma vez que também nos interessamos pelas relações culturais França-Brasil.

Após efetuarmos algumas pesquisas na biblioteca central da Faculdade de Filosofia, Letras e Ciências Humanas (FFLCH) e no Instituto de Estudos Brasileiros (IEB), ambos da Universidade de São Paulo, travamos conhecimento com a obra do escritor carioca Lima Barreto (1881-1922). Inicialmente, aconselhamo-nos com a professora Ligia Ferreira que, naquele momento, compunha a área de língua e literatura francesa do curso de Letras da Universidade de São Paulo, cuja linha de pesquisa volta-se para aspectos interculturais França-Brasil, além de ter trabalhos sobre literatura e autores negros brasileiros. Ela sugeriu-nos, como pista provável para pesquisa, que associasse nossos dois campos de interesse, a leitura do Diário Íntimo, de Lima Barreto. Tal leitura foi reveladora, pois nos deparamos com número expressivo de referências a autores, obras e periódicos franceses, além de reflexões acerca da condição do negro/ mestiço na sociedade brasileira no limiar do século XX.

Tomando como ponto de partida as referências ao universo francês presentes no Diário Íntimo, realizamos um projeto de Iniciação Científica, 
oficialmente ao longo dos anos de 2007 e 2008, mas sob orientação da professora Fabiana Carelli da Área de Estudos Comparados de Literaturas de Língua Portuguesa, porque nos interessava estudar, no âmbito da literatura brasileira, os modelos que provavelmente influenciaram Lima Barreto, sem perder de vista as questões raciais implicadas no tratamento conferido a esse autor mantido à margem do campo literário de seu tempo.

O projeto de Iniciação Científica, cujo título foi - "As leituras francesas de Lima Barreto" - contemplou, sobretudo, os autores e obras francesas anotadas pelo autor. No entanto, um olhar mais demorado sobre o Diário mostrou-nos aspectos diversos a serem explorados num projeto de maior amplitude que permitisse análises e interpretações que buscassem enxergar as anotações de Lima à luz da ideologia dominante versus perspectivas não hegemônicas. Em face dos prodigiosos comentários tecidos por Lima ao longo dos anos de escritura do Diário (1900-1921), que versam desde o comportamento de muitos de seus contemporâneos, observações de teor político e social, às reflexões acerca das teorias raciais, foi que decidimos dar continuidade a essa pesquisa em um projeto de mestrado, iniciado no segundo semestre de 2009.

Essa pesquisa partiu do exame minucioso do Diário Íntimo com a realização de um levantamento exaustivo dos nomes de pintores, filósofos, escritores, críticos, pesquisadores e historiadores brasileiros e estrangeiros citados pelo autor. Esse processo nos possibilitou observar a predominância de referências francesas, totalizando 41 autores. Esse número expressivo chama a atenção, especialmente quando o contrapomos com as demais referências quantitativas encontradas: 16 autores brasileiros, 8 portugueses, 7 alemães, 6 ingleses, 2 russos, além de mais 7 referências às personalidades de outros 
países - Itália, Prússia, Espanha, Grécia, Ucrânia e Polônia. Esse levantamento inicial comprovou que o Diário Íntimo, de fato, apresentava uma fonte valorosa de referências francesas.

Os resultados dos levantamentos efetuados foram organizados em tabelas, onde constaram não apenas as personalidades francesas, como também as obras, os lugares, as palavras, as revistas e os jornais franceses referidos em Diário Íntimo. A distribuição desses dados em tabelas quantitativas e qualitativas proporcionou uma visualização detalhada das referências presentes nessa obra, conferindo maior materialidade à pesquisa.

Consideramos relevante efetuar o levantamento de todas as obras citadas justamente para observar se, também no tocante aos volumes, havia um maior número de referências aos títulos de autores franceses. Aqui, obtivemos o número de 19 obras francesas, em contraposição verificamos o total de 20 dos demais países, sendo que 6 são de autores brasileiros, 3 de portugueses e as demais são de autores russo, inglês, espanhol e alemão. Mais uma vez, o número de obras francesas configurou-se superior às das demais nacionalidades, inclusive de obras brasileiras. Dos livros mencionados no Diário, observamos que grande parte compunha a biblioteca pessoal de Lima Barreto.

A fim de situar dentro do contexto e do período em que fizeram parte, elaboramos fichas bio-bibliográficas de cada personalidade francesa identificada. Tais fichas nos ajudaram a compreender a visão de Lima sobre o universo francês, pois, na medida em que conhecíamos as personalidades referidas, pudemos analisar mais claramente os comentários que ele teceu ao longo do Diário Íntimo. 
Elaboramos também uma biografia minuciosa do autor com a finalidade de observar sua formação intelectual, assim como sua atuação nos meios histórico, político e literário nos quais se inscreveu. O contato com a trajetória de vida desse autor permitiu-nos melhor compreender os fatos por ele anotados nas páginas íntimas, marcadas pelo aspecto confessional.

Efetuamos ainda um derradeiro levantamento que reuniu todas as anotações referentes às reflexões de Lima acerca das teorias raciais, com a intenção de observar a constituição e conteúdo desse tipo de comentário. A reunião dessas notas possibilitou-nos enxergar que ora Lima trouxe para 0 Diário os postulados raciais da perspectiva científica, comentando os argumentos usados para construí-los, ora expressou a forma que se viu e vira outros de igual condição racial serem atingidos pela ciência, ora ainda mostrouse encerrado entre o discurso legitimador das teorias científicas e a observação do comportamento de negros e mestiços.

Verificamos que o Diário Íntimo possui três edições, a primeira data de 1953 (pela editora Mérito), a segunda de 1956 e a terceira de 1961 (ambas pela editora Brasiliense), todas organizadas por Francisco de Assis Barbosa. Após efetuar uma análise comparativa das edições, escolhemos trabalhar com a segunda, que é idêntica à terceira, pelo fato desta apresentar maior riqueza de notas explicativas, se comparada com a primeira edição, elaboradas por Francisco de Assis Barbosa com a colaboração de Antônio Houaiss e M. Cavalcanti Proença. Esta segunda edição apresenta ainda um período mais longo de escritura do Diário - 1900 a 1921, ao passo que a primeira compreende o período de 1903 a 1921, além de não contemplar os anos de 1906, 1910 e 1914, anos estes presentes na edição de 1956. De acordo com a 
nota prévia da segunda edição, foram acrescentados esboços de possíveis romances, dos quais muitos não chegaram a ser desenvolvidos pelo autor. É válido ressaltar que, ao fim da segunda edição, consta a primeira versão incompleta de Clara dos Anjos (1904), já ao final da primeira, temos os apontamentos de Diário do Hospício, fragmentos de Cemitério dos Vivos (capítulos I - V) e o inventário da biblioteca de Lima Barreto organizada por ele mesmo e batizada de "Coleção Limana". Os manuscritos das páginas que compõem o Diário Íntimo, bem como da primeira versão incompleta de Clara dos Anjos e demais escritos do autor encontram-se na divisão de manuscritos da Biblioteca Nacional do Rio de Janeiro.

Diante dos resultados dos extensos levantamentos realizados, orientados a partir de um ponto de vista metodológico fortemente analítico, passamos à investigação dos estudos acadêmicos acerca da obra de Lima Barreto. Nesse ponto, procuramos conhecer os trabalhos a respeito especificamente do Diário Íntimo a fim de nos desviarmos das perspectivas já trabalhadas e orientarmos nossa dissertação de modo diverso.

Verificamos haver uma dissertação de mestrado e uma monografia de iniciação científica cujo corpus privilegiado para análise tratou-se do Diário Íntimo. A dissertação de Martins (2008) intitulada Diário Íntimo - documento da memória, criação estética - uma dupla leitura pautou-se na ideia de que "há trabalho estético e elemento ficcional no que poderia ser exclusivamente testemunho e documento" (Ibid., p. 14) nas páginas do Diário. Concebeu essas notas como prolongamento do projeto literário limabarretiano. Desse modo, considerou o Diário Íntimo uma obra criativa capaz de revelar intersecções entre literatura e contexto social. A partir da experiência subjetiva individual 
registrada nas notas íntimas, a autora procurou depreender aspectos coletivos da realidade brasileira à época em que viveu o autor. Embora tenha se proposto a analisar o Diário Íntimo, consagrou a maior parte do trabalho à análise dos romances de Lima, colocando em segundo plano as páginas diarísticas. Por sua vez, a monografia de Knabben (2010) - "O diário de Lima Barreto - da intimidade à historicidade e à literariedade" - de caráter predominantemente mais expositivo do que analítico, concentrou-se em descrever, ano a ano, as anotações do Diário. Apontou para o registro de fatos históricos e atentou ainda para trechos esteticamente poéticos que surgem em meio aos relatos quotidianos.

No que tange aos demais estudos críticos consultados a respeito de Lima Barreto, destaca-se o caráter histórico sociológico permeando muitas das interpretações, a exemplo dos trabalhos de Antonio Arnoni Prado (1976), Carmen Lúcia N. de Figueiredo (1995/ 1998), Maria Cristina T. Machado (2002), Carlos Henrique Gileno (2010), Robert John Oakley (2011) e Luiz Silva (2005/ 2011). Prado (1976, p. 12) concentrou seu estudo nos escritos de Lima de 1904 a 1922, atentando, sobretudo à produção jornalística; com a intenção de observar "como se formou em Lima Barreto uma posição crítica em face da literatura oficial de sua época, de que modo ela se manifestou e até que ponto contribuiu para abalar as bases tradicionais de uma literatura em transição para o moderno". Figueiredo focalizou três romances de Lima: Recordações do escrivão Isaías Caminha, Triste fim de Policarpo Quaresma e Vida e morte de M. J. Gonzaga de Sá, para refletir sobre questões referentes à vida e à obra no que diz respeito ao alcance social da luta desse autor. Machado (2002, p. 07) examinou "as representações sobre a modernidade brasileira que aparecem na 
obra de Lima Barreto, explorando a literatura como fonte e forma específica de conhecimento do mundo social". Gileno buscou demonstrar como os romances de Lima figuram pioneiramente como crítica ao racismo científico, para isso lança mão das seguintes obras - Clara dos Anjos, Recordações do escrivão Isaías Caminha e Numa e a Ninfa. Oakley buscou iluminar a questão "o conteúdo vale mais que a forma", tida como fundamental para Lima, examinando sua prosa e também observando a bagagem cultural europeia por meio das leituras feitas pelo autor. Silva discutiu a problemática racial, em seu primeiro trabalho (2005) focalizou as trajetórias de Lima Barreto e Cruz e Souza mostrando que o sujeito étnico percorre os textos desses autores o que gera uma tensão com o discurso racial vigente. Em seu segundo trabalho (2011), analisou a produção limabarretiana buscando mostrar a atualidade dos problemas assinalados por Lima ainda no início do século XX.

Não podemos deixar de sublinhar os estudos norteados pelo ponto de vista psicanalítico, como os de Luciana da Costa Ferreira (2007) e Luciana Hidalgo (2008). O primeiro trabalho objetivou realizar uma reflexão acerca do conceito de memória, tendo como percurso investigar a construção da figura de um escritor por parte dele próprio e da crítica, sendo assim teve como foco a análise da memória de Lima Barreto, investigando as estratégias usadas por esse autor para construir sua imagem. $O$ segundo trabalho, ganhador do prêmio Jabuti (2009), Hidalgo pautou-se no Diário do Hospício de modo a aproximar literatura e loucura para construir o conceito de "literatura da urgência"; analisou as especificidades do fazer literário no confinamento do hospício.

Há ainda os trabalhos que privilegiaram as escolhas literárias de Lima 
Barreto, tais como forma, temáticas e linguagem; nesse sentido, destacam-se os trabalhos de Osman Lins (1976), Andrea Saad Hossne (1999), Zélia Nolasco Freire (2005) e Mauricio Silva (2006). Lins focalizou os espaços dos escritos limabarretianos, teorizou sobre o espaço romanesco atentando para as relações entre personagem e espaço. Hossne procurou apreender as especificidades da forma do romance em Lima Barreto, considerando sua posição marginal na sociedade e na literatura brasileira e o seu projeto literário, solidário aos excluídos; contemplou todos os romances desse autor. Freire concentrou-se em analisar a linguagem usada pelo escritor Lima Barreto, ressaltando a importância dessa figura para as letras nacionais, mostrou como sua obra e postura foram importantes para a sustentação do ideário modernista que viria a tona na Semana de 1922. Silva buscou investigar as várias tendências literárias ao longo do período de transição do século XIX para o seguinte, focalizou especialmente duas vertentes - a chamada literatura oficial, conservadora e a chamada literatura pré-modernista; sendo Coelho Neto representante eleito para o estudo da primeira vertente e Lima Barreto para a segunda. A partir da análise de traços estruturais como linguagem, estrutura narrativa e temas das obras ficcionais desses dois autores, pretendeu apontar semelhanças e divergências das opções literárias de Coelho Neto e Lima Barreto.

Outros estudos focalizaram a representação da cidade do Rio de Janeiro nos escritos do autor carioca, como o de Beatriz Resende (1993), que contemplou, sobretudo, as crônicas limabarretianas, nas quais observou aspectos históricos e sociais passados no Brasil e, especialmente, na cidade do Rio de Janeiro. 
Notamos, mais recentemente, pesquisas ainda em curso acerca do diálogo de Lima com os modelos franceses, como evidenciam os trabalhos apresentados em congressos de Walter Mendes Santos (2011) - "Temas stendhalianos e intertexto balzaquiano em Lima Barreto" - e de Milene S. de Almeida (2011) - "Lima Barreto lê Anatole France". Inscrevemos aqui nossa pesquisa, anteriormente mencionada, sobre essa temática das referências francesas de Lima Barreto, apresentada, em 2008, no Simpósio de Iniciação Científica promovido pela Universidade de São Paulo. Até aquele momento, os levantamentos realizados na biblioteca da FFLCH e em outras bibliotecas virtuais haviam confirmado a inexistência de trabalhos específicos sobre as leituras francesas ou em francês de Lima Barreto, fato que corroborou para a realização do projeto de iniciação científica. É válido frisar o modo como a matéria do Diário Íntimo figura em muitos dos trabalhos citados - tomada como complemento das análises pautadas primariamente em fontes literárias (romances, contos, crônicas, artigos), as páginas íntimas parecem escritosacessórios incorporados ao recorte principal.

Apresentadas as principais abordagens que nortearam os estudos da obra limabarretiana e, sobretudo, o tratamento conferido às notas íntimas, cabe explicitar que nossa pesquisa elegerá o Diário Íntimo como escrito-base, ou seja, corpus sobre o qual se fundamentará nosso estudo que o focalizará do ponto de vista formal do gênero diário. Assim procedendo, investigaremos de que modo se constituiu essa obra, com o intuito de levantar hipóteses interpretativas no que tange às motivações, necessidades e préstimos das páginas íntimas para esse autor. Visamos a refletir, no plano literário, a respeito do olhar de Lima voltado para os modelos estrangeiros, especialmente as 
referências francesas e, no plano social, acerca de sua condição mestiça a partir dos relatos de situações cotidianas e comentários perspicazes que demonstram a forma como a sociedade, naquele momento, encarava os mestiços, do ponto de vista limabarretiano. Eis aí descrito o recorte que orientará nosso estudo.

Temos como objetivo geral avaliar a atuação desse autor no âmbito dos estudos literários, considerando que sua obra se insere numa tradição literária da cultura europeia "branca", que ele ao mesmo tempo parece endossar e, em alguns pontos - de modo vanguardista - também transformar. Como as notas presentes no Diário tangem também aspectos históricos e sociais de seu tempo, será imprescindível transitar não só pela literatura, mas também pela antropologia e pela história a fim de tentar dar conta dos diálogos ativos e críticos estabelecidos por Lima com a tradição francesa sem perder de vista a realidade histórico-social brasileira.

A fim de atingir nossos objetivos, organizamos a dissertação em três capítulos. O primeiro capítulo - "O Gênero Diário: A Sensação na Origem da Razão" -, inicialmente, perfará o caminho que antecedeu a escrita intimista, os fatores que impulsionaram o desenvolvimento do gênero diário, sua origem, tipicidade, motivações que levam alguém a se servir de um "diário íntimo". Tratará de apresentar os traços estéticos que caracterizam esse tipo de diário, fortemente marcado pela presença daquele que o escreve. Utilizaremos para isso bibliografia específica, na qual se destaca os nomes de Girard (1963), Didier (2002), Lejeune (1996), Gusdorf (1991) e Simonet-Tenant (2004) ${ }^{1}$.

\footnotetext{
${ }^{1}$ Das referências bibliográficas de obras francesas, adotamos as edições em português quando já constam no mercado editorial, das referências ainda não traduzidas, realizamos a tradução mantendo, em nota de rodapé, o texto original.
} 
Verificaremos os diários mais representativos de matriz francesa que contribuíram para a difusão da escrita intimista conferindo ao diário status de gênero literário. Não deixaremos, no entanto, de destacar a ocorrência de diários na literatura brasileira, especialmente, ao longo do período de vida de Lima Barreto. Nesse bojo, será importante distinguir "diário íntimo" de autobiografia, a fim de marcar as particularidades de um e outro gênero. Em seguida, passaremos a observar a constituição material do Diário Íntimo de Lima Barreto, assim batizado pelo organizador das notas íntimas e também biógrafo do autor, Francisco de Assis Barbosa. A análise transitará a todo o momento entre os fatos anotados por Lima e as notícias biográficas colhidas principalmente pelo seu biógrafo, acima referido. Baseados em sua biografia, refletiremos acerca das motivações que levaram o autor a escrever páginas íntimas e sobre o uso que delas fez. Por fim, tendo em vista a caracterização do gênero diário íntimo, avaliaremos em que medida Lima respeitou as especificidades desse gênero e buscaremos entrever o caráter "extravagante" do Diário, assim qualificado pelo autor.

O objetivo geral desse primeiro capítulo é pinçar os temas recorrentes dignos da atenção de Lima, no sentido de identificar as opiniões reveladoras do homem Lima Barreto. Privilegiaremos dois desses temas, objetos de análise nos capítulos seguintes: as referências francesas e as reflexões sobre a questão racial. Temos como objetivo específico pensar no modo como se constituiu o eu confessional, a partir de seus projetos, desejos, fraquezas e sonhos expressos nas páginas diarísticas.

Iniciaremos o segundo capítulo - "O Rio de Janeiro no limiar do século XX - Lima Barreto em Cena" - descrevendo os cenários por onde circulara o 
autor carioca. Caracterizaremos a cidade do Rio de Janeiro nos idos do início do século $\mathrm{XX}$, mostrando brevemente as reformas urbanísticas empreendidas nesse período, que visavam modernizar a capital nacional tornando-a semelhante às capitais europeias. Apresentaremos, em seguida, o repertório de leituras de Lima Barreto. Assim, citaremos os autores mais significativos das mais diversas nacionalidades, a fim de mostrar os assuntos pelos quais ele nutriu interesse. A partir disso, poderemos ver sua imagem enquanto leitor e a relação mantida com os modelos estrangeiros. Contribuirá para essa etapa, o cotejo das obras citadas no Diário com aquelas constantes na "Coleção Limana". Considerando os resultados de nossos levantamentos, sublinharemos as marcas francesas por meio dos dados concretos reveladores do diálogo estabelecido com essa matriz europeia. Dessas marcas, nos concentraremos na análise das referências literárias francesas. Atentaremos para o tipo de comentário tecido por Lima, se elogio, crítica, etc; a relação afetiva mantida com as obras francesas, a finalidade dessas leituras. Nesse ponto, buscaremos entrever os modelos que Lima se apropriou ou renegou, a favor ou contra o que ele se manteve levando em conta a posição de intelectual brasileiro olhando para o legado francês.

A base teórica que estruturará as interpretações a respeito dos diálogos estabelecidos com a tradição francesa provirá especialmente das obras de Carvalhal (2003) e Abdala Júnior (2007). No que concerne à presença francesa em nossa literatura, nos pautaremos nos trabalhos de Alcoforado (1982), Amaral (1996) e Passos (1996) que, embora não tratem de Lima Barreto, investigam as marcas francesas nas obras de outros escritores brasileiros.

Assim, o objetivo geral aqui é pensar na função das referências literárias 
francesas na literatura brasileira do século XIX que tanto ocupou nossa prosa e verso; sendo o objetivo específico, refletir sobre as posições sustentadas por Lima no plano intelectual com vistas em seu projeto literário. Dois textos limabarretianos serão fundamentais para observarmos o modo como concebia a literatura, são eles: "Amplius" e "O Destino da Literatura". À luz das concepções presentes nesses textos, discutiremos a respeito do projeto de elaboração do Germinal negro tal como explicitado no Diário, livro que seria a obra-prima do autor carioca.

Considerando a imagem de Lima delineada por ele mesmo no Diário, da qual se destaca a origem racial de negro, no terceiro capítulo - "Brasil: O Projeto de Nação para um Povo Mestiço" - discorreremos a respeito da constituição nacional pós independência, destacando a questão racial de nosso país e o esforço dos intelectuais em criar um projeto literário voltado para a realidade local. Exporemos as principais teorias raciais que nortearam as ações políticas no Brasil ao longo do início do século XX. Contemplaremos o impacto, usos e desdobramentos dessas teorias que mantiveram à margem dos centros de poder aqueles marcados pela cor negra. Desse modo, caberá aqui caracterizar social e antropologicamente negros e mestiços no Brasil do século XIX e início do XX, buscando situá-los no âmbito da sociedade brasileira à época referida. Analisaremos os comentários de Lima acerca da temática racial, que o implicava duplamente, visto ser um pensador social de seu tempo e pela origem mestiça da qual compartilhava. Nesse sentido, além dos traços temáticos, atentaremos para os traços formais da linguagem usada por ele para tratar do complexo e escorregadio problema da identidade nacional. É nossa intenção mostrar como Lima se vira atingido pelos postulados raciais e 
como vira outros dos seus serem igualmente afetados. Observaremos sua postura ambivalente decorrente do combate e crédito às teorias raciais, à medida que ora depreciou, duvidou dos dogmas científicos, ora se serviu deles para analisar sua família. Pautará o trabalho interpretativo, sobretudo, as obras de Ventura (1991), Schwarcz (1993), Sevcenko (2003) e Munanga (2004), estudiosos que, em resumo, discutiram a formação étnica e cultural do povo brasileiro nos primeiros anos da República.

Diante do exposto, o objetivo geral desse último capítulo é verificar a condição social do negro em nossa sociedade à época vivida por Lima com o intuito de melhor compreender as notas presentes no Diário. O fim específico é observar de que modo o eu limabarretiano se mobilizou nas esferas privada e pública, focando a circulação desse autor no trânsito social-pessoal e viceversa.

Por fim, na conclusão, arremataremos as análises alinhavadas em cada capítulo precedente, pontuando a visão de Lima sobre os temas abordados as referências francesas, seu projeto literário de escrever o Germinal negro, as teorias raciais, os rumos políticos concedidos à nação. É ainda nossa intenção aprofundar a presença do que chamaremos de eu confessional (faceta íntima), doméstico (faceta familiar) e social (faceta pública) em trânsito pelas páginas íntimas, atentando para as tensões decorrentes da postura ambígua desse autor, construída em virtude das crenças científicas de seu tempo conjugadas com o pensamento contestador de uma personalidade "extravagante". Tarefa desafiadora, posto que as contradições formam, em geral, tramas bem entrelaçadas. Cabe-nos, pois, segurar as pontas do fio e segui-lo. 
Capítulo I

O Gênero Diário: A Sensação na Origem da Razão

"Se essas notas forem algum dia lidas, o que eu não espero, há de ser difícil explicar esse sentimento doloroso que eu tenho de minha casa, do desacordo profundo entre mim e ela; é de tal forma nuançoso a razão de ser disso, que para bem ser compreendido exigiria uma autobiografia, que nunca farei. Há cousas que sentidas em nós não podemos dizer."

(Diário Íntimo) 


\section{O Gênero Diário: A Sensação na Origem da Razão}

Considerando nosso objeto de estudo - O Diário Íntimo de Lima Barreto, contemplaremos nesse primeiro capítulo a forma do gênero diário, caráter, por assim dizer, mais genuinamente literário desse trabalho. Privilegiaremos os aspectos formais desse gênero a fim de avaliar em que medida Lima respeitou suas características e/ ou se buscou construir seu diário de modo inédito.

No âmbito literário, os estudos acadêmicos dos gêneros revestem-se de especial importância, visto contribuírem para delineá-los de modo sistematizado, num primeiro momento, e, num segundo, consolidá-los concedendo aos mesmos direito e dignidade. Nessa esteira, Lejeune, ao refletir acerca dos estudos críticos sobre os gêneros, destacou:

O gênero repousa sobre pressupostos de permanência e autonomia. Implica, portanto, na crença em uma espécie de identidade, que pode ser produzida apenas por uma série de distinções e preceitos destinados ao mesmo tempo a isolar o gênero das demais produções e a hierarquizar e centrar o âmbito assim inscrito (LEJEUNE, 1996, p. 320, tradução nossa) ${ }^{2}$.

Observada por essa perspectiva, a descrição dos gêneros torna-se normativa, à medida que responde a um horizonte de expectativas quando olhamos para um texto. Entretanto, o fértil terreno da imaginação criativa, muitas vezes, entrelaça formas distintas desafiando as classificações previamente estabelecidas.

Apresentadas essas primeiras observações, cabe explicitar que 0

\footnotetext{
${ }^{2}$ Texto original: «Le genre repose sur des présupposés de permanence et d'autonomie. II implique donc la croyance en une espèce d'identité, qui ne peut être produite que par des séries de distinctions et de préceptes, destinés à la fois à isoler le genre des autres productions, et à hiérarchiser et centrer le domaine ainsi enclos »(LEJEUNE, 1996, p. 320).
} 
objetivo da primeira parte desse capítulo é caracterizar o gênero diário em sua relação com a tradição europeia. Não é tarefa fácil estudá-lo, dado a diversidade quantitativa e qualitativa dos diários - históricos, de bordo, de escritores, de adolescentes, etc. A flexibilidade desse gênero e a ausência de regras fixas talvez sejam algumas das condições propiciadoras da grande variedade de diários. Por essa razão, focaremos, sobretudo, o diário íntimo, espécie de subgênero do diário, ligado não apenas ao relato - poético, no caso dos diários literários - dos fatos cotidianos, mas também fortemente marcado pela questão autobiográfica.

Com o intuito de melhor compreender a constituição do diário íntimo, buscaremos perfazer o caminho que antecedeu o desenvolvimento da escrita intimista presente nesse tipo de diário, atentando para as condições que favoreceram o descortinar da intimidade.

\subsection{O Universo Particular das Páginas Íntimas}

Foi no período da Renascença (século $\mathrm{XVI}$ ) que avultaram as manifestações de individualismo, momento em que ressurgiram os estudos das ciências humanas, fazendo com que o homem voltasse o olhar para si, tomando-se como objeto e sujeito de observação. Nesse contexto, destacou-se o nome de Montaigne (1533-1592), fundador do gênero ensaio, autor que pautou todo conhecimento a partir de seu eu, transformando-o em objeto privilegiado de reflexão. Em seus textos ensaísticos, sua pena manteve-se livre, guiada pelo senso comum, misturou instinto com experiência, circulando pelos temas mais diversos e registrando experiências e reflexões extraídas do 
cotidiano. No século seguinte, acompanhamos a prefiguração dos diários modernos com a publicação da obra Pensamentos [Pensées] (1670) de Pascal (1623-1662), reunião de pensamentos que atestam os limites da razão humana diante do mistério da fé e da angústia da existência. Chegamos à exacerbação da exaltação do eu, no século XVIII, com as Confissões [Confessions] (1782) de Rousseau (1712-1778) que "[c]onfessando suas falhas morais, enfatizava sua honestidade e, ao mesmo tempo, criava um Jean-Jacques ideal, que podia falar diretamente, do fundo do coração, com o leitor ideal imaginado no texto" (DARNTON, 1986, p. 301). Rousseau tinha a intenção de alcançar a vida por meio da literatura, embora não tivesse mantido um diário, refletiu sobre a prática da escrita pessoal, prova disso verificamos nas linhas iniciais do primeiro livro de Confissões: "Quero mostrar aos meus semelhantes um homem em toda a verdade de sua natureza, e esse homem serei eu" (ROUSSEAU, [19 -], p. 13). Encontra-se aí esboçada a escrita da intimidade, de temática privada. Interessante notar que na biblioteca pessoal de Lima Barreto constavam as obras referidas desses três autores: Essai, de Montaigne; Pensées, de Pascal e Confessions, de Rousseau.

Acompanhemos, nas palavras de Girard, os fatores que gestaram a escrita intimista:

Seu nascimento resulta do encontro de duas correntes dominantes que impregnam o pensamento e a sensibilidade da época: de um lado a exaltação do sentimento e a voga das confissões, na esteira de Rousseau, do outro a ambição dos ideólogos de fundar a ciência do homem sobre a observação colocando na origem do entendimento a sensação, segundo Locke, Helvétius e Condillac (GIRARD, 1963, p. IX-X, tradução nossa) $)^{3}$.

\footnotetext{
${ }^{3}$ Texto original: «Sa naissance est le résultat d'une rencontre entre les deux courants dominants qui imprègnent la pensée et la sensibilité de l'époque : d'un côté l'exaltation du
} 
Com efeito, o diário se consolidou com o individualismo romântico, permeado pela temática da solidão do homem, a saudade, a melancolia temas que exprimem, por excelência, o estado de alma daquele que escreve. Importava para o poeta romântico percorrer a experiência do sujeito; conquistou-se, assim, o direito de desvelar abertamente os sentimentos mais íntimos.

Olhando em conjunto o movimento romântico nas literaturas do Ocidente da Europa e nas que Ihe são tributárias, como a nossa, temos a impressão de um novo estado de consciência, cujos traços porventura mais salientes são o conceito de indivíduo e o senso da história. Por isso, individualismo e relativismo podem ser considerados a base da atitude romântica, em contraste com a tendência racionalista para 0 geral e o absoluto (CANDIDO, 2007, p. 341).

Com a estética romântica, abandonou-se o culto das tradições grecoromanas, os temas universalistas, comuns a todos, corolário da literatura clássica "afirmando em contraposição o concreto espontâneo, característico, particular" (Ibid., p. 333). Passava-se para o primeiro plano o culto do eu que, a partir de então, começou a tornar-se público. Chateaubriand (1768-1848), escritor francês, nomeou acertadamente esse estado de alma de vague-àl'âme, indicando o estado que

[...] precede o desenvolvimento das paixões, quando nossas faculdades, nascentes, ativas, mas reconcentradas, só se aplicaram sobre elas próprias, sem alvo nem objetivo. Quanto mais os povos se adiaram na civilização, mais aumenta esse estado de vago das paixões (CHATEAUBRIAND apud CANDIDO, Id., p. 296).

sentiment, et la vogue des confessions, dans le sillage de Rousseau, de l'autre l'ambition des idéologues de fonder la science de l'homme sur l'observation, en plaçant à l'origine de l'entendement la sensation, à la suite de Locke, Helvétius et Condillac » (GIRARD, 1963, p. IX$\mathrm{X})$. 
No Brasil, a estética romântica chegou mais tarde por meio de um grupo de intelectuais brasileiros, cujo nome mais representativo foi o de Gonçalves de Magalhães (1811-1882) que, após temporada em Paris (1833-1836), trouxe para cá novas orientações literárias. Em termos sociais, no final do século XVIII, por aqui, vigorava o sistema monárquico conservador, apoiado no sistema latifundiário, no escravismo e na economia de exportação.

Na França pós Revolução (1789), assistiu-se à derrocada da nobreza e à crescente ascensão da classe burguesa. Vejamos os meandros desse contexto à época nas palavras de Bosi:

O primeiro e maior círculo contorna a civilização no Ocidente que vive as contradições próprias da Revolução Industrial e da burguesia ascendente. Definem-se as classes: a nobreza, há pouco apeada do poder, a grande e a pequena burguesia, o velho campesinato, o operariado crescente. Precisam-se as visões da existência: nostálgica, nos decaídos do Ancien Régime; primeiro eufórica, depois prudente, nos novos proprietários; já inquieta e logo libertária nos que vêem bloqueada a própria ascensão dentro dos novos quadros; imersa ainda na mudez da inconsciência, naqueles para os quais não soara em 89 a hora da Liberdade-lgualdadeFraternidade (BOSI, 2006, p. 91).

Segundo Didier (2002), o desenvolvimento do gênero diário pareceu estar ligado à constituição da classe burguesa. Impulsionado por um ideal laico e materialista, portador de uma ideologia do mérito, o burguês mostrou-se preocupado em usar metodicamente sua vida, e o diário pode dar conta dessa preocupação. Contribuiu para sustentar essa hipótese o fato de não se terem encontrado diários nem na Antiguidade, nem na Idade Média, o que não quer dizer que não se praticava nessas épocas a escrita diarística, visto haver sempre a dificuldade de conservá-los. 
[...] não existe diário antes do século XV; a partir dessa data, evolui da simples crônica para um texto onde a individualidade do autor é muito mais presente na medida em que a classe burguesa conquista um poder crescente, um lugar cada vez maior no patrimônio cultural (DIDIER, 2002, p. 47, tradução nossa $)^{4}$.

O Romantismo, os direitos humanos, a igualdade de direitos civis levaram a uma transformação radical da noção de pessoa, na dobra do século XVIII para o XIX, aspectos que contribuíram decisivamente para fertilizar o gênero diário íntimo, fruto do reconhecimento da importância da vida privada.

O novo papel do Estado, que passou cada vez mais a regular o espaço social anteriormente entregue à comunidade, aliado às Reformas religiosas, que passaram a exigir do fiel intensa devoção interior, mais o desenvolvimento da alfabetização e a difusão da leitura graças à imprensa foram fatores que, combinados, permitiram ao indivíduo emancipar-se dos antigos laços que o prendiam ao coletivo, propiciando, assim, a conquista da intimidade individual. Com efeito, a sociedade industrial modificou a relação do sujeito com seus semelhantes, a partir daí o que tivemos foi uma vasta população anônima. Nesse cenário, o diário íntimo passou a exprimir a interrogação desse sujeito em face dessa nova organização social.

O desejo de esclarecimento interior, combinado com o temor do desperdício, suscita aqui uma prática que não subentende nenhum diálogo com o Criador. É em função do olhar sobre si mesmo, e dos olhares dos outros e do mundo, que se estrutura um exame permanente, obcecante (PERROT, 1991, p. 457).

As novas formas de religião surgidas a partir da Reforma Protestante

\footnotetext{
${ }^{4}$ Texto original: « [...] le journal n'existe pas avant le XVè siècle; à partir de cette date, il évolue de la simple chronique, à un texte où l'individualité de l'auteur est beaucoup plus présente, à mesure que la classe bourgeoise conquiert un pouvoir croissant, une place de plus en plus grande dans le patrimoine culturel » (DIDIER, op.cit., p. 47).
} 
(século XVI) desenvolveram maneiras de devoção íntima, como o exame de consciência. A prática da escrita solitária fatalmente levaria à reflexão subjetiva - combinação que parece acordar-se perfeitamente com as exigências do Protestantismo, favorável à redução de intermediários entre o crente e Deus. Assim, livre da prática da confissão, o próprio homem teria o poder de julgarse, fator propício ao intimismo. Nessa perspectiva, a escrita cotidiana cumpriria - papel análogo àquele da confissão. Aqui gostaríamos de sugerir uma analogia: do mesmo modo que a presença do outro pesa em nossa conduta, especialmente nos momentos de exposição da intimidade, caso do ato confessionário, sobre a escrita pesará igualmente o constrangimento dos sentimentos interiores.

Assinalamos que na França o Protestantismo não teve grande relevo, foi propagado nesse país pelos suíços Benjamin Constant (1767-1830) e Amiel $(1821-1881)^{5}$ - célebres diaristas.

A escrita e a leitura individual articuladas permitiram ao indivíduo a reflexão solitária contribuindo decisivamente para o surgimento das escritas do eu que tiveram como suporte, de um modo geral, os diários, as cartas e as confissões em voga no século XVIII.

O desenvolvimento da alfabetização e a difusão da leitura [...] constituem, portanto, com diferenças e variantes, um dos fatos principais que contribuem para modificar a ideia que o homem ocidental tem de si mesmo e de sua relação com os outros (CHARTIER, 1991, p. 122).

\footnotetext{
${ }^{5}$ Benjamin Constant foi escritor e político. Atuante no setor político francês de 1815-1830. Escreveu diversas obras versando sobre a liberdade individual e princípios da política. HenriFrédéric Amiel foi filósofo, poeta e crítico. Atuou como professor de Estética e Literatura na Universidade de Genebra, onde depois passou à cadeira de Filosofia. Embora tenha publicado vários estudos no campo literário, ficou conhecido pelas reflexões contidas em seu diário.
} 
Didier (op. cit., p. 140-141) sublinhou que o diário íntimo desenvolveu-se exclusivamente nos países e nas épocas em que se praticou a leitura silenciosa - maneira de ler que possibilita ao leitor interiorizar imediatamente a matéria lida. Por sinal, tal tipo de leitura resultou do advento da sociedade industrial e capitalista. No entanto, paradoxalmente, o diário íntimo pode ser ditado, como foi o caso de trechos do diário de Stendhal (1783-1842) e de Charles Du Bos (1882-1939). A leitura intimista propiciou o sucesso de obras como A Nova Heloisa [La Nouvelle Héloïse] ${ }^{6}$ e Paulo e Virginia [Paul et Virginie], à medida que o leitor passou a identificar-se com a narrativa e a sentila mais intensamente por meio da leitura silenciosa. Nesse bojo, o sucesso do diário deveu-se ao grande número de leitores interessados em ler esse tipo de obra. De fato, o gosto pela descoberta do indivíduo mobiliza o leitor que busca verdades a respeito de quem escreve, já que "[n]o diário o escritor faz-se ator, e expõe publicamente o reino do privado" (AGUIAR; MEIHY; VASCONCELOS, 1997, p. 165).

Em suma, foi o individualismo, produto do cristianismo e da prática capitalista, que fecundou, no início do século XIX, o gênero que nos interessa. Esses fatores conjugados propagaram as escritas do eu.

Dois grandes textos exemplares precederam a constituição do gênero diário: o Journal do francês Gilles de Gouberville (1521-1578) e o Journal do inglês Samuel Pepys (1633-1703). Do primeiro, foram encontrados os manuscritos correspondentes ao período de 1549 a 1562, nos quais o autor registrou os fatos mais simples da vida contemplando espaços e gestos

\footnotetext{
${ }^{6}$ Essa obra de Rousseau parece ter sido o maior best-seller do século XVIII, a procura por exemplares ultrapassou o volume impresso disponível para venda, fato que levou alguns livreiros a alugar o livro.
} 
privados. O segundo, mais frequentemente citado como primeiro exemplo de grande diário pessoal, abarca cerca de nove anos - de janeiro de 1660 a maio de 1669. Nesse diário constam anotações referentes à vida privada de Pepys, bem como crônicas do cotidiano de Londres dessa época: "[t]rata-se já de um diário íntimo e autobiográfico, muito à frente do similar francês [o de Gouberville] da mesma época" (CHARTIER, op. cit., p. 355).

A partir do século $\mathrm{XV}$, com o acesso mais facilitado ao papel, a escrita cotidiana tornou-se possível. As origens do diário íntimo datam da passagem do final do século XVIII - início do XIX. Foi por essa época, por volta de 1800, na França, que o diário se configurou enquanto gênero literário, sendo que as primeiras publicações dataram de 1850, sempre póstumas. Os primeiros escritores de diário tinham a ambição de compreender as operações do espírito, alcançar as relações do físico e do moral e melhor conhecer o homem: "[a] observação interior transforma-se imperceptivelmente em exame de consciência" (GIRARD, op. cit., p. X, tradução nossa) ${ }^{7}$.

Seguindo Girard (op. cit.), cronologicamente, na França, sucederam-se três períodos distintos na história do diário íntimo. O primeiro vai de 1800 a 1850/ 60, momento em que os diaristas mantêm seus diários para si, ou seja, não cogitam publicá-los, pois encaravam esse tipo de escritura como conhecimento de si e do mundo. Fizeram parte dessa primeira geração (18001820): Joubert (1754-1824), Maine de Biran (1766-1824), Stendhal (1783-1842) e Benjamin Constant todos nascidos no século XVIII e que, de algum modo, vivenciaram a experiência da Revolução. É preciso lembrar que coube a esses

\footnotetext{
7 Texto original: «L'observation intérieure se transforme insensiblement en examen de conscience » (GIRARD, op.cit., p. X).
} 
autores criar o modelo de diário íntimo, pois, até então, não havia uma forma delineada de expressão íntima usando como suporte um diário. Compuseram a segunda geração, que escreveu ao longo de 1830-1860, Alfred de Vigny (17971863), Delacroix (1798-1863), Michelet (1798-1863), Maurice de Guérin (18101839) e o mais jovem dentre eles, Amiel. Estes conheceram as obras dos autores precedentes, contudo, exceto Amiel, não chegaram a conhecer os diários. O segundo período dessa cronologia data de 1860 a 1900/ 10, momento em que fragmentos dos diários dos autores precedentes já haviam sido publicados. Assim, embora os diaristas desse segundo período, salvo algumas exceções, não pensassem ainda em entregar seus diários ao público, não podiam mais ignorar que viriam a ser publicados. $O$ terceiro período estende-se de 1910 aos nossos dias, a partir daqui os próprios autores entregam seus diários à publicação.

Foi a partir de 1910-20, que o diário íntimo tomou definitivamente a forma de gênero reconhecido como tal, à medida que partes dos diários vieram à luz por meio de publicações parciais, ainda que sempre aproximadas ou pouco rigorosas. Com efeito, foi por meio da publicação dos diários que o gênero se constituiu, ganhando formato, permanência e autonomia de gênero literário, embora, de acordo com Lejeune, pese ainda certa desconfiança literária em relação a esse gênero, visto o diário ser antes de tudo constituído por matéria trivial, que toma diretamente o instante narrado sem reflexão acabada, colocando-se, portanto, ao alcance de todos.

Cabe aqui destacar alguns diários mais representativos que contribuíram para a divulgação do gênero. Foi o caso da publicação do diário dos irmãos Goncourts - Edmond (1822-1896) e Jules-Alfred (1830-1870), escrito de 1851 
a 1896, publicado em seis tomos por Figaro Ilustré a partir de 1885; e o exemplar diário de Amiel escrito ao longo de quarenta e três anos, contabilizando mais de 16000 páginas manuscritas, publicado após sua morte.

O Brasil, ao menos até o início do século XX, registrou número ínfimo de autores que se debruçaram sobre a prática dessa forma de escritura. Verificamos nos acervos da biblioteca da FFLCH a existência de dois diários escritos anteriormente ao período abarcado pelo Diário Íntimo de Lima Barreto que se estendeu de 1900 a 1921. O primeiro é o Diário Íntimo de José Vieira Couto de Magalhães (1837-1898), monarquista liberal formado pela Faculdade de Direito de São Paulo. Dedicou-se à carreira política e empresarial, destacando-se como empresário das vias de comunicação. Governou as províncias de Goiás, Pará e Mato Grosso ao longo da década de 1860, além de ter sido presidente da província de São Paulo em 1888. Couto de Magalhães dedicou-se também à literatura, sua obra de maior destaque foi $O$ Selvagem (1876), na qual o autor expôs suas principais ideias sobre o processo de civilização dos índios.

Encontram-se, na biblioteca referida, dois exemplares do diário de Couto de Magalhães, cada um referente a períodos distintos. O exemplar organizado por Maria Helena P. T. Machado (1998), descoberto por acaso no Arquivo do Estado de São Paulo, corresponde a um período de anotação bastante curto, de 1880 a 1881, com notas dispersas nos anos seguintes até 1887 . Esse diário é composto por dois cadernos, sendo que cada um divide-se em duas seções. As anotações foram escritas em português, havendo algumas curiosamente grafadas em tupi; ao passo que as entradas (dias) foram registradas em inglês. Vale dizer que o autor encontrava-se em Londres nesse período. No que 
concernem aos assuntos abordados, observamos notas referentes aos acontecimentos do dia-a-dia, aos sonhos, aos negócios, aos relacionamentos e às reflexões do autor registradas em tom intimista e espontâneo. O outro exemplar foi publicado pela Coleção da Revista de História (1974) sob a direção do professor Eurípedes Simões de Paula, e contempla os anos de 1887 a 1890. Esse diário trata-se de um caderno de 132 páginas, não numeradas, todas preenchidas com anotações em letras grandes e espaçadas. As datas aqui também foram escritas em inglês. Segundo Bandecchi, prefaciador dessa edição do diário de Couto de Magalhães, "percebe-se que era hábito seu tudo anotar, registrar, comentar e até escrever pequenos lembretes, de forma ordenada. Hábito ou necessidade, devido à 'má memória' que confessa ter" (MAGALHÃES, 1974, p. 7-8). Por essa razão, talvez haja outros cadernos com registros desse autor ainda inexplorados ou que se perderam com o tempo. Não descartamos ainda a possibilidade da família ter barrado a divulgação de outros diários, em virtude das revelações de foro íntimo.

O outro diário encontrado é de autoria de Joaquim Nabuco (1849-1910), importante homem político dos primeiros anos da República. Obstinado pela causa escravista, fundou em 1880 a Sociedade Brasileira contra a Escravidão, cujo objetivo era incentivar a propaganda e a agremiação dos abolicionistas. Além da política, Nabuco dedicou-se também ao jornalismo e às letras.

Seu diário foi publicado em dois volumes, organizado por Evaldo Cabral de Melo: o primeiro referente ao período de 1873 a 1888 e o segundo, aos anos de 1889 a 1910, ano de sua morte. O manuscrito consiste em torno de trinta agendas, além de mais de 3800 folhas soltas. Nessas páginas 
encontramos notas que registram tudo que interessava à existência prática, afetiva e intelectual do autor. Os registros se davam quase diariamente, sendo que o formato visual desse diário assemelha-se ao de uma agenda. As palavras de Melo dimensionam esse projeto do autor de $O$ Abolicionismo: "Os diários de Nabuco são muito mais do que um diário factual, exceto, como veremos, nos anos de ativismo abolicionista, e menos do que um diário íntimo, salvo certas expansões privadas que não são frequentes" (NABUCO, 2005, p. 12). Destacam-se as notas referentes às impressões de leituras, às reflexões sociológicas feitas por Nabuco, além do hábito de anexar aos seus escritos, recortes de jornal.

Contemporâneo de Lima Barreto, o escritor maranhense Humberto de Campos (1886-1934), cuja obra é extensa e variada, composta, sobretudo, por crônicas e contos humorísticos, escreveu também um diário. Figura popular à época, membro da Academia Brasileira de Letras (1920), sua obra de maior destaque foi Memórias (1933). O diário de Campos, chamado Diário Secreto, foi publicado pela revista $O$ Cruzeiro, passados quinze anos de sua morte, respeitando a recomendação por ele deixada. Nessa primeira edição, a revista reservou-se o direito de censurar as notas demasiadamente contundentes. Posteriormente, a editora $O$ Cruzeiro publicou integralmente o diário de Campos em dois volumes - o primeiro referente aos anos de 1915, 1917, 1928 e 1929; e o segundo abarcou o período de 1930 a 1934.

Ao folhear esses volumes, notamos que o autor manteve certa regularidade cotidiana ao longo dos anos de escritura, efetuando alguns saltos de três a quatro dias entre cada entrada. Nessas notas, encontramos registros de suas atividades diárias, leituras realizadas, reprodução de diálogos, 
telegramas recebidos, poemas. A extensão de cada entrada variou, em geral, de meia a duas páginas. Observamos que Campos concentrou-se em escrever muito mais sobre os outros do que sobre si, pois raramente expôs seus sentimentos e desejos íntimos. Quando falou de si, na maior parte das vezes, o fez de forma louvável, rememorando elogios e galanteios recebidos.

A essa produção diarística se soma o diário a duas mãos de Patrícia Galvão (1910-1962), a chamada Pagu, e o modernista Oswald de Andrade (1890-1954). Caracterizado por anotações esparsas num caderno com 68 páginas escritas, não obedecendo a ordem cronológica, esse diário estendeuse de 24 de maio de 1929 a 2 de junho de 1931, contendo pistas biográficas da tumultuada relação amorosa entre Pagu e Oswald; em meio às notas há ainda poemas, epigramas e desenhos (CAMPOS, 1982, p. 62).

Posterior ao diário de Lima, acrescente-se nessa esteira o Diário Crítico de Sérgio Milliet (1898-1966), antologia em dez volumes, que recobrem os anos de 1940 a 1956. Nesses volumes constaram críticas, artigos, ensaios e anotações pessoais desse homem que foi escritor, crítico de arte, sociólogo, professor, tradutor e pintor. A publicação foi organizada por ele próprio; o primeiro volume veio à luz em 1944, e o último, em 1959. Passados vinte e dois anos, essa obra foi reeditada, com introdução valiosa de Antonio Candido. Embora Milliet não registrasse diariamente suas notas, verificamos reflexões bem desenvolvidas ao longo das páginas de seu diário. Acerca do teor desse diário, Candido descreveu:

As datas são as únicas divisões, a dimensão dos escritos varia de algumas linhas a muitas páginas, e por todos os volumes corre uma reflexão densa que passa de um assunto a outro, vai da pintura à política, da poesia ao preconceito racial, da 
sociologia à confissão, da notação fugaz ao romance (MILLIET, 1981, p. XVI).

Conforme nossas pesquisas indicaram, de fato, no Brasil, a escritura confessional em forma de diário, ao menos até meados do século $X X$, é algo inexpressivo em nossa história literária.

\subsection{Traços Estéticos do Diário Íntimo}

Um narrador em primeira pessoa que escreve sobre si e sobre fatos da realidade cotidiana, mantendo certa periodicidade, são características fundamentais na composição do diário íntimo. O diarista lembra-se daquilo que aconteceu há algumas horas ou dias e relata, ou seja, a escrita supõe certo recuo em relação à ação. Como o próprio nome indica, o diário é escrito no diaa-dia, sendo a periodicidade a única regra sentida como tal pelo diarista que, em princípio, não obedece a nenhuma regra imposta, ele é livre para colocar o que quiser na ordem desejada, ou simplesmente sem nenhuma ordem. Sobre essa liberdade da escrita, Didier afirmou que o autor do diário é livre para tudo dizer. As limitações e a censura existem mais no nível moral que estético: "a ausência de regras estéticas fixadas previamente por uma arte poética permitirá um jogo mais livre dos mecanismos de escrita" (DIDIER, op. cit., p. 07, tradução nossa) $)^{8}$.

Atentando à periodicidade, cabe aqui uma exposição etimológica da palavra journal que, de acordo com Simonet-Tenant (2004, p. 15-16), designa ao mesmo tempo o cotidiano da imprensa e uma prática de escrita pessoal,

\footnotetext{
${ }^{8}$ Texto original: «l'absence de lois esthétiques fixées à l'avance par quelque art poétique permettra un jeu plus libre des mécanismes de l'écriture » (DIDIER, op.cit., p. 07).
} 
significante que remete à relação da vida pública ou da vida privada. Em português, não há essa coincidência entre as denominações jornal e diário, salvo se lembrarmos dos nomes de alguns jornais brasileiros que se servem do vocábulo diário para compor seus títulos - caso do Diário de Notícias, Diário Popular, etc. Retornando ao vocábulo em francês journal, acompanhamos na análise de Simonet-Tenant que tal palavra apareceu na Idade Média como adjetivo - livre journal - registro onde um comerciante inscrevia dia-a-dia suas contas. Journal tornou-se substantivo no século XIV, significando o "livre d'enregistrement des actes" (1319) e, posteriormente, o "livre de prières quotidiennes" (1371). Desse modo, o journal distinguiu-se progressivamente em público e pessoal. No século XVII, adquiriu o sentido de "publicação periódica que dava conta dos fatos importantes de algumas áreas" (SIMONETTENANT, op. cit., p. 16, tradução nossa) $)^{9}$. Assim, o substantivo journal passou então a designar um tipo de publicação que hoje chamaríamos de revue spécialisée. A criação, em 1777, do Journal de Paris atestou o emprego do termo em seu sentido moderno e corrente de publicação quotidiana consagrada à atualidade. Em razão disso, no início do século XIX, acrescentou-se à palavra journal o adjetivo intime para designar a relação quotidiana de eventos ou de reflexões pessoais, privados e não destinados à publicação. Nesse contexto, surgiu outra problemática de ordem linguística: como nomear aquele que escreve um journal? Nomeá-lo de journaliste seria igualmente ambíguo. $\mathrm{O}$ uso do neologismo diariste reivindicado por Michèle Leleu, pouco a pouco ganhou espaço. Há ainda o termo intimiste que, no

\footnotetext{
9 Texto original: «publication périodique rendant compte des événements saillants dans certains domaines » (SIMONET-TENANT, op.cit., p. 16).
} 
entender de Girard (op. cit., p. 5), melhor denomina o escritor de diário íntimo.

No que concerne ao adjetivo intime, ainda segundo Simonet-Tenant, é originário do latim - intimus - superlativo correspondente ao comparativo interior, designa aquilo que está no mais profundo do ser, aquilo que permanece, em geral, escondido e secreto, o interior do interior. Foi o escritor francês André Gide (1869-1951) quem popularizou o adjetivo intime quando, em 1947, ao organizar a publicação de parte de seu journal, passagens referentes à sua esposa Madeleine, nomeou tais trechos de Journal Intime. Esses trechos haviam sido suprimidos da edição de seu Journal 1889-1939 publicado em 1939 pela Pléiade. Vale sublinhar que a consolidação do gênero diário se deu, especialmente, quando grandes escritores publicaram seus diários em vida. Nesse sentido, Gide contribuiu enormemente para conceder status ao gênero, organizando diversas publicações de partes de seu diário.

O caso de André Gide, enfim, cuja existência se estende de 1869 a 1951, mostra o exemplo mais significativo e completo dessa transformação do diário em gênero literário. Toda sua atividade de escritor, toda sua vida e pensamento giram, com efeito, em torno do Diário (GIRARD, op. cit., p. 90, tradução nossa) $)^{10}$.

O fato de nem toda prática de escrita diarística estar ligada à exploração de aspectos íntimos, levou alguns críticos como Philippe Lejeune e Jacques Lacarme a adotarem a denominação journal personnel. Outra denominação usada por Alain Girard e Georges Gusdorf é journal externe, para os diários do tipo crônica da atualidade, eco de solicitações exteriores, diário dos outros mais

\footnotetext{
${ }^{10}$ Texto original: «Le cas d'André Gide, enfin, dont l'existence s'étend de 1869 à 1951, offre l'exemple le plus significatif et le plus complet de cette transformation du journal en un genre littéraire. Toute son activité d'écrivain, toute sa vie d'homme et sa pensée pivotent en effet autour du Journal » (GIRARD, op.cit., p. 90).
} 
que de si mesmo.

As circunstâncias públicas ou privadas, múltiplas, diversas, repetidas ou semelhantes guiam o diarista por um caminho tão movediço quanto os dias que se sucedem. No diário íntimo, o autor é pessoalmente presente; em outras palavras, não procura dissimular-se sob nenhum véu. É justamente a observação focada na figura daquele que escreve o diário que o torna íntimo, privilegiando-se, desse modo, o lado privado da vida em relação à face exterior, pública. A interioridade é dominante, mesmo se são evocados acontecimentos exteriores, não é o que acontece fora que interessa ao diarista, mas sim a ressonância ou refração dos fatos em sua consciência. $O$ diário íntimo distingue-se dos demais diários pelo fato dos acontecimentos anotados servirem ao autor para refletir sobre si, para esclarecer um aspecto de seu ser: “[s]ua curiosidade não é do exterior, mas do próprio interior. Ele é o verdadeiro sujeito do qual trata sua escrita, a matéria de suas notas tomadas no dia-a-dia" (GIRARD, op. cit., p. 16, tradução nossa) ${ }^{11}$. Para Didier (op. cit., p. 08), o aspecto íntimo do diário não é mais do que a presença do eu, de um olhar que é exclusivamente aquele do diarista. A problemática que se coloca é como saber se o diarista é sincero ou não? Muitas vezes, ele fará de si mais um autorretrato do que uma fotografia, já que os tabus pesam aí como em outros espaços. O diarista pode relatar estrategicamente suas hesitações ao invés de expor conclusões definitivas. A instabilidade e contradição dessa representação do eu mantém, no fim das contas, a instabilidade e a contradição da representação do desejo no diário; submetido à autocensura,

\footnotetext{
${ }^{11}$ Texto original: «Sa curiosité n'est pas du dehors, mais de l'intérieur de lui-même. Il est luimême le véritable sujet dont traite son écrit, il est lui-même la matière de ses notes écrites au jour le jour » (GIRARD, op.cit., p. 16).
} 
porém, sempre presente. Observado por essa perspectiva, talvez valha mais encarar a matéria do diário como uma série de pegadas datadas, rastos reveladores de um eu.

Perdurar-se por longo período de tempo é também uma característica do diário íntimo. Todavia, o ritmo e a frequência podem variar mesmo em se tratando de diários de um único autor. O essencial é que as inscrições datadas criem um tipo de encadeamento no tempo.

Outro aspecto relevante é o diário não se destinar ao público, antes conserva caráter reservado, visto que o autor não escreve primordialmente visando a ter leitores. Esse caráter privado é comprovado também pelo fato de os diários, ao menos até o início do século $X X$, não serem entregues à publicação pelo próprio autor. É digno de nota repetir que até esse momento as publicações foram sempre póstumas. Diferente postura assume o memorialista que, em geral, ao menos até o século XIX, publica suas memórias relatando, de modo mais impessoal, os eventos dos quais participou ativamente a partir da perspectiva de um eu glorioso ligado à dimensão histórica. O tom das memórias é elevado, visto cumprir o objetivo de engrandecer a figura de quem se fala, celebrando o sucesso da trajetória percorrida por meio da demonstração de onde o sujeito partiu e aonde chegou.

Segundo acepção corrente no século XVII, memórias são o produto da escritura individual de personalidades públicas sobre a repercussão de seus atos, o brilho da própria glória, ou sobre homens ou fatos dos quais foram testemunhas privilegiadas; destinam-se a ser lidas (CHARTIER, op. cit., p. 332).

Texto pretensamente autônomo, o diário íntimo, entretanto, não deixa de questionar seu destino e de seu leitor. Do interior de uma escrita, dita pessoal, 
muitos são os diaristas que postulam o outro, decorre daí a presença da segunda pessoa. Se por um lado alguns diaristas chegam a permitir a leitura de suas notas por pessoas mais próximas, por outro lado a intrusão de um olhar indesejado nas páginas manuscritas pode ter repercussão devastadora sobre a escrita íntima, como bloqueio da escrita ou destruição das folhas lidas.

Observe-se, nesse sentido, que o diário é o espaço onde o autor dirigese a si próprio, colocando sua personalidade como o próprio objeto de seu olhar. Em uma palavra: sentimento e sensação dominam a atmosfera do diário. Maciel (2002, p. 02) resume bem aquilo que vem a ser um diário: "[trata-se de] uma crônica cotidiana de uma experiência pessoal e quem o escreve (e se inscreve) interessa-se por anotar pequenas coisas do dia-a-dia ao lado das grandes dúvidas e indagações humanas". De forma mais abrangente, Coutinho (2001, p. 593) o define como "gênero literário usado por escritores ou pessoas cultas para registrar pensamentos, acontecimentos de suas vidas ou de outrem, comentários sobre leituras feitas".

Escrever um diário íntimo é uma ação solitária; assim, exprime o estado de alguém que está ou se sente só. Contudo, o ato da escrita Ihe permite, de algum modo, escapar dessa solidão à medida que obriga o sujeito a se colocar em face de si mesmo, a se desdobrar num eu-sujeito que observa e um euobjeto que projeta fora de si. Resumiu Dider (op. cit., p. 116, tradução nossa): "[o] diarista é dois: aquele que age e se observa agir e que escreve" ${ }^{12}$. Desse modo, o diarista será continuamente ao mesmo tempo sujeito e objeto de seu discurso. À vista disso, podemos pensar que o diarista, enquanto escritor e

\footnotetext{
${ }^{12}$ Texto original: «Le diariste est deux: II est celui qui agit et celui qui se regarde agir, et qui écrit » (Dider, op.cit., p. 116).
} 
também matéria de sua escrita, encarna dois personagens. Surge daí o caráter duvidoso no que diz respeito à sinceridade do narrador do diário. Ambos encontram nas palavras que reúnem um refúgio não só contra a solidão, um remédio à aflição, mas também contra o julgamento do mundo. Nesse cenário, a escrita diária aparece como uma regularidade salvadora, expurgatória.

Encontramos nas páginas do diário íntimo o sentimento de um irremediável fracasso que, portanto, revela a fraqueza do eu. Esse sentimento ressoa em função de um longo apelo à glória presente nas entrelinhas do diário.

Esse sentimento [de fracasso] colore todas as páginas dos diários íntimos e explica sua atmosfera dominante. Insatisfação e miséria que dele resultam, retornos graves sobre si, entrecortados de movimentos de orgulho, ruína das esperanças, inanição da existência, vaidade do esforço, oferecem tantas expressões de uma mesma experiência repetida que tem em si origem comum. Mas, não há fracasso absoluto. $O$ fracasso apenas pode ser sentido em virtude de um objetivo prévio que não foi atingido. É essencialmente relativo e mede-se pela distância que separa o objetivo fixado da real linha de chegada (GIRARD, op. cit., p. 510, tradução nossa) $)^{13}$.

Ecoa um mal-estar mais ou menos profundo do indivíduo em face de si mesmo, dos outros e da existência. Muitas vezes, o diário nasce da tomada de consciência desse mal-estar, da contradição na qual o sujeito encontra-se enredado. As motivações que levam à escrita do diário sobrevêm, frequentemente, quando a identidade do sujeito se vê colocada em perigo ou,

\footnotetext{
${ }^{13}$ Texto original: «Ce sentiment [d'échec] colore toutes les pages des journaux intimes et explique leur atmosphère dominante. Insatisfaction, et misère qui en résulte, retours sévères sur soi, entrecoupés de mouvements d'orgueil, ruine des espérances, inanité de l'existence, vanité de l'effort, offrent autant d'expressions d'une même expérience répétée, et ont en lui leur racine commune. Mais il n'y a pas d'échec absolu. L'échec ne peut être ressenti qu'en fonction d'un objectif préalable, qui n'a pas été atteint. II est essentiellement relatif, et se mesure par la distance qui sépare du but fixé et de la ligne réelle d'arivée » (GIRARD, op.cit., p. 510).
} 
ao menos, encontra-se numa situação de vulnerabilidade. A escrita diarista relaciona-se ainda às experiências físicas de sofrimento (da velhice e do declínio de si, doenças), de transformação (transtornos da adolescência, gravidez), às situações de prisão, crises afetivas (amor, luto, separação, dor da solidão), espirituais e intelectuais ou aos períodos de profundas reviravoltas e violências históricas, crises coletivas que ressoam no plano individual (diários de guerra).

O conflito essencial presente nas páginas do diário diz respeito ao conflito íntimo entre as forças que mantêm o sujeito no plano subjetivo, ou seja, dentro de si, e as forças que o arrastam para fora, entre o subjetivo e o objetivo. Nesse sentido, podemos ver o diário como manifestação momentânea desse esforço contínuo de adaptação e de compreensão num movimento constante de fora para dentro, sendo fora - os outros, a vida ativa e social, o ofício, os eventos históricos; e dentro - a interioridade que o diário permite descobrir. Nesse movimento, o retorno ao interior pode ser assimilado a um segundo nascimento concretizado por meio da palavra, que traz à luz o discurso interior corporificando esse eu.

A trama banal, da vida cotidiana, configura-se como o lugar onde o diarista concebe como pertencente a si próprio - emoções amorosas, inquietude filosófica, presença da família, circunstâncias de aparência fortuita, mas que tem papel revelador para esse eu. No plano sentimental, o diário acalma a indecisão; no racional, substitui, pela reflexão, o devaneio indeciso. Quando escreve, o diarista consegue transpor alguma coisa de dentro para fora, acabando por dar contorno aos sentimentos. Nesse ponto, faz-se interessante destacar o papel curativo do diário, cujas anotações podem ser 
equivalentes à fala do paciente no divã. Sem a pretensão de nos aprofundar nessa abordagem, interessa-nos apenas apontar a função psicanalítica da escrita diarista que, enquanto liberadora de fantasmas, pode promover equilíbrio.

Para muitos artistas, o diário constitui um modo de expressão paralela, um espaço que dá conta de sua experiência, de seus projetos, onde tenta formular uma teoria da arte. Para outros, o diário constitui uma sorte de exercício moral. Vemos aqui até que ponto ele é tributário, pelas origens e funcionamento, do exame de consciência e de toda uma técnica espiritual desenvolvida sistematicamente pelo cristianismo.

O diário pode ser também um reservatório de idéias, de projetos, de temas que serão utilizados em outro momento. Esse aspecto é, geralmente, observado no caso de diários de escritores, onde as reflexões expressas relacionam-se com as obras, sendo o diário, assim, uma espécie de banco de ensaio, de observatório, de ateliê.

O principal papel do diário é fazer um balanço, que pode ser negativo ou positivo, de ordem financeira, profissional, pessoal (sinais de envelhecimento, por exemplo). O diário registra as perdas - no âmbito físico e no moral. O diarista pode lamentar o desperdício do tempo e das forças, é onde se acertam as contas.

O diário pode ser ainda visto como uma forma de poupar fatos, pensamentos, nada deve ser desperdiçado. Essa idéia ligada à visão burguesa, expressa o desejo de conservação. O objetivo é ancorar o tempo por meio da escrita cotidiana, registrar o presente numa sequência instantânea que preserva o frisson da experiência vivida por meio do registro dos grandes ou 
pequenos acontecimentos. Evocamos aqui a imagem de garde-mémoire delineada por Simonet-Tenant (op. cit., p. 115) ao tratar das funções do diário. Aliás, percebe-se nos diaristas a preocupação de tudo conservar, de anotar tudo que lembra, a fim de que nada se perca, uma vez que "o escrito tem mais peso do que o vivido" (DIDIER, op. cit., p. 54, tradução nossa) ${ }^{14}$.

Rupturas, digressões e retornos marcam a narrativa do diário, pontuado pelos acontecimentos cotidianos registrados, muitas vezes, com frases nominais, de forma rápida e resumida, sendo que o diarista pode, em seguida, comentá-los mais profundamente. Formalmente, as rupturas aparecem na frase sinalizadas por travessões, parênteses, reticências. $O$ uso da inicial do nome da pessoa ou alguma letra para representar de quem se fala, em geral, em maiúsculo, uso do discurso indireto, diálogos reportados - indicam a presença do outro. Tal presença frequentemente é mantida em secreto, dado o destino póstumo das páginas manuscritas ser inteiramente incerto. Nesse sentido, a fim de evitar a descoberta involuntária de sua intimidade, o diarista serve-se de diversos subterfúgios: emprego de uma linguagem codificada, uso da terceira pessoa. Outra estratégia linguística observada é o uso de palavras estrangeiras, recurso ligado ao caráter descontínuo do gênero, em alguma medida, impõe uma ruptura da narrativa ao leitor, caso este não domine o idioma utilizado.

Ilustram a escrita diarista, as palavras de Simonet-Tenant:

A escrita diarista, modesta e paradoxal é para alguns, para muitos, o indispensável duplo de papel da vida, o avesso repleto de costuras e de retomadas da existência, a restituição mental que duplica o batimento do coração a cada instante até

14 Texto original: « l'écrit a plus de poids que le vécu » (DIDIER, op.cit., p. 54). 
que ele pare sem avisar (SIMONET-TENANT, op. cit., p. 182, tradução nossa) ${ }^{15}$.

\subsection{Diário Íntimo e Autobiografia}

Dado haver semelhanças entre a autobiografia e o diário íntimo, visto filiarem-se a um vasto conjunto das escritas do $e u$, cabe aqui breve reflexão acerca das particularidades que distinguem cada um desses gêneros, considerados por Gusdorf (1991, p. 275, tradução nossa) "duas entidades autônomas" ["deux entités autonomes"].

O cotejo entre esses dois gêneros evidencia de pronto a fragmentação da escrita como um aspecto revelador que distancia formalmente autobiógrafos e diaristas à medida que estes são livres para iniciar cada nota registrando as impressões fugitivas do modo como lhe vem à mente, ao passo que aqueles têm em mente um projeto de totalidade.

$\mathrm{Na}$ autobiografia, o leitor acompanha a trajetória daquele que a escreve do início, em geral, o nascimento, a um momento final, que pode ser o fim de alguma etapa da vida - infância, juventude, maturidade ou simplesmente o fim da redação. Ou seja, a autobiografia tem caráter acabado, deve apresentar começo, meio e fim, trata-se de uma obra. O diário, por sua vez, trata-se de uma simples coletânea de inscrições, acaba sendo uma obra por acumulação. Por essa razão, tem início e fim incertos, podendo ser interrompido por um tempo mais ou menos longo sem que o leitor seja avisado, já que, em tese, o diarista não tem um público em vista. Por isso mesmo, expõe o estado bruto do

\footnotetext{
${ }^{15}$ Texto original: «L'escriture journalière, modeste et paradoxale, est pour d'aucuns, pour beaucoup, l'indispensable double de papier de la vie, l'envers plein de coutures et de reprises de leur existence, la restitution mentale qui double le battement d'un coeur, à chaque instant, et jusqu'à ce qu'il s'arrête sans prévenir » (SIMONET-TENANT, op.cit., p. 182).
} 
eu. Diferentemente, o autobiógrafo remodela a imagem de si a partir de suas lembranças, propõe "a imagem de uma personalidade harmoniosa, posando para figurar aos olhos dos outros e aos próprios olhos" (GUSDORF, op. cit., p. 327, tradução nossa) ${ }^{16}$.

Sendo assim, a narrativa autobiográfica é cuidadosamente preparada, implica maior recuo temporal das circunstâncias imediatas; estas figuram largamente no diário, cuja escrita não demanda elaboração acurada.

As notas que aí se lançam não demandam preparação breve ou mais longa, exprimem circunstâncias do pensamento ou do sentimento de acordo com as vicissitudes da atualidade cotidiana (Ibid., p. 318, tradução nossa) ${ }^{17}$.

Gostaríamos ainda de sublinhar o caráter espontâneo da escrita diarista, observado já no suporte - agendas, cadernos, folhas soltas - que pode ser carregado pelo escritor a fim de que este tome suas notas não importa onde esteja. O autobiógrafo acaba, geralmente, restringindo-se ao seu escritório, ou espaço que o valha, para confeccionar sua biografia, definida por Lejeune (2008, p. 14) como sendo uma "narrativa retrospectiva em prosa que uma pessoa real faz de sua própria existência, quando focaliza sua história individual, em particular a história de sua personalidade".

Tomando por base os elementos que compõem a autobiografia, segundo esquema analítico proposto por Lejeune (Id., p.14), o diário se distingue dessa por apresentar um elemento diferente na categoria "posição do

\footnotetext{
${ }^{16}$ Texto original: «l'image d'une personnalité harmonieuse, prenant la pose pour faire figure aux yeux d'autri et à ses propres yeux » (GUSDORF, op.cit., p. 327).

${ }^{17}$ Texto original: «Les notes que l'on y jette ne demandent pas de préparation, brèves ou plus longues, elles expriment des ocurrences de la pensée ou du sentiment selon les vicissitudes de l'actualité quotidienne » (lbid., p. 318).
} 
narrador". Não obstante nos diários e autobiografias a posição do narrador assemelhe-se quanto à "identidade do narrador e do personagem principal" (Ibid., p. 14), distingue-se pela "perspectiva retrospectiva da narrativa" (Ibid., p. 14), uma vez que esse traço é observado apenas nas autobiografias, posto que nos diários os registros se colem muito mais ao presente do fato narrado ancorado na dimensão imediata do cotidiano.

Da mesma forma que vigília e sonho, ficção e realidade se complementam, mas raras vezes identificam-se, a linha que afasta a autobiografia do diário configura-se igualmente tangente, visto a matéria essencial de um e outro ser a mesma: a biografia, sempre, em alguma medida, recriada.

Toda biografia é trabalho de interpretação e, portanto, de imaginação criadora. Por isso nenhuma biografia é definitiva, e sempre será possível refazê-la, a partir de dados basicamente iguais, pois todo biógrafo faz viver o biografado, mais ou menos como o ficcionista faz viver as personagens de sua imaginação. No caso da autobiografia, o processo não parece muito diverso, apesar da ilusão de maior verdade: ninguém diz tudo a respeito de si mesmo, e a verossimilhança e o sentido de uma vida dependem de critérios que não são dados, diretamente, pela ação (LEITE, 1979, p. 25).

Tendo em vista os aspectos formais e constitutivos do diário íntimo, passaremos agora a observar o Diário Íntimo de Lima Barreto atentando para a caracterização aqui descrita desse tipo de diário enquanto gênero literário, com o intuito de avaliar em que medida esse autor respeitou as regras do gênero ao qual sua obra filia-se pelo título. 


\subsection{O Diário Íntimo por Francisco de Assis Barbosa}

Passados três anos da morte de Lima Barreto, pensou-se em publicar suas notas íntimas. O primeiro a cogitar essa idéia foi A. J. Pereira da Silva ${ }^{18}$ que por escrúpulo, em virtude das notas de Lima soarem, a seu ver, em muitos momentos como inconvenientes, logo abandonou essa idéia. As páginas íntimas, compostas materialmente por folhas soltas e cadernetas permaneceram, num primeiro momento, com a família do autor. Atualmente, acham-se na Biblioteca Nacional do Rio de Janeiro, onde se encontram reunidos todos os manuscritos de Lima Barreto - cadernos, cadernetas, tiras soltas, folhas pautadas ou sem linha - em poder da Seção de Manuscritos dessa biblioteca, compondo a "Coleção Lima Barreto".

Grande parte do material que forma o chamado diário está disponível apenas em microfilmes precariamente catalogados, visto as notas íntimas terem sido postas junto com outros papéis de natureza diversa. A maioria das notas presentes no diário podem ser visualizadas no documento 13 de nome “Notas de um Diário 1904 - 1914 [19_]", contido no microfilme de localização I - 06. 29; I -06. 033. Trata-se de 93 tiras de papel, o que contabiliza 162 páginas, conforme descrição verificada no microfilme. As demais notas que dão corpo ao diário foram escolhidas em meio aos papéis vários de Lima Barreto, provavelmente obedecendo ao critério da temática de fórum íntimo.

Foi desse modo que, em 1953, Francisco de Assis Barbosa, com a colaboração de Antônio Houaiss e Cavalcanti Proença, concretizou o projeto de

\footnotetext{
${ }^{18}$ Antônio Joaquim Pereira da Silva (1876-1944), natural da Paraíba, foi poeta, atuou também como jornalista na imprensa carioca. Em 1933, foi eleito para ocupar a cadeira número 18 da Academia Brasileira de Letras.
} 
publicação do diário, reeditado três anos mais tarde pelo mesmo pesquisador com acréscimos e modificações. Assim, o diário de Lima ganhou corpo através do trabalho cuidadoso de Barbosa em compilar suas anotações registradas em cadernetas e em folhas avulsas, algumas a lápis, conforme indicam as notas explicativas ao fim de cada capítulo ${ }^{19}$ do Diário Íntimo. Deveu-se a Barbosa, portanto, a constituição material dessa obra. Cabe aqui salientar que, embora Lima não tivesse mantido um caderno específico, cuja finalidade fosse ser um diário, percebe-se pelo teor intimista e formato datado das anotações desse material encontrado, tratar-se de páginas diarísticas. Daí decorreu, a nosso ver, a opção do organizador em acrescentar o adjetivo íntimo ao título desse diário. Reforçou essa opção, o eu enunciado colocar-se em primeiro plano de modo introspectivo, expondo suas insuficiências e fraquezas. É imprescindível notarmos haver da parte de Lima a intenção de escrever um diário, conforme evidencia de pronto o título à entrada de 1903 "Um Diário Extravagante" (DI, p. 33 - Sem data, 1903) ${ }^{20}$, enunciando dessa forma seu projeto. Logo, tinha o intuito de construir um diário do tipo "extravagante" e não íntimo; fundando, assim, um subgênero original no âmbito do gênero diário que teria sido desse modo legitimado se aos escritos limabarretianos tivessem concedido maior atenção.

No que concernem aos acréscimos à segunda edição do diário, de acordo com nota prévia de Barbosa, juntou-se "às anotações da vida íntima e notas de leitura, os esquemas de romances frustrados, primeiras tentativas do ficcionista, ainda em plena juventude, seguidos às vezes de capítulos inteiros,

\footnotetext{
${ }^{19}$ Consideraremos aqui cada ano do diário de Lima Barreto como um capítulo.

${ }^{20}$ Todos os excertos citados do Diário Íntimo de Lima Barreto serão identificados pela sigla $D I$ e pertencem à segunda edição dessa obra (1956). Incluiremos também a data referente ao excerto para situar melhor o leitor.
} 
talvez completos, ao lado de outros apenas esboçados" (BARRETO, 1956a, p. 20). Eis aí a matéria constitutiva do diário limabarretiano que será analisada do ponto de vista formal, ou seja, apoiados na segunda edição preparada por Barbosa, investigaremos como se construiu esse diário atentando para os aspectos que o caracterizam como íntimo, dado o título escolhido pelo organizador, e os traços que o qualifica como "extravagante", de acordo com a denominação proposta por Lima Barreto.

\subsection{De Extravagante a Íntimo: o Diário de Lima Barreto}

As anotações que compõem as páginas da segunda edição do diário de Lima estendem-se de 1900 a 1921 . Visto tal número de anos, o leitor imaginará que esse diário é relativamente longo, dado se nesse intervalo de vinte e dois anos Lima houvesse tomado nota diariamente. Contudo, logo que passamos a folheá-lo percebemos a falta de regularidade das anotações. Esse aspecto pode ser verificado pela ausência de notas ao longo dos anos de 1901, $1902 \mathrm{e}$

1909. Vale destacar que em nenhuma das edições foi verificado qualquer tipo de registro nesses anos, ou seja, reduz-se então para dezenove anos o período anotado nesse diário.

Em relação ainda à regularidade da escrita, há outro aspecto a sublinhar: ao longo desse período de escritura em nenhum dos anos constam anotações diárias. Ao contrário, as notas são bem esparsas, o que quer dizer que há registros de alguns dias de determinados meses. $\mathrm{O}$ talhe das anotações é também bem variável, enquanto há notas desenvolvidas ao longo de duas páginas, outras não passam de uma ou duas linhas, traço comum nos diários, 
já que o ritmo da escrita depende da vontade e da disponibilidade do diarista. Do mesmo modo, há dias em que Lima tomou várias notas a respeito dos mais variados assuntos, em outros, escreveu apenas uma nota.

O ano de 1905 é o de registros mais abundantes. Somente no mês de janeiro verificamos vinte notas, além de outras não sequenciais ao longo dos meses de fevereiro, junho, julho e outubro. As entradas das anotações é outro traço relevante, são assinaladas ora por data mais a indicação do mês, ora por somente data ou por somente mês e há ainda entradas não datadas, essas, a nosso ver, figuram no diário mais pela escolha de Barbosa do que pelo caráter que define entradas diarísticas - datação. Se por um lado o fato de muitas das entradas serem datadas, marca formalmente o intuito de escrever um diário, traço indispensável para esse gênero, por outro as notas sem data assinalam a intervenção do organizador.

É interessante observar que Lima percebeu a falta de sequência na escritura do diário, chegando a comentar:

\footnotetext{
Há mais de dez dias que não tomo notas. Nada de notável me há impressionado, de forma que me obrigue a registrar. Mesmo nos jornais nada tenho lido que me provoque assinalar, mas como entretanto eu queria ter um registro de pequenas, grandes, mínimas idéias, vou continuá-lo diariamente (DI, p. 99 - 20 de fevereiro de 1905).
}

Esse excerto demonstra que Lima atentava para esta característica do diário - a periodicidade, aspecto fundamental na confecção desse gênero que ele procurava respeitar. Seguindo Dider (op. cit., p. 09), Lima poderia ser considerado o tipo de diarista negligente [nonchalant] "que fica em atraso, visto isso, esforça-se para tapar quinze dias, um mês de silêncio e em branco no 
diário" (tradução nossa) ${ }^{21}$, posto não manter suas notas em dia.

O uso dos advérbios de tempo - hoje e ontem, pontua o registro de muitas das entradas respectivamente no dia relativo aos fatos narrados e no dia anterior. Outro marcador de regularidade da escrita é, como no trecho supracitado, a indicação da quantidade de dias nos quais Lima nada anotou: "Desde domingo que não tomo notas. Hoje, 17, vou recapitular estes três dias" (DI, p. 86 - 17 de janeiro de 1905). Nota-se aqui se tratar de uma terça-feira, pois na sequência, ele passou a relatar os acontecimentos de domingo, depois de segunda, em seguida, usou o advérbio hoje para marcar os fatos de terçafeira. Passados alguns dias, em 24 de janeiro desse mesmo ano, registrou novamente: "Desde sábado, ou antes, desde sexta-feira (20), que não tomo notas" (DI, p. 89).

A linguagem usada no Diário é bem coloquial, permeada por adjetivos e advérbios que intensificam as descrições feitas, revelando os efeitos de cada situação em Lima Barreto. Chama a atenção, o uso contínuo de palavras em francês, tais como - chance, toilette, flirt, gauche, touristes, rendez-vous, dentre outras. Sinais de reticência, pontos de exclamação e travessões, abundam nas páginas desse diário, marcando o caráter subjetivo próprio do diário íntimo.

Conforme podemos observar, conquanto Lima se esforçasse para manter seu diário em dia, a periodicidade de sua escritura configura-se de forma bastante diversa. Talvez esse fato sinalize para o tipo de vida levado pelo autor que teve uma existência conturbada, marcada especialmente pela

\footnotetext{
${ }^{21}$ Texto original: « qui prennent du retard et, après coup, s'efforcent de combler quinze jours, un mois de silence et de blanc dans leur journal » (DIDIER, op. cit., p. 09).
} 
doença do pai e pela falta de recursos financeiros da família ${ }^{22}$. Acreditamos ser possível atribuir aos diversos problemas pessoais do autor essa falta de regularidade das anotações, além de não descartamos a possibilidade de sumiço de páginas íntimas. Vale ressaltar as duas internações no Hospício Nacional de Alienados por causa do alcoolismo - de agosto a outubro de 1914 e, mais tarde, do dia de natal de 1919 a fevereiro do ano seguinte.

Nessa segunda internação escreveu o Diário do Hospício, cujas primeiras anotações dataram de 04 de janeiro de 1920, ou seja, passados dez dias de internação, e estenderam-se até o dia 28 do mesmo mês. Os manuscritos compuseram-se de 79 tiras de papel, registrados a lápis ou a caneta, aproveitadas na frente e no verso, encontram-se igualmente na Seção de Manuscritos da Biblioteca Nacional. Os registros, divididos em nove capítulos temáticos, descreveram os aspectos físicos das seções do hospício, os tipos de loucos, os guardas, enfermeiros e médicos que aí trabalhavam, além de trazer o olhar de Lima sobre a loucura de um modo geral e seu testemunho pessoal das causas que o arrastavam para ali.

Muitas causas influíram para que viesse a beber; mas, de todas elas, foi um sentimento ou pressentimento, um medo, sem razão nem explicação, de uma catástrofe doméstica sempre presente. Adivinhava a morte de meu pai e eu sem dinheiro para enterrá-lo; previa moléstias com tratamento caro e eu sem recursos; amedrontava-me com uma demissão e eu sem fortes conhecimentos que me arranjassem colocação condigna com a minha instrução; e eu me aborrecia e procurava distrair-me, ficar na cidade, avançar pela noite adentro; e assim conheci o chopp, o whisky, as noitadas, amanhecendo na casa deste ou daquele (BARRETO, 2010a, p. 60-61).

\footnotetext{
${ }^{22}$ Em 1902, João Henriques, pai de Lima Barreto, começou a padecer de distúrbios mentais. Em razão da doença do pai, Lima passou à chefia da casa, o que o forçou a abandonar os estudos na Politécnica.
} 
Acompanhamos uma análise pessoal de um interno do hospício sobre a loucura alheia e sobre sua própria pretensa insanidade, porquanto os prontuários do hospício mostraram-no absolutamente lúcido ${ }^{23}$. Há ainda nesse diário notas fragmentadas, semelhantes a tópicos indicativos da matéria que deveria desenvolver reflexão, e impressões da vida no manicômio que, posteriormente, originaram o romance inacabado O Cemitério dos vivos, publicado no mesmo ano da primeira edição do Diário Íntimo (1953). Ainda que não seja nossa intenção analisar o Diário do Hospício, tão pouco nos deter nas relações de contiguidade entre esse diário e o romance mencionado, vale sinalizar o emaranhado entre ficção e realidade que percorre ambos os textos limabarretianos. Com efeito, o breve cotejo entre esses textos evidencia rapidamente fatos da vida real transcritos no diário presentes na narrativa do romance e o contrário também se observa, matéria ficcional, personagens e cenas, figurando nesse diário ${ }^{24}$.

Cabe frisar que, assim como Barbosa (BARRETO, 1956c, p. 25), tomamos o Diário do Hospício como um prolongamento do Diário Íntimo, dado a coincidência temporal das notas que compõem um e outro. Essa postura, portanto, nos aproxima da consideração de Barbosa, que, aliás, agrupou ambos os diários em único volume na edição de 1953, sendo posteriormente separados na reedição de 1956, e nos distancia da posição sustentada por Resende (1993, p. 172) que classificou o Diário do Hospício como um "corpus

${ }^{23}$ Cf. cópia das observações clínicas do paciente Afonso Henriques de Lima Barreto, disponível em Barbosa (2003, p. 365-374).

${ }_{24}$ Provavelmente pelas interpolações entre as narrativas do Diário do Hospício e O Cemitério dos Vivos Eliane Vasconcellos, ao organizar a obra completa de Lima Barreto (2001), nomeou de "Anotações para O Cemitério dos Vivos" a narrativa correspondente ao Diário do Hospício, assim considerado por Barbosa (1953; 1956). A organizadora desconsiderou, portanto, 0 caráter diarístico das notas tomadas no hospício. 
à parte". Reconhecemos, porém, que esses diários guardam especificidades: 0 Íntimo marcado especialmente por fatos cotidianos corriqueiros e impressões de leituras, enquanto que o do Hospício focalizou os acontecimentos e sentimentos próprios desse espaço. São da mesma natureza, visto filiarem-se pela forma (datação) e conteúdo (fatos da vida pessoal) ao gênero diário.

Para nós, os diários limabarretianos ligam-se pelo fio da louca lucidez da vida - entrevista no Diário Íntimo - e a louca lucidez da loucura - apreendida do Diário do Hospício, de um escritor que fora e dentro do manicômio passou por experiências de sujeição e opressão, daí a necessidade de se servir de páginas íntimas para expressar-se longe da censura alheia, buscando adaptarse e compreender, num movimento que vai do espaço público para o divã da página branca, os outros, a vida ativa e social, posto ter sido mantido afastado da sociabilidade literária, ou seja, dos círculos canônicos, a exemplo da Academia Brasileira de Letras. Incompreendido em sua conduta, resultado de profundo entendimento de uma organização social elitista, foi subtraído da sociedade quando enviado ao hospício ora pela polícia, ora pela família.

É preciso reconhecer ainda que os diários serviram de ateliê para esse escritor, espaço reservatório de ideias, de maneira declarada, caso do Diário do Hospício; lembramos aqui da entrevista concedida, quando de sua segunda estada no Hospício Nacional de Alienados, ao jornal $A$ Folha, ocasião em que Lima declarou:

Tenho coligido observações interessantíssimas para escrever um livro sobre a vida interna dos hospitais de loucos. Leia $O$ Cemitério dos vivos. Nessas páginas contarei, com fartura de pormenores, as cenas mais jocosas e as mais dolorosas que se passam dentro dessas paredes inexpugnáveis. Tenho visto 
coisas interessantíssimas (BARRETO, 1956c, p. 258) ${ }^{25}$.

No caso do Diário Íntimo o reaproveitamento das notas configura-se menos evidente, demandando exame mais apurado para enxergar essas interpolações. A leitura atenta da ficção limabarretiana deixa entrever situações presentes nos diários que the serviram de mote para a composição de romances e contos, havendo mesmo trechos dos diários recuperados quase que literalmente na produção ficcional. Sem pretendermos esgotar essa investigação, vejamos um exemplo:

Mas, hoje! Hoje! Já posso alguma coisa e amanhã poderei
mais e mais. Não pararei nunca, não me deterei; nem a
miséria, as perseguições, as descomposturas me deterão.
Sacudi para longe o fantasma do medo; sou forte, penso, tenho
coragem... Nada! Nada! Nada! É que senti que a ciência não é
assim um cochicho de Deus aos homens da Europa sobre a
$\frac{\text { misteriosa organização do mundo }}{1905, \text { grifos nossos). }}$

Esqueci-me um momento dos meus propósitos de alto debate metafísico, de ferir a Ciência nas suas bases e contestar-lhe esse caráter de confidência dos Deuses, que os pedantes querem dar-lhe, para justificarem a vaidade de que transandam, por saber dela um poucochito, levando, com as suas asserções arrogantes, tristeza no coração dos outros e discórdia entre os homens (BARRETO, 2010a, p. 164, grifos nossos).

Como se vê, o primeiro excerto, que compõe o Diário Íntimo, foi recuperado na narrativa de 0 Cemitério dos vivos de forma quase integral, pondo em evidência reflexões que perseguiam o autor, dado a distância temporal de um e outro registro. Ora, esse procedimento leva-nos a apontar relações de contiguidade não apenas entre esse romance e o Diário do Hospício, conforme anunciado por Lima, mas também com o Diário Íntimo, de

\footnotetext{
${ }^{25}$ Entrevista publicada na edição de 31 de janeiro de 1920 de $A$ Folha, do Rio de Janeiro.
} 
modo que a semelhança entre as passagens citadas deixa entrever, marcando, uma vez mais, as interfaces entre os diários.

Pontuadas as ligações entre os escritos diarísticos, é hora de volver nosso olhar tão somente para o Diário Íntimo, corpus aqui privilegiado para análise. O primeiro capítulo desse diário de Lima (1900) trata-se de uma de suas primeiras tentativas de romance, datada de dois de julho. Ambientada nos ares da Escola Politécnica delineia um personagem negro chamado Tito Brandão, considerado por uns inteligente e honesto e por outros muito orgulhoso. Tal narrativa é retomada no diário quatro anos mais tarde em notas sem data (DI, p. 54-56/65), contudo esse projeto não foi à frente. Barbosa justificou em nota de rodapé a inclusão desses embriões de obras ficcionais de Lima, por considerar que "neles se encontra muita coisa digna de interesse, não só do ponto de vista biográfico, mas também do literário" (BARRETO, 1956a, p. 32).

Consideramos, porém, que o diário de Lima iniciou-se de fato em 1903, com entrada intitulada "Um Diário Extravagante", seguida de apresentação pessoal do autor e de seu audacioso projeto literário.

Eu sou Afonso Henriques de Lima Barreto. Tenho vinte e dois anos. Sou filho legítimo de João Henriques de Lima Barreto. Fui aluno da Escola Politécnica. No futuro, escreverei a História da Escravidão Negra no Brasil e sua influência na nossa nacionalidade (DI, p. $33-1903)$.

Cumpre-se aqui ressaltar novamente o tipo de diário proposto por Lima - extravagante - indicando aquilo que escapa às normas do bom senso, por isso as notas ali contidas podem atestar o caráter excêntrico dessa personalidade. Ao adjetivo extravagante liga-se, por contiguidade, o verbo 
extravasar, nesse sentido, esse diário pode ser encarado como o espaço onde o eu confessional derrama-se pela página, livre das bordas, poderia assim extravagar nesse terreno, distante de um padrão social, psicológico e literário. Tudo leva a crer que contribuíram para o início do diário, em 1903, as circunstâncias que o antecederam: no ano anterior o pai de Lima enlouquecera forçando-o a abandonar a Politécnica, em virtude da necessidade de obter recursos para o sustento da família.

Como filho mais velho, cabe a Afonso assumir a chefia da casa, arcando com a responsabilidade de cuidar do pai demente, de alimentar e vestir mais oito pessoas: seus três irmãos, Prisciliana, os três filhos desta, além do preto velho Manuel de Oliveira, agregado dos Limas Barretos (BARBOSA, 2003, p. 130).

Essa situação de mudança no curso da vida, certamente corroborou para a escrita intimista. É possível perceber que Lima tomava suas notas em casa, retirado em seu quarto - espaço de recolhimento e de intimidade: "[...] Ontem, eram onze horas, eu estava no meu quarto, escrevendo [...]" (DI, p. 75 - 03 de janeiro de 1905). Desenrola-se nesse momento o rolo no qual se encontram inscritos os fatos, do dia decorrido, guardados no livro imaginário da memória.

Ainda segundo Barbosa (op. cit., p. 134), Lima sentiu o desejo de recorrer ao álcool logo depois do pai apresentar os primeiros distúrbios mentais, provavelmente, forma encontrada para amenizar a gravidade do problema familiar que teria de enfrentar, resultado da "tristonha moléstia" de João Henriques. Esse vício pode ser também observado como forma de inserção social, cumpriria o papel de mantê-lo em contato com o mundo intelectual por meio da boêmia, uma vez distante da faculdade. 
Sendo Lima literato, não é de se estranhar o destaque dado, logo no início do diário, ao projeto de escrever o que seria sua obra-prima, fato que marca a importância de tal projeto para o autor, cujo diário foi um espaço fecundo de permanente gênese literária. Com efeito, seu diário é repleto de apontamentos para a confecção de obras ficcionais, arcabouço de ideias a serem aproveitadas. Figuram ainda no diário desse escritor, que foi profícuo leitor, inúmeras citações de obras de autores brasileiros e estrangeiros, sobretudo, referências a autores e obras francesas, objeto de análise no segundo capítulo dessa dissertação. Dentre os projetos literários, destacam-se os esboços $(D I$, p. $57-60$ - 1904) para a primeira versão inacabada de Clara dos Anjos; o planejamento ( $D I$, p. 115-121 - 1906) dos capítulos da obra Vida e Morte de M. J. Gonzaga de Sá que Lima começara a trabalhar em 1906, mas que viria a ser publicada somente em 1919; notas de 1910 para o livro Triste fim de Policarpo Quaresma, escrito subitamente de janeiro a março do ano seguinte, apareceu em volume em 1916, cuja publicação foi objeto de comentário do autor:

O Policarpo Quaresma foi escrito em dois meses e pouco, depois publicado em folhetins no Jornal do Comercio da tarde, em 1911. Quem o publicou foi o José Félix Pacheco. Emendeio como pude e nunca encontrei quem o quisesse editar em livro. Em fins de 1915, devido a circunstâncias e motivos obscuros, cismei em publicá-lo. Tomei dinheiro daqui e dali, inclusive do Santos, que me emprestou trezentos mil-réis, e o Benedito imprimiu-o (DI, p. 181 - março de 1916).

Em nota precedente a essa citada, Lima queixa-se da má sorte, pois o momento em que seu livro foi publicado (26 de fevereiro de 1916) coincidiu, primeiro com a época do carnaval, depois Portugal declarara guerra à Alemanha (I Guerra Mundial), logo os jornais focaram a atenção nesses fatos e 
se esqueceram de falar de seu livro. Chegou a anotar os jornais cariocas que nada noticiaram a respeito, a saber: o Correio da Manhã e a Tribuna.

Em seguida à apresentação do "Diário Extravagante", Lima apontou o seu decálogo: "1 - Não ser mais aluno da Escola Politécnica. 2 - Não beber excesso de cousa alguma. 3 - E ..." (DI, p. 33 - 1903). O curioso decálogo de apenas dois mandamentos, já que o terceiro fica em suspenso pelas reticências, pode assinalar o abatimento desse eu que, de antemão, sabia da dificuldade em cumprir esses e outros possíveis mandamentos. No Diário do Hospício, dezessete anos depois, Lima voltaria a referir-se a esse decálogo:

Saído dela [da leitura de Le crime et La folie, de Maudsley], escrevi um decálogo para o governo da minha vida; entre os seus artigos havia o mandato de não beber alcoólicos, coisa aconselhada por Maudsley, para evitar a loucura. Nunca o cumpri e fiz mal (BARRETO, 2010a, p. 60).

Nesse contexto, o sofrimento natural dessa dificuldade de cumprir os mandamentos pode ser encarado a partir de duas perspectivas - a da renúncia de projetos e a da frustração de não conseguir alcançar algo desejado, seja em virtude de circunstâncias externas ou internas. A primeira diz respeito à dificuldade em cumprir o mandamento número um, abandono do sonho de se tornar engenheiro; a segunda, à dificuldade de deixar a bebida. Como sabemos, Lima conseguiu cumprir, cremos que não sem tristeza, apenas o primeiro item de seu decálogo.

Um olhar, ainda que rápido, nas primeiras notas de 1903, percebe um gosto fortemente acidulado, que exprime o dissabor do eu confessional: 
dar as aulas, cujo pagamento tem sido para mim sempre uma hipótese. Tomei café. Escrevi o memorial para o Serrado. Não o achou bom e eu sou da opinião dele.

Continuo a pensar onde devo comer. Há chance de ser com o Ferraz. Ah! Santo Deus, se depois disso não vier um futuro de glória, de que me serve viver? Se, depois de percorrido esse martirológio, eu puder ser mais alguma cousa do que o [i]diota Rocha Faria - antes morrer. [...]

Noite. Ainda não jantei. Às seis horas, com um tostão, comi uma empada. Que delícia! Ah! Se o futuro... (DI, p. 33-34 - 12 de junho de 1903).

Encontram-se nesse excerto alguns dos assuntos recorrentes nas páginas do diário - a falta de dinheiro, o ofício de escritor, a casa, o anseio por glória - abordados sempre a partir de uma perspectiva negativista. Na ocasião dessa nota, Lima ganhava a vida como professor particular, além de escrever para jornais. Nesse mesmo ano, candidatou-se a uma vaga para amanuense da Secretaria de Guerra, classificado em segundo lugar, acabara sendo nomeado em função do falecimento de um dos funcionários desse órgão.

Lima expressou ser seu objetivo principal ao escrever o Diário o de registrar suas ideias. De fato, ao longo dessa obra, ele expôs suas reflexões mais íntimas, seus desejos e anseios, os quais podem ser resumidos com palavras do próprio autor:

(...) que Deus me dê felicidade suficiente para pagar tudo que meu pai deve. E se eu isso fizer e se conseguir cercarIhe o resto da vida da abundância que ele tem direito, eu só peço três coisas:

Um amor

Um belo livro

E uma viagem pela Europa e pela Ásia (DI, p. 96 - 30 de janeiro de 1905).

Ultimo dia do mês em que, com certa regularidade, venho tomando notas diárias da minha vida, que a quero grande, nobre, plena de força e de elevação (DI, p. $96-31$ de janeiro de 1905). 
Destacam-se no Diário as anotações relativas aos fatos miúdos do cotidiano, ao comportamento de muitos de seus contemporâneos, às impressões de leituras, ao aperto do orçamento doméstico, à relação avessa com a família, às inquietudes em relação ao futuro. Tangenciando todas essas anotações, pulveriza as páginas íntimas o sofrimento em virtude de sua condição racial: "É triste não ser branco" (DI, p. 130 - 24 de janeiro de 1908), exclamava ele.

Acompanhamos vários desabafos de Lima lamentando a vida que levava, sentia-se essencialmente desajustado no seio familiar: "Dolorosa vida a minha! Empreguei-me e há três meses que vou exercendo as minhas funções. A minha casa ainda é aquela dolorosa geena pra minh'alma. É um mosaico tétrico de dor e de tolice" (DI, p. 41 - janeiro de 1904). Esse sentimento lastimoso em relação à família perdura por toda a existência de Lima, cristalizando-se de maneira aterradora ao longo dos anos de escritura do Diário: "A minha vida de família tem sido uma atroz desgraça. Entre eu e ela há tanta dessemelhança, tanta cisão, que eu não sei como adaptar-me. Será o meu 'bovarismo'?" (DI, p. $91-26$ de janeiro de 1905). O termo bovarismo, originário do francês bovarysme, formulado por Jules Gaultier (1858-1942) com base no romance Madame Bovary (1857) de Flaubert (1821-1880), segundo o dicionário Houaiss (2003) significa: "1. Tendência que certos indivíduos apresentam de fugir da realidade e imaginar para si uma personalidade e condições de vida que não possuem, passando a agir como se as possuíssem; 1.1 p. ext. faculdade que tem o ser humano de se conceber diferente do que é". Ora, Lima percebeu a possibilidade de estar alimentando a respeito de si uma ilusão, ao enxergar-se tão dessemelhante em relação a sua família. Eis aí 
esboçada a faceta do eu doméstico nesse terreno biográfico, sempre movediço, onde quanto mais nos metemos a cavar, mais difícil de mensurar se torna. Temos então a faceta de um eu pretensamente ilusório, criado a fim de satisfazer a ambição daquele, cujas aspirações estavam distantes do permitido pelas condições sociais ocupadas por aquele que seria o eu social.

Diante de confissões tão consternadas presentes nas páginas de Lima é possível pensarmos que, para ele, escrever um diário seria um meio de exteriorizar suas angústias. Desse modo, a necessidade de desabafo estaria estreitamente ligada ao sentimento de que os fatos cotidianos eram difíceis de suportar, escrever seria antes de tudo uma forma de aliviar toda essa tensão que tanto Ihe afligia. O diário serviria como espécie de refúgio às pressões cotidianas. Contudo, somente o ato da escrita não lhe bastou - o álcool foi outro consolo encontrado para se alienar da realidade: "[v]ai me faltando a energia. Já não consigo ler um livro inteiro, já tenho náuseas de tudo, já escrevo com esforço. Só o álcool me dá prazer e me tenta ... Oh! Meu Deus ! Onde irei parar?" (DI, p. 136 - 16 de julho de 1908), questiona-se aos vinte e sete anos.

Essa necessidade de expressão autobiográfica transbordou das páginas do diário à medida que Lima se serviu de material biográfico para compor a trama de seus romances realizando, no dizer de Hidalgo, a travessia da escrita de si para a literatura de si:

Todo o seu mal-estar consigo próprio e, a partir daí, com a sociedade rendeu uma surpreendente literatura de si que por vezes até parecia partir de um certo egocentrismo, mas almejava o coletivo. Ou o oposto: por ele ser refém do coletivo - ao nascer como depositário de preconceitos sociais da sociedade branca e burguesa, marcado pela pele negra, pela 
origem pobre e, em seguida, pela internação no hospício buscava uma literatura aparentemente egocêntrica para compreender-se, num mundo que se apresentava hostil desde o nascimento (HIDALGO, 2008, p. 93).

O testemunho pessoal, espécie de protesto, encontrou na forma do diário íntimo o meio mais justo para extravasar esse mal-estar sentido por Lima. Ressoaram desse espaço queixas e fracassos, desabafos e lamentos, em tom amargo de quem dificilmente teria seu talento aproveitado. Nesse cenário, faz-se interessante observar a alternância entre auto-elogio e autodesprezo, quando em alguns momentos Lima exaltou suas qualidades intelectuais e, em outros, assumiu-se enquanto fracassado. A respeito desse aspecto, resumiu ele: "Quando me julgo - nada valho; quando me comparo, sou grande. Enorme consolo" (DI, p. 52 - 26 de dezembro de 1904). Quatro anos mais tarde, revelou ser o que mais o atormentava sentir não ser inteligente, uma vez que "mulato, desorganizado, incompreensível e incompreendido, era a única coisa que [0] encheria de satisfação, ser inteligente, muito e muito!" (DI, p. 135 - 16 de julho de 1908). Hossne, assim caracterizou a posição de Lima:

\begin{abstract}
Um dos traços que mais chama a atenção de quem se aproxima da obra de Lima Barreto é a constância com que o autor expressa a desconfiança sobre sua capacidade literária, mesmo que ao lado desta não faltem exclamações orgulhosas sobre sua potencialidade criativa (HOSSNE, 1999, p. 210).
\end{abstract}

Consciente do valor social concedido àqueles reconhecidos intelectualmente, Lima almejou sobremodo ser aplaudido por sua inteligência. Não à-toa mandou traduzir, por tradutor juramentado, carta recebida pelo historiador Capistrano de Abreu (1853-1927) do presidente da Universidade 
Stanford, na qual o tal sábio americano, brevemente, se disse satisfeito da obra Vida e Morte de M. J. Gonzaga de Sá e agradeceu o envio. A reprodução dessa carta nas últimas páginas do Diário (p. 214) é reveladora desse apelo à glória que ressona como um ruído mais ou menos vibrante do início ao fim das páginas íntimas. Haja vista, nesse sentido, o grande projeto limabarretiano de escrever seu Germinal negro que o traria talvez uma "fama europeia" (DI, p. 84 - 12 de janeiro de 1905). As duas candidaturas à Academia Brasileira de Letras em 1917 e, posteriormente, em 1919 confirmam uma vez mais esse desejo de Lima de ser agraciado como intelectual.

O deslocamento cultural sentido pelo autor, em razão da falta de consonância entre o espaço exterior onde vivia e seu interior, pode ter sido outra razão que o impulsionou a escrever um diário íntimo, segundo Coutinho (op. cit., p. 593) "forma de diário escrita secretamente". Acerca do desajustamento do sujeito face ao mundo, Didier apontou ser algo recorrente na esteira diarista, embora não seja uma regra.

Ser opositor é colocar-se, é, portanto, escapar dessa vertigem, dessa não inserção absoluta que é quase sempre um elemento do "diarismo", se podemos arriscar uma expressão que pretende ao mesmo tempo poder caracterizar uma tendência literária e uma espécie de doença (DIDER, op. cit., p. 70, tradução nossa) ${ }^{26}$.

Por meio da palavra tentou expressar o sentimento de desajuste intensificado ainda mais por ser, a nosso ver, duplo, uma vez que não se identificava com o meio onde vivia, pois se sentia superior em relação aos

\footnotetext{
${ }^{26}$ Texto original: « Être opposant, c'est se poser, c'est donc échapper à ce vertige, à cette noninsertion absolue qui est presque toujours un élément du "diarisme » si l'on peut risquer une expression qui voudrait à la fois pouvoir caractériser une tendance littéraire et une sorte de maladie » (DIDER, op. cit., p. 70).
} 
familiares e, ao mesmo tempo, não conseguia ajustar-se aos padrões da sociedade. Dotado de uma verve crítica, nenhum setor social escapou à sua pena: "[é] notório que aos governos da República do Brasil faltam duas qualidades essenciais a governos: majestade e dignidade" (DI, p. 48 - 1904). Postura que acabou por relegá-lo à margem do reconhecimento tão desejado, visto esse eu social tornar-se cada vez mais imperativo, buscando sempre um outro lugar isento de mesuras sociais onde pudesse exprimir-se livremente. Daí decorreu a opção por um diário delineado "extravagante" pela visada crítica que adotou para comentar os fatos. Referiu-se, por exemplo, do seguinte modo ao analisar os acontecimentos decorrentes da Revolta da Vacina (1904):

Eis a narrativa do que se fez no sítio de 1904. A polícia arrepanhava a torto e a direito pessoas que encontrava na rua. Recolhia-as às delegacias, depois juntavam na Polícia Central. Aí, violentamente, humilhantemente, arrebatava-lhes os cós das calças e as empurrava num grande pátio. Juntadas que fossem algumas dezenas, remetia-as à ilha das Cobras, onde eram surradas desapiedamente. Eis o que foi o Terror do Alves; o do Floriano foi vermelho; o do Prudente, branco, e o Alves, incolor, ou antes, de tronco e bacalhau (DI, p. 49 - Sem data, 1904).

Consciente de sua extravagância ao julgar fatos e pessoas, Lima declarou, logo em seguida à nota supracitada: "[e]ste caderno esteve prudentemente escondido trinta dias. Não fui ameaçado, mas temo sobremodo os governos do Brasil" (DI, p. 49 - Sem data, 1904). Sempre inquisidor, traz a tona uma realidade dissimulada pelos governantes, como a discussão do lugar do negro em nosso país, temática que será abordada no último capítulo. A conduta de Lima leva-nos a perceber que ele provocou seu lugar social à medida que assumiu posição de enfrentamento, continuando a escrever privilegiando temas difíceis de serem digeridos pela nossa elite. Eliminou o 
protocolo e a pose intelectual, antecipando traços que viriam a ser próprios dos modernistas, a exemplo de Oswald de Andrade.

De modo escapista, como Lima não tinha com quem compartilhar seus desgostos, recorreu às páginas de um diário para amenizar sua dor. A realidade é que ele tinha poucos amigos, como assinalou Barbosa (op. cit., p. 156): "[p]oucas eram as casas que visitava - e assim mesmo nos tempos da primeira mocidade". Entre os amigos destacaram-se Noronha Santos, Otávio Carneiro e os irmãos Gomes Carneiros ${ }^{27}$. Em 1908, Lima confessou abatê-lo não ter amigos e perder os poucos que tinha: "Santos está se afastando; Ribeiro e J. Luís também. Eram os melhores. Carneiro, (o Otávio), o egoísta e frio Otávio, está fazendo a sua alta vida, a sua reputação, o seu halo grandioso, e é preciso não me procurar mais" (DI, p. 136 - 16 de julho de 1908). E completa essa nota expressando sua solidão: "Eu fico só, só com os meus irmãos e o meu orgulho e as minhas falhas" (DI, p.136 - 16 de julho de 1908). Além das raras amizades, esse sentimento de solitude foi talvez agravado pelo fato de Lima, pelo que se sabe, não ter mantido relacionamentos amorosos significativos. No Diário, há algumas situações de flertes, como no trecho abaixo em que Lima, na ausência do amigo a quem fora visitar, acabou interessando-se pela mulher do mesmo:

Em começo, tive uma alegria de devasso - quem sabe? - que passou depressa e felizmente. Ela sentou-se na minha frente,

\footnotetext{
${ }^{27}$ Noronha Santos (1876-1954) foi um historiador brasileiro. Manuel Otávio de Sousa Carneiro (1881-1920) foi um engenheiro e político brasileiro. Formou-se pela Escola Politécnica do Rio de Janeiro. Antônio Ernesto Gomes Carneiro (1846-1894) foi um militar brasileiro, que teve ativa participação na Guerra do Paraguai e na Revolução Federalista. Foi aluno da Escola Militar do Rio de Janeiro.
} 
fumei desesperadamente e conversei. Nunca estive tão bem. Tenho vinte e seis anos e, até hoje, ainda não me encontrei com uma mulher de qualquer espécie de maneira tão íntima, de maneira tão perfeitamente a sós; mesmo quando a cerveja, a infame cerveja, me embriaga e me faz procurar fêmeas, é um encontro instantâneo, rápido, de que saio perfeitamente aborrecido e com a bebedeira diminuída pelo abatimento $(D I, \mathrm{p}$. 126 - 05 de janeiro de 1908, grifos nossos).

Tal encontro não passou de uma longa conversa, ainda assim, dá a impressão de ter causado certo deslumbramento em nosso tímido conquistador. Esse trecho deixa claro o tipo de relação que Lima mantinha com mulheres, encontros instantâneos, rápidos. Dez anos depois, relatou outra situação de namorico:

Eu beijei por uma ou duas vezes E., cunhada do H. M. Isto foi há dias e eu estava esquentado. Se aquela ocasião fosse propícia, talvez consumássemos 0 ato. Ela é casada com um demônio de um inferior da Marinha, estúpido a roçar na idiotice. Tem todas as manifestações da compressão militar, em que o puseram desde a meninice. Tem dous filhos.

A E. não é uma beleza, mas é farta de carnes e tem aquele capitoso das caboclas, quando moças. Foi sempre ela quem me provocou. Naquele dia, eu fui adiante... O G. a ronda também, mas penso que não chegou tão longe...

O que eu queria dizer é que, agora, quase um mês passado, eu não tenho nenhum interesse em continuar a aventura. Não lhe tenho amor, não me sinto atraído por ela, por isso não encontro justificativa em mim mesmo para arrastá-la, como se diz, a um mau passo. Havemos de ver... (DI, p. $197-21$ de janeiro de 1918, grifos nossos).

Ao que parece, Lima procurava mulheres em momentos de êxtase seja pela falta de controle em razão da embriaguez ou de irritação, conforme ambas as descrições citadas deixam entrever em nossos grifos. Desse último excerto, vale ressaltar que Lima não amava essa mulher, por isso mesmo, passado alguns dias, decidiu não levar adiante essa relação. Surgiu do sentimento de solidão, a necessidade de recorrer ao diário, consolo a esse sujeito apartado. 
Nesse sentido, no Diário encontramos uma tentativa de interlocução consigo, dito de outro modo, nesse movimento Lima narrador colocou-se como objeto e sujeito de seu olhar nos momentos de introspecção do indivíduo Lima Barreto: "[o diário] [é], em primeiro lugar, uma espécie de desdobramento do seu autor, um ver-se em terceira pessoa, embora os diários sejam escritos em primeira" (AGUIAR; MEIHY; VASCONCELOS, op. cit., p. 165). No caso de Lima, os esboços de romance podem indicar muito mais que dois personagens focalizados - aquele que é matéria narrativa e narrador - já que o autor personificou outros tantos personagens por meio da elaboração ficcional. Sob esse prisma, as afinidades entre o eu confessional e os personagens por ele criados parecem querer dar conta de uma identidade composta de elementos diversos relacionados entre si, cuja expressão tenta se dar através da escrita. Daí decorre nossa dificuldade em contornar esse eu, por assim dizer, inapreensível, aspecto intrínseco à natureza humana.

Porém, uma vida humana não se reduz a uma estrutura axiomática; responde a uma inteligibilidade intrínseca, regida por afinidades, harmonias e oposições, complementaridades, para aqui ou para além das formalizações racionais. As grandes autobiografias são as que melhor exprimem esses ritmos da vida, sincretismos e alternâncias, indicativos de uma unidade que se anuncia e se enuncia sem nunca deixar-se reduzir às dimensões de um discurso escrito, tão genial ele seja, segundo a ordem de uma verdade maciça e monolítica (GUSDORF, op. cit., p. 315, tradução nossa) ${ }^{28}$.

\footnotetext{
${ }^{28}$ Texto original: «Mais une vie humaine n'est pas reductible à une structure axiomatique; elle répond à une intelligibilité intrinsèque, régie par des affinités, harmonies et oppositions, complémentarités, en déça et au-délà des formalisations rationnelles. Les grandes autobiographies sont celles qui expriment le mieux ces rythmes de la vie, syncrétismes et alternances, indicatifs d'une unité qui s'annonce et s'énonce et se dénonce sans jamais se laisser réduire aux dimensions d'un discours écrit, si génial soit-il, selon l'ordre d'une vérité massive et monolithique » (GUSDORF, op.cit., p. 315).
} 
Diante disso, por mais que o narrador do Diário fale de uma esfera privada, refletindo acerca dos fatos externos a partir de uma perspectiva subjetiva, além de expor seus pontos fracos, seu discurso tende a reconstituir o homem Lima Barreto à sua própria semelhança é verdade, mas sem jamais dimensioná-lo exatamente. O modo como esse narrador se posicionou marca a presença de um eu confessional, limitado quase que exclusivamente às suas percepções, sentimentos e pensamentos, talvez em busca de transformar essa matéria-prima numa obra-prima capaz de pintar outra imagem de seu autor.

Ainda que no diário íntimo prevaleçam notas introspectivas de um eu mergulhado nele mesmo, não podemos ignorar a presença do outro permeando as notas a todo instante. Seria fácil multiplicar as citações pinçadas ao acaso no diário de Lima que, frequentemente, comentou aspectos pitorescos do comportamento e da personalidade daqueles com quem convivia. A imagem do outro, quase sempre, foi por ele delineada a partir de um ponto de vista crítico e sarcástico. Vejamos, a título de exemplo, comentário sobre seu tio Barbosa de Lima:

\footnotetext{
O Barbosa Lima descompôs o Medeiros; não há negar que o Medeiros é vil como uma serpente, mas o Barbosa tem sido de uma felicidade pasmosa, tendo sempre como adversário fofos literatos (no mau sentido!), que não podem arrancar-Ihe aquela máscara de matemático e de filósofo.

É um péssimo espírito esse Barbosa Lima, utópico, granítico, recheado de positivismo, cheio de idéias sentimentais, mas no fundo cruel e covarde moral. É uma das mais belas flores do bacharelismo do Exército, bacharelismo cheio de espírito de casta e de fofa ciência. Convém debicá-lo ( $D I$, p. 43-44-28 de outubro de 1904).
}

Agora num movimento contrário, paramos aqui para refletir acerca do modo como Lima disse ser visto pelo outro, dado a subjetividade da escrita 
diarista. Da imagem de si impressa em suas notas destacaram-se os traços negros - o estigma racial parece ter servido continuamente para caracterizá-lo.

\begin{abstract}
Hoje, comigo, deu-se um caso que, por repetido, mereceu-me reparo. la eu pelo corredor afora, daqui do Ministério, e um soldado dirigiu-se a mim, inquirindo-me se era contínuo. Ora, sendo a terceira vez, a cousa feriu-me um tanto a vaidade, e foi preciso tomar-me de muito sangue frio para que não desmentisse com azedume. Eles, variada gente simples, insistem em tomar-me como tal, e nisso creio ver um formal desmentido ao professor Broca (de memória). Parece-me que esse homem afirma que a educação embeleza, dá, enfim, outro ar à fisionomia. Porque então essa gente continua a me querer contínuo, porque? Porque... o que é verdade na raça branca, não é extensivo ao resto; eu, mulato ou negro, como queiram, estou condenado a ser sempre contínuo (DI, p. 51-52 - 26 de dezembro de 1904).
\end{abstract}

Como se sabe, Lima ocupava o cargo de amanuense na Secretaria de Guerra, espécie de secretário. Porém, fora tomado por contínuo, função mais subalterna àquela por ele exercida; diz respeito àquele que faz trabalhos de entregas. O motivo de tal equívoco é por ele mesmo respondido. Reconheceu que, embora letrado, pesariam sobre ele as origens raciais. A forma como Lima vê o outro se liga mais ou menos ao modo como é visto. Em alguma medida, isso justifica a postura ofensiva que manteve. $O$ ataque, então, seria uma estratégia de defesa, pois ao apontar as falhas do outro se equalizam as imperfeições. Esse tema da questão racial será aprofundado mais adiante no terceiro capítulo dessa dissertação.

O outro se fez presente também por meio da reprodução de diálogos, seja de conversas ouvidas por Lima no bonde, na Secretaria; seja de conversas das quais participou. Sublinhamos a reprodução do diálogo entre Lima e a mulher de um conhecido, cujo nome foi mantido em secreto, na ocasião de uma visita feita em que o tal amigo encontrava-se ausente, episódio 
anteriormente citado. $O$ relato desse momento configura-se de grande elaboração criadora, serviu como objeto de análise a Candido (2006, p. 47-60) no ensaio "Os olhos, a barca e o espelho".

Em tese, sabemos que o diário não visa publicação, contudo, a perspectiva de ser lido mantém-se no horizonte de quem o escreve. Em uma das passagens do Diário observamos um desejo velado do autor em estabelecer certa interlocução com possíveis leitores de suas páginas.

\begin{abstract}
Se essas notas forem algum dia lidas, o que eu não espero, há de ser difícil explicar esse sentimento doloroso que eu tenho de minha casa, do desacordo profundo entre mim e ela; é de tal forma nuançoso a razão de ser disso, que para bem ser compreendido exigiria uma autobiografia, que nunca farei. Há cousas que sentidas em nós não podemos dizer. [...] Hoje, pois, como não houvesse assunto, resolvi fazer dessa nota uma página íntima, tanto mais íntima que é de mim para mim, do Afonso de vinte e três anos para o Afonso de trinta, de quarenta, de cinqüenta anos. Guardando-as eu poderei fazer delas como pontos determinantes da trajetória da minha vida e do meu espírito, e outro não é o meu fito $(D I$, p. $77-3$ de janeiro de 1905).
\end{abstract}

Logo, não ignorava a possibilidade de ser lido na posteridade. E completou, aconselhando aos leitores: "Aqui bem alto declaro que, se a morte me surpreender, não permitindo que as inutilize, peço a quem se servir delas que se sirva com o máximo cuidado e discrição, porque mesmo no túmulo eu poderia ter vergonha" (DI, p. $77-3$ de janeiro de 1905). Aqui, é pertinente refletirmos sobre um aspecto apontado por Aguiar referente aos escritores que se serviram desse gênero: "Escreve diário aquele que não sabe se ou como vai durar" (AGUIAR; MEIHY; VASCONCELOS, op. cit., p. 166). Ora, sabemos que a vida de Lima não era nada tranquila, boêmio, atormentado pela falta de dinheiro, preocupado com a família, consumia-se pouco a pouco pela vida 
desregrada que levava. Já em 1908 confessou que apenas o álcool dava-lhe prazer e o tentava, acompanhamos os efeitos das sucessivas bebedeiras ligadas, como se pode observar nas notas dos diários, ao fracasso de seus projetos e apreensões familiares.

Não tenho editor, não tenho jornais, não tenho nada. O maior desalento me invade. Tenho sinistros pensamentos. Ponho-me a beber; paro. Voltam eles e também um tédio da minha vida doméstica, do meu viver cotidiano, e bebo. Uma bebedeira puxa outra e lá vem a melancolia. Que círculo vicioso! (DI, p. $171-20$ de abril de 1914, grifos nossos).

Dessa nota, escrita quatro meses antes de sua primeira entrada no Hospício, ecoa latente negativismo, evidenciado de chofre pela repetição do advérbio não por três vezes numa única sentença, por nós sublinhado. As palavras escolhidas por Lima a fim de descrever seu estado de alma - maior desalento, sinistros pensamentos, tédio, melancolia - enfatizam o abatimento desse eu que gradualmente se distanciava do sonhado futuro glorioso. Como se verá esse estado de desalento agravar-se-á dia após dia.

Hoje, depois de ter levado quase todo o mês passado entregue à bebida, posso escrever calmo (DI, p. $191-03$ de junho de 1917).

De há muito sabia que não podia beber cachaça. Ela me abala, combale, abate todo o organismo, desde os intestinos até à enervação. Já tenho sofrido muito com a teimosia de bebê-la. Preciso deixar inteiramente.

No dia 30 de agosto de 1917, eu ia para a cidade, quando me senti mal. Tinha levado todo o mês a beber, sobretudo parati. Bebedeira sobre bebedeira, declarada ou não. Comendo pouco e dormindo sabe Deus como. Andei porco, imundo ( $D I$, p.193 05 de setembro de 1917).

Não é de se estranhar, portanto, a segunda internação no Hospício dois anos depois dessas notas. O diagnóstico de ambas as reclusões foi o mesmo - 
alcoolismo. Da cópia de seus prontuários, destacaram-se os sintomas de perturbações mentais - "aparecimento de fantasmas", delírios "de caráter terrificante, perseguidor" (BARBOSA, op. cit., p. 370). Antes mesmo da primeira internação, Lima observou: "Noto que estou mudando de gênio. Hoje tive um pavor burro. Estarei indo para a loucura?" (DI, p. 172 - 13 de julho de 1914), o abuso do álcool levou-o a sofrer de alucinações. Esse fato nos remete à função psicanalítica do diário - seria um meio de exteriorizar esses fantasmas que o perseguiam. Vale conferir, nas palavras de Gusdorf, o papel psicoterapêutico das escritas do eu:

Em todos os casos possíveis e não importa a natureza particular dos documentos em questão, a escrita é uma psicoterapia, um fator de equilíbrio. Mesmo a ideia de consciência implica um contato de si para si, um consentimento entre o estado de espírito momentâneo e a personalidade; a presença no mundo se funda sobre ela, e encontra nesse fundamento uma nova segurança. A escrita consagra um desdobramento da consciência primeira, uma segunda consciência consagrada pela inscrição consolidada pela palavra. Toda escrita do eu institui um abrigo do eu, um lugar onde o espírito pode retomar ar, tomar distância de si, ponto de apoio, ainda que passageiro, como aquele que concede o bastão ao caminhante (GUSDORF, op. cit., p. 337-338, tradução nossa) ${ }^{29}$.

Nessa perspectiva, podemos pensar que Lima, ao escrever seu diário, manteve-se livre dos delírios à medida que se apoiou na escrita para tentar remediar o turbilhão interior que o conduzia à insanidade. Exercício que mobilizou suas paixões, no sentido etimológico originária de pathos,

\footnotetext{
${ }^{29}$ Texto original: «Dans tous les cas possibles, et quelle que soit la nature particulière des documents en question, l'écriture est une psychothérapie, un facteur d'équilibre. L'idée même de conscience implique un contact de soi à soi, un consentement entre l'état d'esprit momentané et la personnalité; la présence au monde se fonde sur elle même, et trouve dans ce fondement une assurance neuve. L'écriture consacre un redoublement da la conscience première, une seconde conscience consacrée par l'inscription qui consolide la parole. Tout document du moi institue un reposoir du moi, un lieu où l'esprit peut reprendre haleine, prendre ses distances par rapport à soi, point d'appui, même passager, comme celui qui procure le bâton au marcheur » (GUSDORF, op.cit., p. 337-338).
} 
exteriorizadas no divã da página branca.

Ao compararmos as características formais típicas do diário íntimo, descritas na primeira parte desse capítulo, com a constituição do Diário de Lima, vemos que este responde às particularidades do gênero à medida que apresenta semelhantes traços formais - narrador em primeira pessoa, reflexão pessoal acerca dos fatos da realidade cotidiana, exposição das fraquezas do eu, apelo à glória, justificando, portanto, o título concedido por Barbosa.

A respeito das motivações que levam alguém a escrever um diário, observamos que o perfil, bem como a trajetória de Lima corresponde à tipicidade dos diaristas, levados a escrever, em geral, por uma experiência de padecimento. Nesse sentido, o diário, conforme vimos, pode cumprir a função psicanalítica de cura interior, amenizando o sofrimento por meio dos desabafos íntimos. Configura-se também o lugar de refúgio do eu, desorientado diante de si, do outro, do mundo. Ora, o diário de Lima, certamente, exerceu papel análogo, evitando talvez maiores arroubos de embriaguez. Porém, cabe uma ponderação no que concerne à ideia de refúgio, lugar comumente usado por aqueles que desejam fugir de uma situação adversa. No caso de Lima que se propôs intencionalmente a escrever um diário de caráter "extravagante", o refúgio veio à revelia, configurou-se por amparar um eu contestador que não se convencia da organização social imposta pela intelligentsia da qual, por sinal, não fazia parte. A maneira como encarou o gênero diário relaciona-se intimamente com sua conduta na vida literária, considerada "extravagante" por focalizar em sua produção ficcional temas incômodos da vida social brasileira, a exemplo do tratamento dispensado aos negros e mestiços.

Tal como uma trincheira, o diário, uma vez segredado, serviu à posição 
de ataque voraz sustentada por Lima ao mesmo tempo em que o protegeu de maiores revides nesse campo social de batalha. Refugiado nele, portanto, pôde extrapolar padrões intelectuais, sociais, literários, nesse espaço cavado pela aporia de um eu marcado pela opressão e pela exclusão. Assim, num balanço oscilante muito mais para baixo do que para cima, no qual Lima jamais conseguiu equilibrar-se, conjugou a forma europeia com sua singular extravagância conforme aquilo que desejou ou não revelar e marcar secretamente de suas opiniões, desejos e fracassos por meio da escrita confessional. Construiu, assim, um diário original. É possível dizer que esse diário tornou-se íntimo por ter nascido "extravagante", haja vista a pretensa inconveniência de suas notas alinhavadas de modo sinuoso por claros fios de plena lucidez, por esse escritor que não se alinhou linearmente à sociabilidade literária de seu tempo. Passemos, pois, a observá-lo nos cenários por onde se movimentou atentando para o modo como figurou socialmente em cena. 
Capítulo II O Rio de Janeiro no limiar do século XX - Lima Barreto em Cena

"No curso da vida e das leituras."

(Diário Íntimo) 


\title{
2. O Rio de Janeiro no limiar do século XX - Lima Barreto em Cena
}

A capital da República - a cidade do Rio de Janeiro - no início do século $\mathrm{XX}$, período conhecido como Belle Époque, caracterizou-se por uma nova sociabilidade advinda da modernização do espaço urbano, promovida pelas reformas instauradas por Rodrigues Alves $(1848-1919)^{30}$, realizadas a partir do planejamento do então prefeito dessa cidade, o engenheiro Pereira Passos ${ }^{31}$ (1836-1913). O objetivo era o de colocar o país nos trilhos da civilização. Por aqueles tempos, vale frisar, "civilização e progresso eram em geral vistos de uma perspectiva francesa" (NEEDELL, 1993, p. 66).

De fato, as transformações estruturais passadas pelo Rio de Janeiro podem ser percebidas nas anotações de Lima Barreto, ao longo dos anos de escritura do Diário Íntimo.

\begin{abstract}
Saí e tomei um bonde e fui a Prainha. A rua está outra, não a conheci bem. Se os prédios fossem mais altos, eu me acreditaria em outra cidade. Estive na esquina dela com a avenida, a famosa avenida das indenizações, subi-a a pé, tomei pelo que resta de beco da Rua da Prainha, agora em alargamento, e segui pela Rua Larga de São Joaquim, prolongada e alargada até o Largo de Santa Rita. A rua quebra um pouco do primitivo alinhamento, mas mesmo assim ficará bela. Entretanto, como vêm já de boa administração essas modificações, acredito que o Rio, o meu tolerante Rio, bom e relaxado, belo e sujo, esquisito e harmônico, o meu Rio vai perder, se não lhe vier em troca um grande surto industrial e comercial; com ruas largas e sem ele, será uma aldeia pretensiosa de galante e distinta, como é o tal de São Paulo (DI, p. 91-2 - 27 de janeiro de 1905).
\end{abstract}

\footnotetext{
${ }^{30}$ Foi o quinto presidente do Brasil, seu mandato compreendeu os anos de 1902 a 1906.

${ }^{31}$ Nomeado prefeito pelo presidente Rodrigues Alves, ao lado de Lauro Müller, Paulo de Frontin e Francisco Bicalho, promoveu uma grande reforma urbanística na cidade, com o objetivo de saneá-la e urbanizá-la. Esse período ficou conhecido como "Bota-abaixo", devido as grandes transformações estruturais. É notável registrar que Pereira Passos estudara engenharia na França e assistira à reforma urbana de Paris sob o comando do barão de Haussmann, para a reurbanização dessa cidade.
} 
O alargamento das ruas descritas, conforme se pode observar, chamou muito a atenção de Lima que pareceu não ver com bons olhos tais modificações, que descaracterizariam a paisagem do Rio, tornando-o semelhante à cidade paulistana. Esse aspecto - alargamento e abertura de ruas -, com efeito, foi uma marca das medidas implementadas pela administração de Pereira Passos, norteado pelas reformas da capital francesa.

[...] os princípios que haviam orientado as Grandes Obras parisienses foram adaptadas ao Rio. As demolições na Cidade Velha rivalizaram com a destruição dos bairros proletários por Haussmann. A ênfase na iluminação e na ventilação, por meio de ruas alargadas e novas vias, foi fundamental em ambas as reformas (NEEDELL, op. cit., p. 57).

Na esteira das modernizações, em 1904, inaugurou-se a Avenida Central (atual Avenida Rio Branco). Símbolo da nossa Belle Époque, "[ess]a avenida era a peça central das reformas cariocas e, como tal, representava as aspirações de Progresso e Civilização do país" (Ibid., p. 65).

O Rio civilizava-se ganhando ares parisienses - imponentes prédios foram construídos, estátuas e monumentos foram edificados, ruas foram criadas, outras ampliadas. Assim, em 1908, inauguraram-se as instalações da Escola Nacional de Belas-Artes, no ano seguinte, seria a vez do edifício do Teatro Municipal, seguido pelo da Biblioteca Nacional, em 1910. A formulação de Carvalho dimensiona o prestígio gozado pela capital nacional nesse período:

O Rio de Janeiro dos primeiros anos da República era a maior cidade do país, com mais de 500 mil habitantes. Capital política e administrativa, estava em condições de ser também, pelo menos em tese, o melhor terreno para o desenvolvimento da cidadania. Desde a independência e, particularmente, desde o início do Segundo Reinado, quando se deu a consolidação do governo central e da economia cafeeira na província adjacente, 
a cidade passou a ser o centro da vida política nacional (CARVALHO, 1987, p. 13).

Além dessas mencionadas, outras reformas urbanísticas no centro da cidade forçaram os pobres a mudar-se para o subúrbio. Entrávamos na era do automóvel, das grandes avenidas. Nesse cenário, a vida social intensificou-se com a frequência nos chás, salões e confeitarias. Sublinhamos o mais elegante estabelecimento comercial de luxuosa decoração e riqueza da época, comparável às confeitarias de Paris e Londres: a Confeitaria Colombo. Fundada em 1894, pelos imigrantes portugueses Joaquim Borges de Meireles e Manuel José Lebrão, o espaço recebia célebres clientes: Chiquinha Gonzaga, Olavo Bilac, Rui Barbosa, Lima Barreto, José do Patrocínio, entre tantos outros. Permanece em atividade até os dias de hoje.

Lima não só nasceu nessa cidade como aí passou toda sua vida, portanto vivenciou as diversas transformações sofridas pela capital nacional não deixando de registrar no Diário os efeitos dessas mudanças.

Estado geral do Brasil nos começos do século XIX. Causas que obrigaram Dom João $\mathrm{VI}$ a partir para 0 Brasil. Desembarque. A cidade do Rio de Janeiro. Seu governo. Seus habitantes. Ruas e praças. Fisionômica. Em relação ao destino do Brasil, medidas tomadas logo pelo Regente. Escolas superiores. A colônia artística. A cultura musical. José Maurício. Criações políticas. Secretarias de Estado. Ministros. Construções. Criações de novas capitanias. Regímen das minas. Revoluções e guerra. A sedição de 1817 em Pernambuco. Expedição de Caiena. Modificações na vida comum. Aumento de esplendor. Teatros. Festas religiosas. Trajes. Arrabaldes. Vilegiaturas. Santa Cruz, ilha do governador, São Domingos. Caráter da edificação. Antes e pós Dom João VI. Monumentos deixados. Quinta da Boa Vista. Transformação. Museu Nacional. A família real. Os fidalgos, seu caráter P. R. (DI, p. 42 - Sem data, 1904).

Nessa sequência descritiva, construída por meio de frases curtas de 
efeito quase cinematográfico, pequenas cenas da história do Brasil são por Lima evocadas de modo que o leitor rapidamente tem uma ideia geral das modificações passadas pela cidade, após a chegada da Família Real, em 1808.

Durante o período que correspondeu à Primeira República (1889-1930), o Rio de Janeiro foi, sem dúvida, o mais importante centro político e cultural do país, haja vista a criação da Academia Brasileira de Letras em 1897, inspirada na Académie Française de Lettres (fundada em 1635), sendo assim uma instituição à la française. Considerado um pólo irradiador de cultura para as outras cidades do país, o Rio era o local onde as novidades europeias primeiramente chegavam para depois, em alguns casos, seguirem para as outras cidades brasileiras. Dito de outro modo, funcionou como uma porta de entrada, além de ser o símbolo da brasilidade, tanto no âmbito nacional, quanto internacionalmente. Logo, "à cidade pôde ser dado o papel de cartão-postal da República" (CARVALHO, 1987, p. 39). Sediava várias instituições de grande importância, como o Banco do Brasil, além de outros bancos nacionais e estrangeiros e a Bolsa de Valores, portanto concentrava as finanças nacionais. Era a maior cidade brasileira, sendo assim, oferecia mercado consumidor e mão-de-obra às indústrias. Na virada do século $\mathrm{XIX}$, o porto do Rio era o terceiro maior em volume de comércio no continente americano. Todavia, em virtude de ser a cidade do Brasil que concentrava o maior número de habitantes, possuía vários problemas estruturais que a tornavam insalubre e desordenada - ruas estreitas, doenças como a varíola e o impaludismo, grande número de pessoas vivendo miseravelmente amontoadas em cortiços. Foi diante desse quadro lastimável que se fez urgente mudar a imagem da capital da República acompanhando o progresso, que estava atrelado ao espírito 
francês da Belle Époque.

Na França, a Belle Époque situou-se ao longo dos anos de 1870 a 1914, momento de vertiginoso crescimento de algumas nações europeias. Surgiram novas descobertas e tecnologias, e o cenário cultural fervilhou com o aparecimento dos cabarés, do cancã, do cinema. Esse período foi marcado também por uma espécie de pacificação da vida cotidiana; caracterizado, portanto, por uma extrema joie de vivre (SILVA, 2006, p. 15-16). Paralelamente, nesse cenário, profundas transformações sociopolíticas marcaram o Velho Mundo - tivemos o nascimento do moderno imperialismo.

Em nossa versão tropical da Belle Époque, pairou uma atmosfera de certa euforia e esperança de um novo tempo esplendoroso que se acreditava advir. No plano político, o país entrava num período de relativa calma, depois de abafada a Revolta de Canudos $^{32}$. O regime republicano prometia a resolução dos conflitos entre conservadores e liberais. No plano econômico, a política de Campos Sales (1841-1913) ${ }^{33}$, encarregado de cuidar das finanças, oferecia novo alento após a experiência do Encilhamento ${ }^{34}$; e, no social, o médico sanitarista Oswaldo Cruz (1872-1917) iniciava a campanha da vacina obrigatória para extinção da febre amarela.

A Revolta da Vacina (1904), movimento que reuniu a massa popular para defender antes de tudo a moral e a honra das famílias diante da

\footnotetext{
${ }^{32}$ Vultoso conflito civil, iniciado em novembro de 1896, no sertão da Bahia, estendeu-se até outubro do ano seguinte. A Guerra de Canudos foi o enfrentamento entre os integrantes de um movimento popular de cunho sócio-religioso liderado por Antônio Conselheiro e as forças do Exército Brasileiro. Do confronto resultou a completa destruição do arraial de Canudos e o massacre de cerca de vinte mil sertanejos.

${ }^{33}$ Foi o quarto presidente do Brasil, seu mandato estendeu-se de 1898 a 1902.

${ }^{34}$ Grande especulação financeira durante o primeiro ano da República que culminou com a derrubada do preço das ações da Bolsa e a falência de bancos e empresas. Cf. Fausto, 2008, p. 252.
} 
obrigatoriedade que feria os direitos civis dos cidadãos (CARVALHO, 1987), foi objeto de reflexão de Lima que teceu comentário engajado reconhecendo a importância da participação popular, chegando mesmo a enaltecer a força do povo:

Durante as masorcas de novembro de 1904, eu vi a seguinte e curiosa coisa: um grupo de agentes fazia parar os cidadãos e os revistava. O governo diz que os oposicionistas à vacina, com armas na mão, são vagabundos, gatunos, assassinos, entretanto ele se esquece que o fundo dos seus batalhões, dos seus secretas e inspetores, que mantêm a opinião dele, é da mesma gente. Essa masorca teve grandes vantagens: $1^{1}$ ) demonstrar que o Rio de Janeiro pode ter opinião e defendê-la com armas na mão; $2^{a}$ ) diminuir um pouco o fetichismo da farda; $3^{a}$ ) desmoralizar a escola militar. Pela vez primeira, eu vi entre nós não se ter medo de homem fardado. O povo, como os astecas ao tempo de Cortés, se convenceu de que eles também eram mortais (DI, p. 47-8 - Sem data, 1904).

Das notas do Diário, transparece a sensibilidade intelectual de Lima no tocante aos novos rumos sociopolíticos direcionados pelas bandeiras da evolução e do progresso, sentido inexorável para constituir-se um país civilizado. Em 1906, quando muito provavelmente começara a redigir o romance Vida e morte de M. J. Gonzaga de Sá, acompanhamos, no esboço presente no Diário, as opiniões e ideias do personagem J. Gonzaga de Sá a respeito da geografia do Rio de Janeiro em relação a das demais cidades da Europa.

Nota-se que em geral as grandes cidades, especialmente as europeias, não têm um fundo de cordilheira como a nossa. Ora, se as grandes cidades não têm tal disposição natural e se o Rio quer ser das grandes à européia, deve arrasar as montanhas. Não há prejuízo algum com isso. A desvantagem única seria a supressão do Corcovado, montanha internacional e muito procurada pelos estrangeiros. Em substituição, pode-se erguer uma torre semelhante à Eiffel, em Paris. Até será muito 
melhor, pois ficará o Rio muito parecido com a capital da França. [...]

Nota-se também que as grandes metrópoles ficam sobre rios mais ou menos consideráveis (Paris, Berlin, Londres, New York, Viena, etc) - logo se o Rio quer ser grande metrópole deve ficar à margem de um rio respeitável. Poder-se-ia transformar o Maracanã em Rio considerável. Com canalizações suplementares às nascentes, o aumento do seu volume d'água poderia ser obtido; mas seria falsificar. O melhor é um rio autêntico e bem catalogado nas geografias. Nenhum mais adequado do que o Paraíba, para preencher um fim tão civilizador (DI, p. 119-120 - Sem data, 1906).

Essa zombeteira passagem evidencia a atualidade dessa questão urbanística, no início do século XX, acentuadamente marcada pelos modelos europeus de urbanização.

Repercute no Diário os fatos políticos e sociais engendrados pelo regime republicano no âmbito de um país que começava a despontar como nação, marcado essencialmente pela influência europeia.

Vemos, portanto, que esse desdobramento em nível mundial da cultura europeia forçava no sentido de uma europeização das consciências e gozava da vantagem de ser o único padrão de pensamento compatível com a nova ordem econômica unificada, fornecendo, pois, o subsídio para as iniciativas de modernização das sociedades tradicionais. $O$ caso brasileiro é típico (SEVCENKO, 2003, p. 102).

Atento a esses movimentos, Lima registrou seus sentimentos e impressões não apenas nas notas íntimas, mas também em sua produção ficcional e jornalística, conforme assinalou Broca:

Começaria a acentuar-se um certo antagonismo entre a "cidade", os bairros aristocráticos, de gente fina, dos super civilizados, e o subúrbio com sua pequena burguesia, de costumes simples - antagonismo de que a obra de Lima 
Barreto constituiria uma admirável ilustração (BROCA, 2005, p. 38).

É preciso lembrar que Lima morava no subúrbio, a partir de 1902 sua família passou a residir no Engenho Novo. E, no ano seguinte, mudou-se para Todos os Santos; bairros modestos situados na zona norte do Rio de Janeiro. Esse fato o obrigava indispensavelmente a transitar diversas vezes entre a região central da cidade e o subúrbio, já que trabalhava na Secretaria de Guerra, situada no centro, além de frequentar alguns cafés, ambiente no qual travou conhecimento com intelectuais da época.

Lima Barreto andara a princípio pelo Café Jeremias ou na Americana, onde se via cercado por uma roda de "rapazes instruídos", havendo determinação expressa de não se conversar jamais literatura, o que devia produzir reação contra o clima artificialmente literário dessas rodas boêmias. Depois, veio a tornar-se assíduo no Café Papagaio, num grupo determinado Esplendor dos Amanuenses, que se reunia todas as tardes para discutir "coisas graves e insolúveis", do qual faziam parte Bastos Tigre, Domingos Ribeiro Filho, Rafael Pinheiro, Amorim Júnior, Calixto, João Rangel e o caricaturista Carlos Lenoir, o Gil da revista mundana A Avenida (Ibid., p. 73).

Além dos cafés, as livrarias eram ponto de encontro dos escritores.

Destacamos a Garnier, situada à Rua do Ouvidor, fundada em 1844, pelo francês Louis Baptiste Garnier. Essa importante livraria, cujas atividades estenderam-se por quase um século, era frequentada assiduamente por Machado de Assis (1839-1908), que teve aí suas obras publicadas, bem como por outros literatos, a exemplo de José Veríssimo (1857-1916).

Outro ambiente em que Lima comparecia com certa regularidade era a Biblioteca Nacional, espaço para muitas de suas leituras. Teria começado a frequentar essa biblioteca em 1897 (BARRETO, 2001, p. 18), aos dezesseis anos, portanto. 
Não se pode deixar de assinalar a presença de Lima Barreto nas redações dos jornais, onde atuou até o fim de sua vida. Em 1902, iniciou sua colaboração em jornais acadêmicos, escrevendo para $A$ Lanterna, a convite de Bastos Tigre (1882-1957) ${ }^{35}$, com quem editou um periódico de curta duração: $A$ Quinzena Alegre. A partir daí, sua atuação jornalística intensificou-se, com colaborações em diversos jornais cariocas, dentre os quais se destacaram: Correio da Manhã, A Gazeta da Tarde e Correio da Noite.

Permanecia, portanto, a maior parte do tempo, borbotando suas ideias nesses ambientes que ocupavam o centro da vida intelectual - os cafés, a biblioteca, as redações dos jornais. Espaços de onde emanavam saber, ciência, ilustração. Por essa razão, para Lima, nos diz Barbosa (op. cit., p. 159), "era sempre um tormento voltar a casa, sentir de perto a triste realidade que era a sua vida", visto sua esfera privada ser tão dessemelhante da arena pública onde Ihe era afeito atuar. Procurava "sempre entrar em casa ao anoitecer, quando todos estavam recolhidos" (BARRETO, 2010a, p. 61). Era hábito seu, quando estava em casa, manter-se recolhido em seu quarto, espaço onde guardava livros e se refugiava para ler e escrever. Passemos então a espreitar seu repertório teórico e literário.

${ }^{35}$ Era amigo de Lima Barreto. Diplomou-se pela Escola Politécnica em 1906. Além de engenheiro, atuou ainda como jornalista, publicitário e bibliotecário. 


\subsection{As Leituras de Lima Barreto}

Um rápido olhar sobre o Diário Íntimo traz a tona a substancial erudição de Lima Barreto, visto que nos deparamos logo nas primeiras páginas com referências ao positivismo e nomes como o de Aristóteles, Taine, Balzac, José de Alencar. Com efeito, desfilam, pelas páginas íntimas, célebres figuras das mais diversas nacionalidades, dos franceses aos russos, cujas obras e teorias foram objetos de reflexões de Lima.

Diante dessa constatação, realizamos um preciso levantamento compreendendo os nomes desses autores citados, agrupados segundo ofício pintor, filósofo, escritor, crítico, pesquisador, historiador - e de acordo com o país de origem. Obtivemos o total de 41 personalidades francesas, 17 brasileiras, 8 portuguesas, 7 alemãs, 6 inglesas, 2 russas, além de 1 da Itália, Espanha, Ucrânia e Polônia; referências citadas e, muitas vezes, comentadas por Lima. Não é tarefa fácil demonstrar aqui o domínio intelectual desse escritor carioca, dado o expressivo número de autores que compunham seu repertório. Tentaremos, pois, brevemente, apresentar as figuras mais representativas pela importância do legado de suas obras.

Dentre os autores anotados no Diário, destacaram-se os franceses Honoré de Balzac, Gustave Flaubert, Hippolyte Adolphe Taine, Jules Gaultier; no que concerniram aos brasileiros, temos Olavo Bilac, Castro Alves, Raul Pompéia, José Veríssimo. Da nossa matriz mais imediata, Portugal, fizeram parte do repertório de leituras de Lima os autores Luís Vaz de Camões, Camilo Castelo Branco, Eça de Queiroz. Dentre os alemães, figuraram Arthur Schopenhauer, Friedrich Nietzsche e Ernst Haeckel. Os russos Fiódor 
Dostoiévski e Alexandra Kollontai também foram lidos por Lima; do mesmo modo que os ingleses Charles Darwin, Willian Shakespeare, Thomas Carlyle, Herbert Spencer e Jeremy Bentham.

A leitura das obras desses escritores e de tantos outros presentes nas páginas íntimas ocupou a pena limabarretiana, registro que vem comprovar que o autor compartilhou do conhecimento dos homens letrados de seu tempo. Seria banal destacar aqui tais referências de leitura se tratássemos de um autor, cujas condições tanto sociais, quanto materiais Ihe fossem favoráveis para o contato e aquisição de tais obras, contudo, é notável elucidar que, no caso de Lima, modesto funcionário público residente do subúrbio, provido de parcos recursos, estudar esses autores acima mencionados, escapa do habitual, dado seu perfil sócio-econômico.

Com o intuito de conhecermos mais a fundo os modelos de Lima, faz-se oportuno apresentar aqui a "Coleção Limana"36, modo como nomeou sua pequena biblioteca pessoal, inventariada por ele mesmo em 1917. A meticulosa descrição desse inventário, onde constou o número das estantes e das prateleiras nas quais se situavam seus livros, revela a preocupação do autor em manter esse material bem organizado. Em cinco estantes desiguais, já que a primeira e a quarta possuíam cinco prateleiras, a segunda quatro e a terceira três prateleiras, os livros foram ordenados numericamente por título e autor, não obedecendo a uma sequência temática definida. Havendo ainda material distribuído em cima das estantes e das mesas. Além de livros (encadernados e brochados), figuravam diversas revistas brasileiras e

\footnotetext{
${ }^{36}$ O inventário da "Coleção Limana" encontra-se disponível em Barbosa (op.cit., p. 375-402), assim como ao final da primeira edição do Diário Íntimo (1953). O manuscrito do inventário acha-se na Divisão de Manuscritos da Biblioteca Nacional do Rio de Janeiro.
} 
estrangeiras, dicionários, jornais, mapas, assim como as obras do próprio autor separadas em seção chamada "Manuscritos e Originais".

A temática da "Coleção Limana" caracteriza-se pela diversidade, contendo livros do âmbito das ciências humanas (literatura, história, sociologia, filosofia, antropologia) às ciências biológicas (biologia, química) e exatas (cálculo, mecânica, geometria), o que evidencia o largo campo de conhecimento pelo qual Lima nutria interesse. Tal variedade sintetiza ainda a sólida substância de sua matéria intelectual. Lembremos de seus estudos de engenharia civil, carreira renunciada em virtude da necessidade de sustentar a família, fato que não lhe cerceou o espírito curioso.

No que tange propriamente aos livros, verificamos haver o total de $651^{37}$ volumes, sendo que mais de sessenta por cento dessa soma, trata-se de obras de autores franceses ou traduções francesas de outros escritores estrangeiros. Esse levantamento nos possibilitou observar uma vez mais a predominância de marcas francesas no universo limabarretiano. Por essa razão, julgamos relevante visualizar quais autores e livros franceses referidos em Diário Íntimo encontravam-se nas estantes de Lima. O resultado desse levantamento confirmou que grande parte dos títulos franceses presentes no Diário compunha a biblioteca pessoal do autor. Sublinhamos onze obras de Balzac, seis de Taine, quatro de Anatole France, a Pléiade de Gobineau, dentre

${ }^{37}$ Abaixo, resultado do levantamento efetuado com base na "Coleção Limana". Não foram contabilizadas revistas, dicionários, jornais, assim como as obras de Lima Barreto que constam em sua biblioteca.

Quantidade de Livros constantes em "Coleção Limana" distribuídos por origem dos autores.

\begin{tabular}{|l|l|l|l|l|l|l|l|}
\hline & Franceses & Brasileiros & Italianos & Espanhóis & Portugueses & Ingleses & Total \\
\hline № de Livros & 423 & 183 & 18 & 10 & 10 & 7 & \\
\hline Porcentagem & $64 \%$ & $28 \%$ & $3 \%$ & $2 \%$ & $2 \%$ & $1 \%$ & \\
\hline
\end{tabular}


inúmeras outras obras de autores igualmente notáveis ${ }^{38}$.

A preponderante presença da França tanto nas páginas íntimas quanto na "Coleção Limana" instigou-nos a refletir a respeito do diálogo estabelecido com essa tradição de matriz europeia. Buscaremos, pois, compreender como se construiu a postura de Lima enquanto brasileiro olhando para o legado francês, atentando para os modelos dos quais ele se apropriou ou rechaçou, referências de grande valor que contribuíram para sua posição autoral.

Cabe, nessa discussão, uma nota de ordem metodológica. Ressaltamos que a literatura comparada, área na qual esse projeto de pesquisa inscreve-se, indispensavelmente ocupa-se desse trânsito de influências, visto que seu material de análise estende-se além das fronteiras de um único país à medida que compara com e no contexto de mais de uma literatura, bem como busca estudar as intersecções significativas não apenas entre obras literárias, mas também entre diferentes linguagens (como literatura e cinema, por exemplo) e diferentes disciplinas. Nessa perspectiva, conforme advertiu Remak é preciso investigar "o que foi mantido e o que foi rejeitado, e por quê, e como o material foi absorvido e integrado, e com que sucesso?" (COUTINHO; CARVALHAL, 1994, p. 176); essas questões nortearão nossas hipóteses interpretativas ao longo desse estudo.

${ }^{38}$ Algumas obras dos autores acima referidos presentes na biblioteca de Lima Barreto - De Balzac: Le Père Goriot, La Peau de Chagrin, La Cousine Bette, Eugénie Grandet, Louis Lambert. De Anatole France: Le Lys Rouge, L'Église et la République, Pierre Nozière. De Taine: Essais, Origines de la France Contemporaine. 


\subsection{Marcas Francesas no Diário Íntimo}

O universo francês, conforme já apontamos, impõe-se de maneira expressiva aos olhos do leitor do Diário Íntimo. Nossa pesquisa contemplou todas as referências relacionadas à França: autores, obras, revistas, jornais, lugares, palavras. Todas essas categorias foram organizadas em tabelas quantitativas, as quais nos permitiram entrever a estreita relação de Lima com esse país europeu. Vale lembrar que esse não era um aspecto observável apenas em Lima Barreto, segundo confirma Amaral (1996, p. 30), a França "impregnava o ar cotidiano dos literatos brasileiros do século passado: todos falavam francês, liam francês, tomavam a França como modelo literário e existencial". Digno de nota ainda foi a enorme quantidade de produtos franceses que chegaram ao Brasil, além de livros de escritores franceses e de traduções francesas que eram avidamente consumidos ${ }^{39}$.

Em 1900, a elite já incorporara ao cotidiano o uso do francês e a familiaridade com a cultura francesa. Muitas mulheres da elite liam a literatura francesa; muitos homens da elite também o faziam. Na verdade, vários literatos escreviam e alguns até pensavam naquela língua. Quando liam obras de autores ingleses e alemães, os brasileiros em geral o faziam em traduções francesas (NEEDELL, op. cit., p. 230).

Com efeito, é inegável o fascínio que a cultura francesa exerceu em nossa elite.

\footnotetext{
${ }^{39}$ Nesse cenário, não podemos ignorar as relações comerciais mantidas entre Brasil e Inglaterra, país que, aliás, levava vantagem tributária se comparado à França, visto os produtos ingleses estarem submetidos à taxa aduaneira de 15\%, enquanto a taxa dos artigos franceses serem da ordem de $24 \%$. Essa situação perdurou até 1826, quando se estabeleceu um tratado de amizade, navegação e comércio entre Brasil e França, a partir daí a taxa incidida sobre os artigos franceses passou a ser também de 15\%. Cf. HOLANDA, 2004b, p. 182-183.
} 
A Rua do Ouvidor, no Rio de Janeiro, com suas lojas bem sortidas de gêneros franceses, seria comparada, por mais de um visitante, na Rua Vivienne, de Paris. $E$ as habitações e a própria alimentação tornava-se mais requintada (HOLANDA, 2004b, p. 181-182).

Remontemos, num golpe de vista, às origens do gosto brasileiro pela tradição francesa através da precisa síntese de Needell:

Isto aconteceu de modo bem irônico. O príncipe regente, dom João $\mathrm{VI}$, forçado pelos exércitos franceses a transferir a Corte de Portugal para o Brasil (1807), mais tarde procuraria embelezar seu reino tropical recorrendo às artes francesas, na sequência de Waterloo. Quando as relações amigáveis entre o Império português e a França foram restauradas, dom João VI decidiu recrutar artistas e artesãos franceses, em seu esforço para fortalecer a Monarquia no Brasil por meio da promoção das artes e ciências no âmbito das instituições reais (NEEDELL, op. cit., p. 175).

Sendo assim, as leituras francesas ou em francês anotadas por Lima, assinalam que o autor participava ativamente do contexto literário em que se inscreveu, indicando não só a sua atuação como homem de letras que era, mas também apontam o intelectual Lima Barreto atento à maciça presença francesa há muito aclimatada em nosso país onde "conhecer a literatura, sobretudo a francesa, era a marca de um indivíduo bem educado" (Ibid., p. 211). Embora a trajetória de Lima não correspondesse ao perfil típico originário da maior parte dos literatos à época - ricos, vinculados a setores médios urbanos ou filhos de fazendeiros instruídos -, ele recebera boa instrução formal $^{40}$, pois estudara em instituições de prestígio, compartilhando de viés do

\footnotetext{
${ }^{40}$ Aos oito anos de idade, começou a frequentar a escola pública dirigida por D. Teresa Pimentel do Amaral. Em 1891, passou a cursar o Liceu Popular Niteroiense, após seu padrinho, o visconde de Ouro Preto, concordar em custear sua educação. Lá ficara até 1894, completando o curso secundário e parte do suplementar. Em 1896, matriculou-se no Colégio Paula Freitas, também como aluno interno, no curso anexo de preparatórios para a Escola Politécnica, onde ingressara no ano seguinte.
} 
saber letrado.

O resultado dos levantamentos efetuados no Diário Íntimo nos forneceu dados concretos. Obtivemos o total de 41 autores, 32 palavras, 19 obras, 3 revistas, essa mesma quantidade de lugares franceses referidos, 1 jornal, além de 4 trechos de obras de autores estrangeiros citados em francês, sendo que tais trechos são de autoria de 2 alemães - Nietzsche (1844-1900) e Helmholtz (1821-1894).

Diante de todos esses dados, escolhemos nos concentrar nas citações relativas ao universo literário e/ou social francês. Esse recorte nos deu o total de 35 excertos de obras francesas citados de maneira bastante diversa. Tendo em vista esse aspecto, buscamos elaborar categorias que pudessem agrupar a partir de traços formais comuns tais citações. Foi então que criamos tipologias das citações francesas para classificar as referências literárias e/ou sociais presentes no Diário. Assim, agrupamos tais excertos conforme as seguintes tipologias: trecho, título e autor; trecho e título; trecho e autor; autor e título; somente título e, por fim, somente autor. Todas essas tipologias foram igualmente distribuídas em tabelas que nos permitiram quantificá-las.

Visualizamos que a maior parte desses trechos foi marcada por Lima segundo a tipologia autor mais título (11), seguidos por somente autor (9) e por trecho, título e autor (8). As demais citações classificam-se de acordo com as tipologias trecho e autor (4), somente título (2) e trecho e título (1). A etapa seguinte foi descobrir a referência completa dos trechos que foram identificados por somente autor ou somente pelo título da obra.

Após termos realizado essa classificação quantitativa, passamos a observar em quais contextos cada citação se situava, atentando para os 
comentários tecidos a respeito de cada trecho de obra anotada. Aqui, é válido ressaltar que muitos dos excertos encontram-se somente citados, ou seja, Lima não se debruçou mais detidamente sobre o teor da citação, já que não registrou nenhum tipo de comentário. Desse modo, tornou-se difícil, à luz somente das citações, compreender o sentido de tais trechos, especialmente quando se trata de excertos de obras literárias, destacados de seu contexto original. Explicitaremos a seguir, com alguns trechos retirados do Diário, os casos em que Lima anotou a citação sem comentá-la. É possível também, a partir desses exemplos, observar as tipologias por nós categorizadas:

«No esforço voluntário, a reflexão interior se apercebe de um "eu" que quer e de um 'não-eu' que resiste. » Maine de $\operatorname{Biran}^{41}$ (DI, p. 35 - Sem data, 1903).

"La muse, si revêche qu'elle soit, donne moins de chagrins que la femme. Je ne peux accorder l'une avec l'autre. " Flaubert a George Sand (DI, p. 57 - Sem data, 1904).

Rouché. L'Art Théatrale Moderne (DI, p. 147 - Sem data, 1910).

«Le danger de l'éducation littérarie est d'inspirer un désir immodéré de la gloire sans donner toujours le sérieux moral qui fixe le sens de la vraie gloire. "E. Renan, L'Antéchrist, 315 (DI, p. 161 - Sem data, 1911).

"Un écrivain ne doit songer, quand il écrit, ni à ses maîtres, ni même à son style. S'il voit, s'il sent, il dira quelque chose; cela sera intéressant ou non, beau ou médiocre, chance à courir. "Remy de Gourmont. Le probleme du Style. p. 31 (DI, p. 189 - Sem data, 1917).

«Loué par ceux-ci, blâmé par ceux-là, me moquant des sots, bravant les méchants, je me hâte de rire de tout, de peur d'être obligé d'en pleurer. » Figaro, Beaumarchais (DI, p. 190 - Sem data, 1917).

«Aucun âge n'a le droit d'imposer sa beauté aux âges qui

\footnotetext{
${ }^{41}$ No caso desses excertos é necessário esclarecer que as aspas ( ") dizem respeito às aspas colocadas por Lima. Respeitamos a ortografia do Diário.
} 
précèdent; aucun âge n'a le devoir d'emprunter sa beauté aux âges qui précèdent. II ne faut ni dénigrer ni imiter, mais inventer et comprendre.» Taine, Essais, página 255 (DI, p. $198-21$ de janeiro de 1918).

Ch. Labitte - Divine Comédie avant Dante. Aroux: " Dante hérétique, revolutionnaire et socialiste. » (DI, p. 215 - Sem data, 1921).

Faz-se oportuno aqui refletirmos, de modo breve, acerca da função e usos da citação no âmbito das páginas íntimas. Ora, as citações, de um modo geral, são feitas seja para apoiar uma hipótese, seja para sustentar uma ideia ou ilustrar um raciocínio. Tem como intenção oferecer o respaldo necessário para que se possa comprovar a veracidade dos argumentos defendidos e possibilitar o aprofundamento da análise proposta. Demonstra, assim, familiaridade com determinado campo de conhecimento. No caso de citações anotadas no diário de um escritor, pode significar ainda material recolhido para futura elaboração ficcional à medida que os excertos compilados podem servir como substrato de ideias. Tratando-se de um diário, os excertos selecionados podem ainda ligar-se de algum modo com episódios da vida daquele que escreve, com a articulação de seu pensamento.

Diante desses trechos acima relacionados, é coerente pensarmos que se tratam daquilo que mais chamou a atenção de Lima no momento da leitura dessas obras. Dizem respeito às passagens por ele eleitas e transferidas para suas notas íntimas, portanto, sinalizam, ainda que discretamente, para o caminho por onde transitava a curiosidade e o interesse limabarretiano. Como vemos, em algumas das citações, Lima indicou a página de onde retirou 0 excerto, fato que pode assinalar o desejo de retornar à obra sem perder de vista o trecho destacado. No corpo do Diário, parece que "[o] fragmento 
escolhido converte-se ele mesmo em texto, não mais fragmento de texto, membro de frase ou de discurso, mas trecho escolhido, membro amputado [...]" (COMPAGNON, 1996, p. 13) costurado às reflexões de Lima, que recorta e reserva petrechos literários munindo-se deles. Considerados esses excertos, desse modo, ora relacionam-se mais com a face íntima do indivíduo Lima Barreto, como o trecho supracitado de Beaumarchais (1732-1799); ora com a face pública do escritor, a exemplo das citações de Gourmont (1858-1915) e Taine (1828-1893). Em 1917, quando Lima citou Beaumarchais, lembremos que já havia lançado os romances Recordações do escrivão Isaías Caminha (1909) e Triste fim de Policarpo Quaresma (1916), os quais não fizeram muito sucesso, faz sentido então entrevermos nas palavras de Beaumarchais uma expansão do eu confessional, que poderia ser entendida do seguinte modo: "Elogiado por uns, censurados por outros, zombando dos idiotas, desafiando os maus, apresso-me a rir de tudo com medo de ser obrigado a chorar". O trecho de Gourmont, por sua vez, soa como um direcionamento aos escritores, cujo ofício é arriscado. Já a citação de Taine assemelha versar acerca de traços próprios a cada período da história, que deveriam ser considerados dentro do contexto em que se situam, critério útil, por exemplo, ao jornalista. Observados por essa perspectiva, Lima dá mostras de aderir ao pensamento desses teóricos.

Ressaltamos que muitos dos títulos citados no Diário encontravam-se em sua biblioteca pessoal, conforme verificamos no inventário da "Coleção Limana", já referido. Tais referências compuseram o cabedal teórico consultado pelo autor identificando, desse modo, os modelos que the serviram para o desenvolvimento de seu trabalho intelectual. Não podemos desprezar ainda as 
implicações de ordem psicológicas, sociológicas, políticas e históricas que permeiam $\mathrm{o}$ ato de citar. Em alguma medida, a escolha efetuada é reveladora de adesão a paradigmas vigentes. Nesse sentido, a recorrência de referências francesas indica o prestígio gozado pela literatura francesa se comparada à produção literária dos demais países no contexto brasileiro. Conforme nossos levantamentos comprovaram, é coerente frisar a expressividade dos modelos teóricos e literários franceses, caudalosa fonte para Lima Barreto.

\subsection{Referências Literárias Francesas comentadas no Diário Íntimo}

Embora haja muitas citações literárias lançadas no Diário aparentemente sem contexto, há outras comentadas de forma perspicaz. Os comentários, fruto das reflexões de Lima, sinalizam mais expressamente sua postura em relação a temas diversos pertinentes ao seu tempo. Vejamos uma delas:

«Toute idée fausse est dangereuse. On croit que les rêveurs
ne font point de mal, on se trompe, ils en font beaucoup. Les
utopies les plus inoffensives en apparence exercent
réellement une action nuisible. Elles tendent à inspirer le
dégoût de la réalité ». Anatole France, Le Lys Rouge.
Podemos muito bem explicar assim a constante irritabilidade
dos neófitos e adeptos de utopias e reformas sociais. Vede
Barbosa Lima, a quem eu creio sincero, entre nós, pois que
todas as reformas da atualidade, no nosso meio, se vão
polarizando no positivismo religioso (DI, p. 43 - Sem data,
1904).

Interessa-nos aqui observar de que modo Lima apreendeu a matéria lida. Nesse excerto supracitado, serviu-se de um trecho de O Lírio Vermelho [Le Lys Rouge], obra lançada em 1894 por Anatole France (1844-1924), autor francês que figura como um de seus autores preferidos, para refletir acerca do 
contexto político brasileiro. Nessa nota, a alusão ao positivismo, importante corrente filosófica de origem francesa tão em moda nos idos do século XIX, não poderia passar despercebida.

No Brasil, a doutrina de Augusto Comte (1798-1857), filósofo francês criador do Positivismo, encontrou ambiente favorável para exercer influência filosófica, científica, política e religiosa. Tem-se notícia de que o Positivismo por aqui chegou por meio da biologia com a tese Plano e Método de um Curso de Fisiologia, sustentada, em 1844, pelo baiano Justiniano da Silva Gomes com vistas à catedra de Fisiologia da Faculdade de Medicina da Bahia. Tese na qual se encontram referências explícitas a Augusto Comte. A essa, outras teses se seguiram inspiradas na filosofia comteana, uma vez que tal filosofia

[d]esde 1850 infiltra-se nos principais estabelecimentos de ensino no Brasil, Escola Militar do Rio, Escola de Marinha, Colégio Pedro II, Escola de Medicina e Escola Politécnica, o pensamento de Augusto Comte difundido pelo Curso de filosofia Positiva (SOARES, 1998, p. 146-147).

Com efeito, larga foi a influência positivista nos mais diversos círculos.

Em 1876, foi fundada a primeira sociedade positivista brasileira, estando à frente Teixeira Mendes (1855-1927), Miguel Lemos (1854-1917) e Benjamim Constant (1836-1891 $)^{42}$. Nesse mesmo ano, Miguel Lemos, após viagem a Paris, fundou a Sociedade Positiva do Rio de Janeiro. Cidade onde, no ano seguinte, se deu a construção de um templo positivista, erigido segundo as recomendações de Comte, único no mundo. Somadas todas essas ações,

\footnotetext{
${ }^{42}$ Três importantes figuras ao longo dos primeiros anos republicanos. Baseados nos princípios positivistas atuaram politicamente orientando os novos rumos nacionais. Teixeira Mendes foi o criador de nossa bandeira. Miguel Lemos dirigiu a Igreja Positivista do Brasil. Benjamin Constant foi um dos principais articuladores da campanha republicana.
} 
verificamos o alcance do pensamento comteano em nosso país.

Ao Positivismo ficamos devendo algumas importantes conquistas sociais: grande influência no movimento abolicionista, na consolidação do federalismo presidencialista de nossos primórdios, na instituição dos feriados nacionais, na concepção de nossa bandeira, onde figura legenda positivista "ordem e progresso" e na separação da Igreja e do Estado (lbid., p. 152).

Lima Barreto, por seu turno, fora também contagiado pelo "sarampo positivista", para usarmos o modo como Barbosa (op. cit.) caracteriza a recepção dessa corrente francesa no Brasil: "[n]essa idade [pelos 15 anos], porém, não tinha a mínima preocupação literária; havia até abandonado o [s]eu Júlio Verne e todo [ele] era seduzido para o positivismo e cousas correlatas" (BARRETO, 1956b, p. 97). Ilustra, pois, esse contágio as palavras de Lima acima mencionadas que torna vivo o fundo positivista no horizonte nacional.

Além do positivismo, aportou ainda da França o bovarismo. São dignas de nota as "impressões de leitura" de Lima acerca da obra O Bovarismo [Le Bovarysme], de Jules Gaultier (conceito aludido no primeiro capítulo) que demonstram o estreito contato desse autor com o referencial teórico de origem francesa. Acompanhemos seu ponto de vista sobre essa obra:

O bovarismo de Jules Gaultier. Impressões de Leitura.

O bovarismo, diz seu autor, é um livro que não visa instituir nenhuma reforma, se aplica a matéria que os homens, mais que nenhuma outra espécie, acreditam marcar, eles mesmos, uma forma; trata da evolução na humanidade, isto é, dos modos de mudança nesta parte do espetáculo fenomenal em que o fato da consciência parece atribuir ao ser que sofre a modificação, com o poder de dar causa, o dever de dirigir. Sob essa ilusão, a vontade humana acredita intervir no turbilhão de causas e efeitos que a envolvem. A constatação, verificação do fato, tende na linguagem a se formular em regra moral, porque a ilusão do fato, engendrada pelo reflexo da atividade na 
consciência, é tão forte que domina as formas da linguagem. O bovarismo, livro, é um aparelho de óptica mental. É do prefácio. O bovarismo é o poder partilhado no homem de se conceber outro que não é. Precisar o papel do bovarismo como causa e meio essencial da evolução na humanidade $(D I$, p. 93 -28 de janeiro de 1905).

Observamos a tentativa de Lima em definir o que seria bovarismo mesclada a uma espécie de análise desse conceito, buscando compreendê-lo a partir de uma perspectiva mais ampla - suas manifestações na humanidade. Ao perseguir essa investigação dá continuidade a sua análise apontando duas vertentes para tratar da "pessoa humana" (DI, p. 94 - 28 de janeiro de 1905):

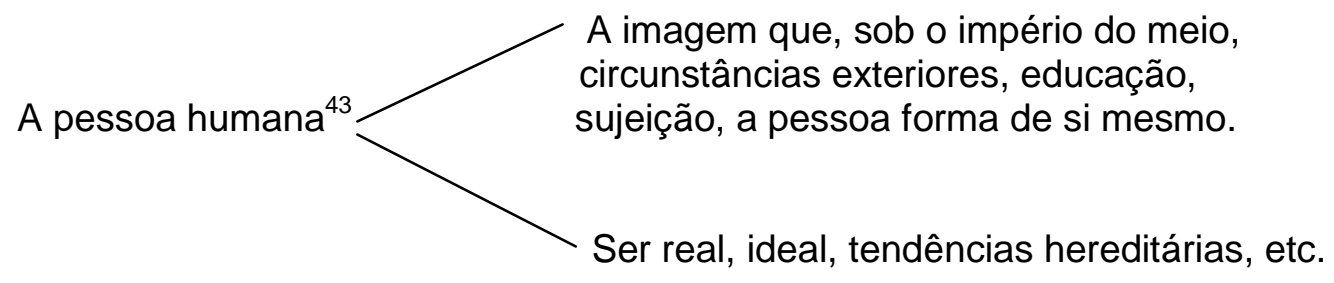

Nessa formulação, duas ideias são fundamentais no âmbito do século XIX, são elas: "meio" e "tendências hereditárias". Esse pensamento corolário de um modelo evolucionista, amplamente difundido, consoante o qual a ação do meio e a mistura das raças eram fatores essenciais para a formação de um povo, encontrou-se presente na linha de raciocínio de Lima Barreto, que não escapou das teorias deterministas de seu tempo. Acerca desses aspectos, nos deteremos com mais vagar no próximo capítulo quando analisaremos as referências marcadamente de cunho social. Por ora, é pertinente frisar a aproximação proposta por Lima entre literatura e ciência que, ao partir de um conceito originário da obra Madame Bovary, articulou um pensamento sobre a evolução da humanidade perpassando o saber científico em voga à época.

\footnotetext{
${ }^{43}$ Reproduzimos o modo como Lima Barreto cita esse excerto, conforme aparece no Diário.
} 
Acrescentem-se, nesse bojo das referências literárias, algumas anotações de Lima sobre o que poderíamos chamar de indicações bibliográficas, conforme podemos conferir:

Sobre a literatura em geral, ler Brunetière, Revue des Deux Mondes - Janeiro e Fevereiro de 1892.

Nietzsche: Revue des Deux Mondes - Setembro a Outubro de 1892.

Pascal: Revue des Deux Mondes - 15 de agosto 1879, Brunetière (DI, p. 146 - Sem data, 1910).

O recorrente destaque dado à Revue des Deux Mondes ${ }^{44}$ desperta a atenção para essa referência francesa. Fundada em 1829, essa revista foi, sobretudo no século XIX, espaço privilegiado de importantes discussões literárias. Célebres escritores contribuíram com suas reflexões para o renome da revista, de George Sand a Chateaubriand, de Sainte-Beuve a Dumas, Musset, Renan, Gaultier, entre tantos outros. Tornou-se, portanto, uma referência essencial para os que desejavam manterem-se antenados acerca da vida intelectual francesa e europeia de um modo geral. Lima foi assíduo leitor dessa revista que apareceu repetidas vezes no inventário da "Coleção Limana"; na primeira prateleira da terceira estante: "Revue des Deux Mondes (12 vols.; 1851)"; na terceira prateleira da quarta estante: "Um lote da Revue des Deux Mondes, de 1877"; em cima das estantes e das mesas: "Um caderno com artigos da Revue des Deux Mondes" e "Artigos da Revue des Deux Mondes, 3 cadernos".

As considerações feitas até aqui bastariam para conferirmos papel relevante a essa revista na formação intelectual de Lima Barreto. Porém, há

${ }^{44}$ Essa revista existe até os dias de hoje, consta no arquivo de seu site todos os artigos publicados desde 1829 até 2011, podendo ser localizados por autor, título ou ano. Cf. http://www.revuedesdeuxmondes.fr/user/search.php. 
ainda outra notícia biográfica incontornável, segundo Barbosa (op. cit., p. 358), Lima morrera abraçado a um volume da Revue des Deux Mondes, fato que nos permite concluir ter sido esta a última leitura do autor.

Cumpre-se ainda ressaltar a intenção de Lima de elaborar um curso de filosofia "segundo artigos da Grande Encyclopédie Française du Siècle XIXème" (DI, p. 35 - Sem data, 1903). Com esse curso, esquematizado em oito partes, Lima tinha o propósito de percorrer a "história do pensamento filosófico", passando pelos gregos aos hindus, concentrando-se também na "Filosofia contemporânea. Sociologia. Estudo das raças", constante temática de seu interesse. Verificamos, no primeiro item da primeira parte do programa, um longo trecho citado em português extraído da Grande Encyclopédie:

I - A filosofia tem por fim explicar até nos seus últimos fundamentos a existência do mundo, devendo formar um conjunto de nossos conhecimentos particulares a convergir para uma concepção do mundo, do homem e da vida, que satisfaça às necessidades do entendimento e às exigências do espírito humano. Deve ser uma espécie de ciência geral, destinada a constituir, isenta de contradições, um edifício construído com os conhecimentos gerais desvendados pelas ciências particulares. O seu fim é, portanto, organizar um conhecimento, uma disciplina em métodos seus, teorias organizadas e um plano geral, sendo, pois, arbitrário classificar de filosóficos os modos de atividade intelectual que consistem em pontos de vista espontâneos, em reflexões sem técnica e sem método, em representações místicas e em crenças. Essas organizações, essa espécie de atividade mental, só pode entrar na verdadeira filosofia como dados, como meros auxiliares, talvez mesmo como fatos, a examinar à luz do critério filosófico. A filosofia é essencialmente uma teoria intelectual organizada. (Artigo Filosofia, da Grande Encyclopédie) (DI, p. 36-37 - Sem data, 1903).

Vemos nessa passagem Lima iniciar seus estudos buscando uma espécie de definição do que seria filosofia, preocupado, portanto, com um rigor metodológico. Como é perceptível, recorreu às fontes francesas, alicerce de 
seu projeto de estudos. A opção pela Grande Encyclopédie não foi gratuita, visto a importância dessa fonte que se propôs a divulgar a ciência moderna, inventariando as descobertas e teorias das mais diversas áreas do conhecimento - novidades da astronomia, da física, da química, assim como da história, antropologia e das ciências naturais. Em suma, todo saber moderno ocupou as páginas dessa copiosa obra, desse frutífero século repleto de significativas invenções e descobertas que foi o século XIX.

Decorreram, no segundo item do programa limabarretiano, considerações acerca da ciência sem perder de vista a filosofia, baseadas num artigo de Victor Delbos (1862-1916). Lima pareceu fazer, nesse caso, um tipo de citação indireta dessa fonte de consulta, conforme indicou ao final da consistente explanação: "[é] mais ou menos o artigo de Victor Delbos" (DI, p. 38 - Sem data, 1903). Filósofo e historiador francês, professor da Sorbonne, Delbos, cujos estudos tornaram-se uma referência fundamental no domínio da filosofia, ficou conhecido pela sua tese de doutoramento (1902) sobre a formação da filosofia de Kant.

Eis aí as bases do "curso de filosofia por Afonso Henriques de Lima Barreto para Afonso Henriques de Lima Barreto" (DI, p. 35 - Sem data, 1903), assim enunciado.

A atenção de Lima esteve verdadeiramente voltada para as referências de origem francesa, pois mesmo quando relatou situações miúdas do cotidiano, não desapercebeu tais marcas. Revelador dessa observação é o momento em que falou de Dona Guilhermina Rocha, famosa atriz carioca dos idos de 1900; ao recordar-se dos livros vistos na casa desta, assinalou: "[f]alei-Ihe. Ela me disse que me conhecia. De fato, ela morava na Rua das Marrecas e, por cima 
da sua casa, no sótão, o Nicolau Ciâncio. Fui lá muitas vezes e a vi com volumes de Racine, Marivaux, Beaumarchais." (DI, p. 160 - 05 de maio de 1911, grifos nossos). Sublinhamos aqui os nomes de três dramaturgos fundamentais para o desenvolvimento do teatro francês, seguramente conhecidos por Lima. Não sabemos quais outros títulos se encontravam nas estantes dessa senhora, porém, não podemos desprezar a referência a esses franceses por Lima notados.

À vista desse vasto repertório do universo literário francês aqui apresentado, que evidencia o extenso conhecimento de Lima, verificamos o intenso contato mantido com os modelos franceses, já que estabeleceu relação crítica com as obras lidas. Tal proximidade aponta a forte identificação de caráter social e cultural do autor com a França. Com efeito, o referencial francês aparenta ter sido uma espécie de fertilizador das ideias limabarretianas. Tais leituras Ihe valeram permanecer atualizado com as discussões promovidas no contexto brasileiro, permitindo efetiva participação no cenário intelectual. Visto por essa perspectiva, não seria despropositado pensar na função desses modelos europeus, portanto hegemônicos, adotados como forma de angariar apoio a fim de alcançar seu objetivo de ser notavelmente reconhecido pelo métier de literato. Fazer parte do círculo literário canônico compreendia voltar-se para a França, tradição ensejada no início do século XIX com a chegada da Missão Artística Francesa $(1816)^{45}$.

A postura autoral de Lima Barreto, contudo, demonstra estarmos diante

\footnotetext{
45 Em 26 de março de 1816 aportou no Rio de Janeiro um grupo de artistas franceses, liderados por Joachim Lebreton (1760-1819), secretário recém destituído do Institut de France, acompanhado do pintor Debret (1768-1848), do paisagista Nicolas Taunay (1755-1830) e de seu irmão, o escultor Auguste Marie Taunay (1768-1824), do arquiteto Grandjean de Montigny (1776-1850) e do gravador de medalhas Charles-Simon Pradier (1783-1847). O objetivo dessa missão era fundar a primeira Academia de Arte no Reino Unido de Portugal, Brasil e Algarves.
} 
de uma consciência cindida, visto não aderir à elite afrancesada, pela qual não é aceito, mas também não se identifica completamente com a classe social a qual está atrelado pela diminuta condição financeira. Parece-nos que ele sabe muito bem distinguir aquilo que deve apoiar ou rejeitar para compor os quadros elitistas, todavia, posicionou-se de maneira enviesada não replicando as fórmulas europeias docilmente aprendidas e reproduzidas por muitos escritores de sua geração. Em meio à produção literária brasileira, das duas últimas décadas do século XIX e duas primeiras do século seguinte, perdurou tenazmente a poética do Parnasianismo (BOSI, 2006, p. 219-220) ${ }^{46}$. Concederam vida longa aos traços parnasianos, sobretudo, os poetas Olavo Bilac (1865-1918), Alberto de Oliveira (1857-1937) e Raimundo Correia (18591911) que compunham a chamada "tríade parnasiana". É digno de nota registrar que esses três escritores foram membros fundadores da Academia Brasileira de Letras, portanto, representantes oficias da literatura brasileira.

De berço francês, o Parnasianismo caracterizou-se pelo "gosto da descrição nítida (a mimese pela mimese), concepções tradicionalistas sobre metro, ritmo e rima e, no fundo, o ideal da impessoalidade que partilhavam com os realistas do tempo" (Ibid., p. 219-220). Tendo em vista essas concepções, a literatura oficial apresentava caráter mais diletante, definida por Afrânio Peixoto (1876-1947) (Apud SILVA, 2006, p. 47) como sendo "o sorriso da sociedade", figurava no sentido de "espelhar a vida airada de uma sociedade sem grandes preocupações ou desafios" (Ibid., p. 48). Representante maior dessa literatura

\footnotetext{
${ }^{46}$ Não ignoramos o Simbolismo, escola que, numa perspectiva didática dos movimentos literários, sucedeu o Parnasianismo. Contudo, apoiados aqui em Bosi (2006), nossa intenção foi a de reconhecer o relevo e permanência da concepção parnasianista no Brasil. Vale dizer que o Parnasianismo foi versado na poesia, sendo contemporâneo da prosa naturalista. A respeito do Naturalismo, trataremos logo adiante.
} 
oficial foi Coelho Neto (1864-1934), também membro fundador da Academia Brasileira de Letras, alçado a escritor mais lido durante muitos anos, tendo sido nomeado em 1928, em votação aberta ao público promovida pela revista carioca $\mathrm{O}$ Malho ${ }^{47}$, o "príncipe dos prosadores brasileiros". Para ele, a literatura se apresentava como "um reflexo perfeito da sociedade feliz" (Ibid., p. 49); pautado na arte contemplativa preferia temas mais amenos. Oposto às concepções de Coelho Neto, posicionou-se Lima Barreto, para quem a literatura caracterizava-se pelo viés militante, primordialmente como fenômeno social. Expressão clara das diferentes concepções de um e outro encontra-se no artigo "Qualquer coisa" (BARRETO, 1956b, p. 259-262), ocasião em que Lima comentou a atuação intelectual de Coelho Neto, contrastando o modo como concebiam a literatura.

\begin{abstract}
Não posso compreender que a literatura consista no culto do dicionário; não posso compreender que ela se resuma em elucidações mais ou menos felizes dos estados d'alma das meninas de Botafogo ou de Petrópolis; não posso compreender que, quando não for esta última coisa, sejam narrações de coisas de sertanejos; não posso compreender que ela não seja uma literatura de ação sobre as ideias e costumes; não posso compreender que ela me exclua dos seus personagens nobres ou não, e só trate de Coelho Neto; não posso compreender que ela seja caminho para se arranjar empregos rendosos ou lugares na representação nacional; não posso compreender que ela se desfaça em ternuras por Mme. Y, que brigou com o amante, e condene a criada que furtou uns alfinetes - são, pois, todas essas razões e motivos que me levam a temer que a ditadura de Coelho Neto me seja particularmente nociva (BARRETO, 1956b, p. 261).
\end{abstract}

Nesse ponto, parece-nos válido apontar a perspectiva adotada por Lima como contra-hegemônica, na medida em que propôs outro modelo de fazer literário, seguramente, com a intenção de combater um modelo que julgava

\footnotetext{
${ }^{47}$ Alguns números dessa revista foram digitalizados pela Biblioteca Nacional, encontram-se disponíveis em: http://objdigital.bn.br/acervo_digital/div_periodicos/malho/anuario_malho.htm.
} 
inadequado à realidade brasileira. Ainda que clivada, por aderir ora mais, ora menos aos moldes estrangeiros, conforme atestou 0 diálogo com as referências francesas, pode-se dizer que Lima sustentou postura contrahegemônica rumo à formulação de novo movimento literário. As palavras de Bosi elucidam a guinada literária com vistas ao Modernismo:

Caberia ao romance de Lima Barreto e de Graça Aranha, ao largo ensaísmo social de Euclides, Alberto Torres, Oliveira Viana e Manuel Bonfim, e à vivência brasileira de Monteiro Lobato o papel histórico de mover as águas estagnadas da belle époque, revelando, antes dos modernistas, as tenções que sofria a vida nacional (BOSI, 2006, p. 306-307).

Lima tinha consciência de que reproduzir o modelo vigente da literatura oficial "significava deixar para trás aquilo que muitos na elite carioca viam como um passado colonial atrasado, e condenar os aspectos raciais e culturais da realidade carioca que a elite associava àquele passado" (NEEDELL, op. cit., p. 70). Do legado europeu, aproveitou apenas os aspectos cujo préstimo fosse o de analisar o contexto local em sua essencialidade, ou seja, livre de um presente forjado pelas bastardas tradições europeias que forçavam as consciências a negarem as tradições efetivamente brasileiras, como ocorreu com a densa contribuição africana. A posição de Lima assemelha acordar-se com o que diz Abdala Júnior (2007, p. 50) sobre a consciência crítica dos escritores engajados que "procuram descartar formas de apropriação que possam deslocá-las para questões que os afastariam do trabalho artístico sobre temas relativos às carências reais de nossos povos", visto focalizar, por exemplo, a condição do pobre, do negro na sociedade brasileira em seu fazer literário, contrário à opção de apagamento dessa temática escamoteada pela elite intelectual à época, primordialmente voltada para a legitimação dos 
valores do Velho Mundo.

Não obstante a lucidez intelectual de Lima, os modelos franceses, indubitavelmente, percutiram em sua formação, referencial cuja importância assim pode ser estimada:

Ninguém pode questionar a afirmação de Goethe que a literatura alemã constitui o grande abrigo da literatura mundial. No entanto, a França pode ser considerada a origem acadêmica e o centro da história da literatura comparada moderna. A França exerceu a influência mais antiga e significativa sobre a vida literária dos povos e tem sido, de um modo geral, o manancial das ideias que marcaram a história nos últimos 250 anos (COUTINHO; CARVALHAL, op. cit., p. 53).

Não causa espanto, pois, que o grande projeto literário de Lima Barreto estivesse relacionado com um modelo francês. Passemos a analisá-lo sem perder de vista, porém, sua posição contra-hegemônica que se processou de modo a lutar contra a mera assimilação dos reputados modelos franceses pela consciência nacional, inclinada a desprezar os elementos locais de nossa constituição. 


\subsection{O Germinal Negro}

A apresentação do que seria a obra-prima de Lima Barreto dá-se no início do Diário, em 1903, quando declara: "[n]o futuro, escreverei a História da Escravidão Negra no Brasil e sua influência na nossa nacionalidade" (DI, p. 33 - 1903). O título revela a veemência do projeto, cuja elaboração demandaria fôlego longo, já que implicaria investigação histórica apurada. Passados dois anos, Lima voltaria a referir-se ao seu projeto, dessa vez de modo mais detalhado:

\footnotetext{
Veio-me a idéia, ou antes, registro aqui uma idéia que me está perseguindo. Pretendo fazer um romance em que se descrevam a vida e o trabalho dos negros numa fazenda. Será uma espécie de Germinal negro, com mais psicologia especial e maior sopro de epopéia. Animará um drama sombrio, trágico e misterioso, como os do tempo da escravidão $(D I$, p. $84-12$ de janeiro de 1905).
}

Nessa passagem, encontra-se delineado o modelo literário que the serviria como base estrutural de sua obra - O Germinal [Le Germinal]. Por essa razão, nos estenderemos a respeito dessa referência com o intuito de melhor compreendermos o projeto limabarretiano.

O Germinal, publicado, em 1885, pelo escritor francês Émile Zola (18401902), narra as miseráveis condições de trabalho dos mineiros de Lille, cidade localizada ao norte da França. A minúcia das descrições do cotidiano dos personagens impressiona pela riqueza de detalhes que desnudam a escassez em todos os âmbitos da vida: social, afetivo, econômico. A relação com o capital norteia todas as relações, desde a familiar até, como não poderia deixar de ser, entre patrão e empregado. O enredo salienta o início da luta de classes entre proletariado e burguesia. Focalizando, inicialmente, o personagem 
Étienne Lantier, um maquinista desempregado, o espaço da mina de carvão e seus trabalhadores aos poucos nos são apresentados. Dos personagens, destacamos a numerosa família Maheu, cujos descendentes trabalhavam na mina há cento e seis anos, segundo conta o velho Boa Morte. Dos Maheu, empregava-se na mina, além do velho Boa Morte (o avô), seu filho (Maheu) e mais três netos (Zacharie, de 21 anos; Catherine, de 15 e Jeanlin, de 11 anos).

Ao longo da narrativa, o autor surpreende os leitores por meio de sucessivas e intermináveis catástrofes elaboradas de modo assustadoramente verossímil, revelando a dura realidade de um grupo social submetido ao poderio econômico dos donos da Companhia das Minas de Montsou. Vale sublinhar que Zola trabalhara durante dois meses, antes de escrever essa obra, numa mina de carvão, momento em que pôde vivenciar o cotidiano dos mineiros, posteriormente descrito de forma bastante realista nesse romance.

Ora, Lima também desejava escrever um "drama sombrio", o espaço, pois, seria diferente - 0 das senzalas, já que seu intuito era 0 de retratar 0 cotidiano miserável dos escravos no Brasil. Logo, a dimensão trágica presente na obra de Zola, certamente, comporia a obra de Lima tingida ainda de "maior sopro de epopéia".

Nome do primeiro mês da primavera no calendário da Revolução Francesa, germinal, sinaliza para um sentimento utópico sustentado por Zola que acreditava na modificação da ordem social do mundo por meio da revolução, como as últimas linhas dessa obra deixam transparecer: "[o]s homens brotavam, era um exército coberto de carvão, vingador, que germinava lentamente da terra, para crescer nas colheitas do século seguinte. A germinação daquele exército logo faria explodir a terra" (ZOLA, 2000, p. 238). 
O final da narrativa, portanto, sinaliza para a esperança de melhores condições de vida para os trabalhadores.

À maneira de Zola, acreditamos que da obra de Lima ecoaria parecido tom utópico, dadas as convicções literárias limabarretianas, cujo norte aponta para a tentativa de romper com os modismos literários difundidos por uma elite que desconsiderava a figura do negro. Atualizaria, assim, o modelo francês com vistas nos aspectos sociais do contexto brasileiro. Pareceu partir daquilo que nos era alheio para construir algo que nos fosse próprio, transformando ao seu modo o modelo estrangeiro, contemplando as diferenças originais da matriz brasileira. Ou seja, seu ponto de partida foi o modelo importado, todavia, visou preenchê-lo com matéria nova extraída da realidade local.

À época na qual $O$ Germinal fora publicado na França, o romance não foi bem recebido, dado as inovações literárias apresentadas: linguagem popular, narrativa realista e cruel. À Zola atribui-se o estabelecimento da escola naturalista, visto que fundamentou seus romances na pesquisa de cunho sociológico e científico. A respeito de seu método, relatou Sodré:

Parecia-lhe que esse acúmulo extraordinário de elementos, esses dados colhidos diretamente e em quantidade continham a verdade inteira, reduziam ou eliminavam as possibilidades de erro ou deformação na transposição das cenas. Essa infatigável busca destinava-se à elaboração de uma das peças fundamentais da ficção naturalista, o meio, herdado dos ensinamentos de Taine. Misturado com a hereditariedade, constituía, sistematicamente, a fórmula verídica, o segredo da realidade (SODRÉ, 1992, p. 50).

Para os célebres críticos literários brasileiros dos idos do final do século XIX, Sílvio Romero (1851-1914) e José Veríssimo, Zola foi um eminente continuador do Naturalismo, não Ihe atribuíram o papel de iniciador do 
movimento (CANDIDO, 1978, p. 85/ VERÍSSIMO, 1977, p. 192): "[n]a crítica foi antecedido por Sainte-Beuve, Scherer e Taine; no romance por Balzac, Stendhal, Duranty, Flaubert, os Goncourt e Daudet "(CANDIDO, 1978, p. 85), reconheceu Romero.

A teoria evolucionista de Charles Darwin ${ }^{48}$ (1809-1882) assemelha ter marcado profundamente o autor de Germinal, assim como o livro do fisiologista francês Claude Bernard (1813-1878), Introdução ao estudo da medicina experimental [Introduction à l'étude de la médecine expérimentale $]^{49}$, publicado em 1865. Decidido a imprimir em sua prosa o rigor científico, Zola planejou compor uma série de romances nomeada Os Rougon-Macquart, iniciada em 1871 e concluída passados quatorze anos, com o livro O doutor Pascal (1895). Nessa série, composta por vinte romances, cujo eixo movimentou-se em torno da história social de uma família durante o Segundo Império francês, predominou o postulado determinista, segundo o qual a evolução biológica e a hereditariedade física e social condicionavam a vida humana. O Germinal é considerado a obra-prima dessa série.

Os acontecimentos focalizados em $O$ Germinal situam-se entre os anos de 1866-1867, momento de muitas agitações sociais no Velho Mundo. Nesse período, a insatisfação das classes menos favorecidas crescia a cada dia, culminando com a fundação, em 1864, da Associação Internacional dos Trabalhadores, mais conhecida como Primeira Internacional, em Londres, cujo principal líder foi Karl Marx ${ }^{50}$ (1818-1883). Lembremos que em 1789 se dera a

\footnotetext{
${ }^{48}$ Data de 1859, A Origem das Espécies, obra que introduz a ideia de evolução a partir de um ancestral comum por meio da seleção natural.

${ }^{49}$ Nesse livro, Claude Bernard estabelece as diferenças entre as ciências de observação e de experimentação. Conclui que a experiência é uma observação provocada.

${ }^{50}$ Em 1848, fora publicado o Manifesto do Partido Comunista escrito por Marx e Engels.
} 
Revolução Francesa, levando à queda da nobreza e elevando a burguesia a classe dominante. A essa, se seguiram muitas reviravoltas na França: a instituição do império de Napoleão Bonaparte, de 1799 a 1814, o restabelecimento da monarquia com o rei Carlos X, de 1824 a 1830, a revolução de 1848 que firmou a República, seguida de golpe de Estado em 1852, com Luís Napoleão autoproclamado imperador, reinando de 1852 a 1870 (Segundo Império). Após a derrota francesa na Guerra Franco-Prussiana, em 1870, a República foi novamente proclamada, no dia quatro de julho desse mesmo ano. Passado menos de doze meses, eclodiu nova tentativa de revolução popular com a Comuna de Paris (março de 1871).

Nesse período, no qual se desenrolou a narrativa de $O$ Germinal, o Brasil, do mesmo modo que a França, tinha o seu segundo monarca - D. Pedro II. Por aqui, prevalecia o regime escravocrata.

No que concerne à literatura, vislumbrava, na França, o ideário realista. Se o romantismo caracterizou-se pelo domínio das emoções, o realismo contrapôs-se aos ideais românticos à medida que buscou aproximar fielmente da realidade os fatos narrados numa explosão de emoções, sensações vibrantes. O naturalismo foi, pois, a radicalização do modelo realista. Contribuíram para o surgimento do movimento naturalista as descobertas das ciências naturais, bem como o estilo realista do autor de Madame Bovary, aliado ao positivismo de Taine. Pautados no princípio de que o ambiente e a herança genética determinavam o destino do indivíduo, os romances naturalistas apresentavam um quadro vivo dos seres focalizados destacando seus desejos e emoções explosivas com ênfase no contexto social no qual estes se encontravam inseridos. Holanda assim definiu esse movimento: 
O Naturalismo é a forma de realismo em que os sentimentos e a conduta dos personagens são relacionados com os fatores do meio, da herança, dos instintos, que os condicionam segundo um determinismo mais ou menos rígido. A ficção brasileira renovadora obedeceu em grande parte a este rumo, influenciada sobretudo por Emílio Zola e Eça de Queiroz (HOLANDA, 2004a, p. 411).

Zola influenciou escritores de todo o mundo. No Brasil, as primeiras publicações de cunho naturalistas se deram por volta de 1880. O primeiro romance de maior destaque foi $O$ mulato (1881) do escritor maranhense Aluisio de Azevedo (1857-1913) que teve "o mais simpático acolhimento do Rio de Janeiro e do país em geral" (VERÍSSIMO, 1998, p. 349). Passados nove anos, esse mesmo autor publicou $O$ cortiço, título também de grande sucesso de público à época.

É notável destacar a importância do escritor português Eça de Queiroz (1845-1900), considerado por Machado de Assis fiel discípulo de Zola e o iniciador do realismo em língua portuguesa.

Víamos aparecer na nossa língua um realista sem rebuço, sem atenuações, sem melindres, resoluto a vibrar o camartelo no mármore da outra escola, que aos olhos do Sr. Eça de Queiroz parecia uma simples ruína, uma tradição acabada. Não se conhecia no nosso idioma aquela reprodução fotográfica e servil das coisas mínimas e ignóbeis (ASSIS, 1961, p. 156).

Veríssimo, semelhantemente, também assinalou a atuação de Eça na reprodução do modelo zolaniano.

Os verdadeiros naturalistas segundo as receitas francesas já aviadas em Portugal por Eça de Queiroz e seus discípulos vieram depois, quando esses últimos românticos iam em meio da sua carreira literária, e até quando o naturalismo entrava já a declinar em França (VERÍSSIMO, 1998, p. 346). 
Embora Machado tenha chamado de realismo o movimento literário que sucedeu a escola romântica, diferente de Romero que denominou de naturalismo a maneira de encarar a literatura após o romantismo, segundo ele, nome mais apropriado do que realismo (CANDIDO, 1978, p. 83), ambos parecem aludirem a um mesmo modo de composição literária focado nos aspectos da realidade, nas secreções sociais salpicadas pelas páginas. Esse modo de proceder no fazer literário foi depreciado tanto por Machado, quanto por Romero e Veríssimo.

Nesse sentido, ao buscar descrever o novo espírito que marcava uma nova geração poética na década de 1870, Machado (op. cit., p. 188) afirmou que o realismo era "a negação mesma do princípio da arte" ${ }^{\text {"; }}$; além de ter empreendido consistente crítica ao modo como Eça de Queiroz compôs $O$ Primo Basílio (1878), pautado nos princípios realistas ${ }^{52}$. Romero, por sua vez, ao realizar um balanço intelectual do país ao longo de 1888, destacou os romances lançados nesse ano, a saber - A carne, de Julio Ribeiro (1845-1890); Ateneu, de Raul Pompéia (1863-1895); Cromo, de Horácio de Carvalho (18571933); Hortência, de Marques de Carvalho (1866-1919) e Homem, lançado no ano anterior (1887), do já referido Aluisio de Azevedo. Da observação dessas obras, marcou o próximo parentesco entre elas, com exceção do Ateneu, pois disse que Pompéia "não esta[va] ele preso ao naturalismo estreito e estéril da escola de Zola, cujos romances fazem na literatura [...] o papel da mediocridade charlatanesca, enganadora e pretensiosa" (CANDIDO, 1978, p. 115, grifos nossos). Eis aí como Romero encarou o naturalismo à la Zola. E

\footnotetext{
${ }^{51}$ Cf. artigo "A nova geração", publicado originalmente na Revista Brasileira, 1879.

${ }^{52}$ Cf. artigo "O Primo Basílio", publicado originalmente em O Cruzeiro, de 30 de abril de 1878.
} 
completou, chamando esse naturalismo, do modo como o entenderam no Brasil, de "sistematização do mal" (Ibid., p. 115). Por fim, resta-nos verificar a opinião de Veríssimo que se concentrou em observar a contribuição do naturalismo para o desenvolvimento das nossas letras. Contrapondo-o ao romantismo, esse crítico considerou que

[...] mais e pior ainda que o romantismo, o naturalismo brasileiro, deslumbrado por um certo aspecto da escola e pela grande personalidade de um homem [Zola], desprezou ver com o seu próprio temperamento este nosso canto da natureza e abdicou a sua originalidade nas mãos de Zola. É pois, e os será ainda por muito tempo, a fatal imitação, que atrasará o definitivo advento de uma verdadeira e forte literatura brasileira onde o povo se sinta representado e a pátria se veja reproduzida (VERÍSSIMO, 1977, p. 202).

Concluiu, portanto, que o naturalismo não corroborou para afirmação de nossa identidade, eis o porquê de ter classificado essa escola como "a menos nacional das nossas escolas literárias" (Ibid., p. 208).

No tocante à notoriedade de Zola, interessa-nos refletir acerca das intenções de Lima ao escrever o seu Germinal negro, tal qual explicitado nas páginas íntimas:

Ah! Se eu alcanço realizar essa ideia, que glória também! Enorme, extraordinária e - quem sabe - uma fama europeia.

Dirão que é o negrismo, que é um novo indianismo, e a proximidade simplesmente aparente das cousas turbará todos os espíritos em meu desfavor; e eu pobre, sem fortes auxílios, com fracas amizades, como poderei viver perseguido, amargurado, debicado? (DI, p. 84 - 12 de janeiro de 1905).

Ficam aqui evidentes as aspirações de Lima que desejava marcar a história da literatura brasileira, criando uma nova escola - o negrismo ${ }^{53}$, que

\footnotetext{
${ }^{53}$ Notamos aqui o vanguardismo de Lima Barreto ao pensar em negrismo como vocábulo que desse conta de exprimir o sentimento ou a vivência íntima do negro, tal como, três décadas
} 
seria talvez comparado, conforme descreveu, à distinta vertente literária - o indianismo, uma das peculiaridades do Romantismo brasileiro, alusivo à idealização do indígena.

\begin{abstract}
A importância e a influência do Indianismo foram historicamente inestimáveis, como instrumento de aquisição da consciência nacional num povo que acabava de chegar à vida independente. Entroncando numa tradição literária que vinha do século XVIII, correspondendo a uma certa linha de prosápia genealógica, configurado pelas influências estrangeiras do exotismo literário - ele foi uma espécie de grande sinal de identificação para todos os brasileiros, que projetaram na raça indígena o seu passado, a sua mestiçagem, a grandiloqüência dos seus sonhos (HOLANDA, 2004a, p. 404).
\end{abstract}

Desse modo, se no indianismo romântico, figurou o índio como herói nacional, exaltado em prosa e verso em terras tupiniquins especialmente pela pena de José de Alencar (1829-1877) ${ }^{54}$, o negrismo limabarretiano enalteceria, por sua vez, o negro, firmando-o como protagonista em solo auriverde. Lançálo-ia como estandarte da jovem nação, comprovando que a perspectiva criativa de Lima se encontrava ligada aos aspectos que nos eram próprios. Consciente do escândalo que tal feito provocaria, dado a nulidade imputada à figura do negro, apesar do significativo contingente que por aqui existia e da relevância de seu papel na construção nacional, Lima se pôs apreendido diante da depois, o poeta martinicano Aimé Césaire (1913-2008) propôs com a palavra négritude,
registrada pela primeira vez em seu livro Cahier d'un retour au pays natal (1939). No Brasil, a
palavra negritude, segundo Ferreira (2006, p. 173), "esteve ausente dos dicionários brasileiros
até 1975 , data em que seria consagrada como 'termo corrente da língua portuguesa' a partir da
primeira edição do Dicionário Aurélio [...]". Além da palavra negritude, Ferreira observou as
ocorrências e significados também de duas outras: negridade e negrícia, que apareceram em
seu corpus de análise e àquela se ligam por parentesco semântico. Para melhor compreensão
desses vocábulos, cf. FERREIRA, 2006, p. 163-183. Notamos ainda que o vocábulo negrismo
não se encontra registrado nos dicionários de Houaiss (2003), Ferreira (1999) e Caldas Aulete
(1964), tendo sido contemplado pelo Dicionário Brasileiro da Língua Portuguesa (2000), que
oferece a seguinte definição: "tendência de representar na literatura, ou nas artes em geral,
ideias, sentimentos ou costumes dos negros".
54 Destacamos os célebres romances alencarianos: O Guarani (1857), Iracema (1865) e
Ubirajara (1874). 
realidade de um país norteado pelos postulados raciais, adágios da Europa. Abdala Júnior (op. cit.), ao examinar os contextos para ruptura, destacou que o escritor engajado deve necessariamente ter "consciência crítica dos processos literários que utiliza". E apontou, apoiado em Walter Benjamin, a necessidade do autor de repensar sua posição no bojo da produção de sua obra, ato que

[...] pede ao escritor engajado a consciência do risco histórico de que participa. Esse momento histórico solicita-lhe uma atitude de atrevimento, para que articule novas configurações formais em oposição às marcas de conformismo que podem neutralizar o novo imaginário político (Ibid., p. 43).

Ora, Lima apresentou essa faculdade de julgar o alcance de sua obra dado as proporções de seu atrevido projeto, movido por viés político-ideológico.

Sobressaí-se ainda da nota limabarretiana supracitada a questão do apadrinhamento, da importância de certas amizades não apenas para se alcançar um objetivo, como para proteger-se de possíveis ataques. A estrutura dessa "socialização associada ao exercício de poder", como nomeou Needell (op. cit.), corolário do modus operandi da sociedade europeia, foi assim descrita:

\begin{abstract}
As relações no âmbito do "alto mundo", nas quais o apadrinhamento desempenhava um papel central, eram ordenadas e reforçadas pela etiqueta elaborada fora do país, com este objetivo. Assim, a socialização por intermédio de práticas culturais não apenas proporcionava o status conferido pela aquisição de atributos aristocráticos europeus, como também intensificava o uso do poder para a manutenção e promoção das relações sociais tradicionais em meio às circunstâncias sócio-econômicas vigentes (NEEDELL, op. cit., p. 159).
\end{abstract}

Daí a interrogação de Lima ao final da passagem acima citada, visto repugná-lo "usar os famosos pistolões" (BARRETO, 1956b, p. 282). Não se 
sujeitando, portanto, a esse tipo de relação de favor, antes adotou postura de enfrentamento ao sustentar com veemência suas convicções, dando de ombros ao compadrio alheio. Expressão consciente desse posicionamento pode ser observada na nota de advertência de Bagatelas, reunião de artigos diversos, quando afirmou: "quero que as inimizades que eles [os artigos] possam ter provocado contra mim, se consolidem, porquanto, com Santo Inácio de Loyola, penso que não há inimigo tão perigoso como não ter absolutamente inimigo" (BARRETO, 1961a, p. 37).

Não deixou, contudo, de exprimir os receios que the afligiam:

Temo muito pôr em papel impresso a minha literatura. Essas ideias que me perseguem de pintar e fazer a vida escrava com os processos modernos do romance, e o grande amor que me inspira - pudera! - a gente negra, virá, eu prevejo, trazer-me amargos dissabores, descomposturas, que não sei se poderei me pôr acima delas (DI, p. 84 - 12 de janeiro de 1905).

Seguiu, pois, dizendo:

Mas... e a glória e o imenso serviço que prestarei a minha gente e a parte da raça a que pertenço. Tentarei e seguirei avante. "Alea jacta est".

Se eu conseguir ler esta nota, daqui a vinte anos, satisfeito, terei orgulho de viver!

Deus me ajude! (DI, p. 84 - 12 de janeiro de 1905).

Concluiu essa expansão íntima de maneira entusiasta, impelido pela ânsia de escrever sobre o passado de nossa gente com a intenção de conceder ao negro outro lugar na elitista organização nacional.

Articulando todos esses elementos, verificamos o alcance do projeto de Lima, que visava muito além do renome intelectual. Fica claro contra o que queria lutar - contra as injustiças sociais, humilhações e ofensas perpetradas 
contra o negro e foi, a nosso ver, esse "termômetro nervoso", para usar a expressão de Schwarcz (BARRETO, 2010b, p. 15), que fez brotar o gérmen do combate político-ideológico que figuraria em seu Germinal negro.

Lançara-se a sorte, como disse ele em latim "Alea jacta est", a partir do momento em que the veio a ideia de escrever essa obra. Contudo, os meandros da vida não Ihe foram favoráveis. Tolhido por fortuna adversa, não conseguiu dar cabo ao seu projeto, adiado para a maturidade: "[c]omo exija pesquisa variada de impressões e eu queira que esse livro seja, se eu puder ter uma, a minha obra-prima, adiá-lo-ei para mais tarde" (DI, p. $84-12$ de janeiro de 1905). Não teve, portanto, a ventura de colher os louros que essa obra poderia dar-Ihe em vida, visto acreditava que "uma grande vida é um projeto da juventude realizado na maturidade"55 (DI, p. 84 - 12 de janeiro de 1905, tradução nossa), restando-Ihe apenas amarguras e decepções.

Ainda em 1905, em inscrição não datada, voltou a referir-se a esse projeto idealizado: "[s]eria uma bela obra um romance em que se tratasse a antiga fazenda com escravos..." (DI, p. 105 - 1905). Vemos aí percutir essa ideia ao longo desse ano. Esse projeto acorda-se perfeitamente às concepções literárias de seu autor que podem ser melhor observadas no texto "O Destino da Literatura". Passemos a examiná-lo a fim de entrevermos a posição sustentada por Lima no plano intelectual com vistas em seu projeto literário.

\footnotetext{
${ }^{55}$ Lima citou essa frase em francês: "une grande vie est une pensée de la jeunesse réalisé par l'âge mûr". Não informou fonte. Verificamos tratar-se de um pensamento do poeta francês Alfred de Vigny (1797-1863), que disse: «Amis, qu'est-ce qu'une grande vie, sinon une pensée de la jeunesse exécutée par l'âge mûr. ». Disponível em: http://www.dico-citations.com/amisqu-est-ce-qu-une-grande-vie-sinon-une-pens-e-de-la-jeunesse-ex-cut-e-par-l-ge-m-r-vignyalfred-de/.
} 


\subsection{O Destino da Literatura para Lima Barreto}

Publicado em 1921, na Revista Sousa Cruz, o texto "O Destino da Literatura" foi escrito com o intuito de ser proferido numa conferência em Rio Preto, fato que acabou não ocorrendo, já que no dia Lima desaparecera misteriosamente, sendo encontrado bêbado pelo seu amigo Ranulfo Prata ${ }^{56}$. Tal fuga pode ser explicada pelo caráter reservado do autor que confessou ser um "bicho-do-mato" (BARRETO, 1956b, p. 55), afirmando não possuir atributos de conferencista. Aliás, Lima iniciou esse texto destacando justamente as habilidades exigidas ao expositor: "desembaraço e graça, distinção de pessoa, capricho no vestuário e - quem sabe lá? - beleza física e sedução pessoal" (lbid., p. 51); destaque que aponta suas hesitações em apresentar uma conferência, visto presumidamente não apresentar as qualidades elencadas.

Lima, que via a arte como um fenômeno social, concentrou-se em discutir uma questão fundamental, que pode ser resumida com suas próprias palavras: "[e]m que pode a Literatura, ou a Arte contribuir para a felicidade de um povo, de uma nação, da humanidade, enfim?" (Ibid., p. 55-56). lluminando suas reflexões temos as formulações de Tolstói, Taine, Brunetière e Guyau, para citar os mais representativos, cujas definições sobre arte, beleza e literatura foram referidas de memória por Lima Barreto, já que, estando longe do Rio de Janeiro, não se encontrava em poder de seus livros e apontamentos, conforme advertiu aos seus interlocutores (Ibid., p. 57).

Ao seguir no encalço dessa questão, Lima pôs à vista as sólidas bases

\footnotetext{
${ }^{56}$ O médico e amigo Ranulfo Prata, com o objetivo de remediar o drama doméstico de Lima Barreto, convidou-o para passar uma temporada em Mirassol, cidade do interior paulista. Lá, os amigos de Prata propuseram a realização de uma conferência cujo tema seria o destino da literatura, que deveria acontecer em Rio Preto, cidade maior, próxima de Mirassol.
} 
sobre as quais se assentava seu fazer literário, exposição que revelou a coerência e potencialidade de seu pensamento. Para ele, a literatura deveria concentra-se em trazer à luz "[...] um certo e determinado pensamento de interesse humano, que fale do problema angustioso do nosso destino em face do Infinito e do Mistério que nos cerca, e aluda às questões de nossa conduta na vida" (Ibid., p. 59). O caráter prático que emana desse excerto justifica as temáticas que ocuparam as páginas íntimas e prosa limabarretianas - o sujeito marginalizado, a discussão racial, os modelos estrangeiros, as relações sociais. Questões que, sem dúvida, dizem respeito "à nossa conduta na vida". Nessa perspectiva, escrever o Germinal negro arremataria o conjunto em alinhavo da obra de Lima, costurado por uma fina capacidade analítica dos problemas prementes em nosso país.

Decorreu do poder creditado à literatura, sua completa entrega a essa arte, crença que gestou intensa produção ficcional, uma vez que o espaço da página branca representava para ele arena pública de combate. Vale acompanhar uma vez mais em suas palavras como definiu o poder da literatura, a citação é longa, mas a formulação que traz é lapidar:

Ela [a literatura] sempre fez baixar das altas regiões das abstrações da Filosofia e das inacessíveis revelações da Fé, para torná-las sensíveis a todos, as verdades que interessavam e interessam a perfeição da nossa sociedade; ela explicou e explica a dor dos humildes aos poderosos e as angustiosas dúvidas destes, àqueles; ela faz compreender, uns aos outros, as almas dos homens dos mais desencontrados nascimentos, das mais dispersas épocas, das mais divergentes raças; ela se apieda tanto do criminoso, do vagabundo, quanto de Napoleão prisioneiro ou de Maria Antonieta subindo à guilhotina; ela, não cansada de ligar as nossas almas, umas às outras, ainda nos liga à árvore, à flor, ao cão, ao rio, ao mar e à estrela inacessível; ela nos faz compreender o universo, a Terra, Deus e o Mistério que nos cerca, para o qual abre perspectivas infinitas de sonhos e de altos desejos (Ibid., p. 67). 
Concebida desse modo, a literatura teria a faculdade de apontar realidades, dimensionar aflições dos menos afortunados, gerar mútua compreensão. Observe-se, nesse sentido, que Lima não partiu de um ponto de vista individualista, antes visou construir uma humanidade mais solidária. Seria essa, portanto, a contribuição da literatura no destino da Humanidade. Sustentando essa posição, em 1916, no texto "Amplius"57, já havia afirmado ser o papel da literatura o de realizar "a comunhão dos homens de todas as raças e classes, fazendo que todos se compreendam, na infinita dor de serem homens, e se entendam sob o açoite da vida, para maior glória e perfeição da humanidade" (BARRETO, 2010b, p. 58); defendeu, como vemos, o mesmo argumento em ambos os textos: a função social da literatura.

Erigido a prumo sobre essas concepções repousou seu projeto literário de escrever a História da Escravidão Negra no Brasil. Por meio dessa obra, inflamaria talvez a discussão acerca do papel do negro em nossa nacionalidade. Conjugando certamente as condições racial, social e econômica em seu enredo, germinaria nas consciências a necessidade de novos rumos para a política nacional, por meio de uma nova ótica focalizando o negro no âmbito da construção de nossa identidade. Acreditamos ter sido este o propósito de Lima ao expor a ideia sobre seu Germinal, visto assumir-se enquanto negro tendo claro, portanto, o lugar de onde falava. Com efeito, as reflexões de Lima, autor que foi ativo ator social, revelam o "envolvimento consciente e marcado da pessoa do autor pela causa que abraça" (HOSSNE, op. cit., p. 58). Sob o prisma racial passaremos a analisá-las no capítulo que segue.

\footnotetext{
57 "Amplius" saiu em setembro de 1916 no jornal $A$ Época, escrito em resposta a uma carta anônima que recebera criticando sua obra Triste fim de Policarpo Quaresma. Serviu-se dessa ocasião para expor suas concepções literárias.
} 
Capítulo III

Brasil: O Projeto de Nação para um Povo Mestiço

"Não pararei nunca, não me deterei; nem a miséria, as perseguições, as descomposturas me deterão. Sacudi para longe o fantasma do medo; sou forte, penso, tenho coragem... Nada! Nada! Nada! É que senti que a ciência não é assim um cochicho de Deus aos homens da Europa sobre a misteriosa organização do mundo".

(Diário Íntimo) 


\section{Brasil: O Projeto de Nação para um Povo Mestiço}

O feito da independência do Brasil impôs a complexa tarefa de estabelecer um projeto de nação para organizar o país. Assim, em 1822, formou-se o Estado, sendo a identidade nacional a partir daí delineada de modo vacilante, dado nossa singular constituição racial. Com efeito, sobretudo no decorrer do século XIX, nosso país foi visto a partir da ótica racial, e muitos foram os naturalistas que por aqui passaram e registraram a miscigenação como um traço fortemente representativo de nosso povo, resultado do cruzamento entre brancos, índios e negros.

Dentre os pesquisadores viajantes, é significativo destacarmos a presença dos alemães Johann Baptiste von Spix (1781-1826) e Carl Friedrich Philipp von Martius (1794-1868) que empreenderam considerável pesquisa sobre nossa fauna e flora ao longo de três anos, originando a obra, em três tomos, Viagem pelo Brasil 1817-1820 [Reise in Brasilien]. Embora o olhar desses estudiosos estivesse voltado para a diversidade e exuberância da natureza, não deixaram de refletir sobre o estado civilizatório da terra brasilis, revelado por meio do grau de dominação do homem sobre a natureza. Escusado dizer que tinham em mente uma visão eurocêntrica de civilização, a qual atentava para as diferenças entre as raças e conferia ao europeu superioridade racial em relação ao negro e ao índio, postulados que justificavam a necessidade de nosso país civilizar-se. Essa visão de Spix e Martius contribuiu para a introdução, no âmbito dos estudos historiográficos brasileiros, dos quesitos raça e meio para análise da formação do jovem país. Acerca desses quesitos, discorreu Ortiz (2006, p. 16): "[n]a realidade, meio e 
raça se constituíam em categorias do conhecimento que definiam o quadro interpretativo da realidade brasileira".

A fim de prover a nova nação de quadros de pensamento próprio, uma vez que, politicamente independente, desvinculava-se da organização metropolitana, tratou-se logo de instituir por aqui pujantes estabelecimentos de ensino. Daí a necessidade de fundação das Faculdades de Direito (1827), de São Paulo e Recife bem como a reformulação das Faculdades de Medicina, da Bahia e Rio de Janeiro, que haviam sido criadas após a chegada de D. João (1808); além da criação do Instituto Histórico Geográfico Brasileiro (1838), situado também na capital da República. Essas instituições encerravam os aspectos fundamentais para a construção simbólica da identidade nacional, já que a primeira se ocuparia das leis, a segunda de cuidar da saúde e a última da memória da nação.

Profundamente vinculados à lógica e dinâmica que marcaram a independência política brasileira em 1822, já em seu momento de nascimento esses estabelecimentos pareciam responder à necessidade de confrontar quadros autônomos de atuação e de criar uma intelligentsia local apta a enfrentar os problemas específicos da nação (SCHWARCZ, 1993, p. 141).

Com o objetivo de premiar o melhor plano para a história do Brasil, em 1840, o Instituto Histórico Geográfico Brasileiro promoveu um concurso cujo trabalho vencedor foi a dissertação de Martius "Como se deve escrever a História do Brasil" ${ }^{58}$. Nesse trabalho, dos aspectos inicialmente apontados, que deveriam ser considerados nessa empreitada, avultou o quesito raça.

\footnotetext{
${ }^{58}$ Lima Barreto anotou referência bibliográfica desse texto de Martius: "Como se deve escrever a história do Brasil, tomo VI da Revista do Instituto Histórico" (DI, p. 147 - Sem data, 1910).
} 
São, porém estes elementos de natureza muito diversa, tendo a formação do homem convergido de um modo particular três raças, a saber: a de cor de cobre ou americana, a branca ou caucasiana, e enfim a preta ou etiópica. Do encontro, da mescla, das relações mútuas e mudanças dessas três raças, formou-se a atual população, cuja história por isso mesmo tem um cunho muito particular (MARTIUS, 1844, p. 187).

Corolário dessa linha de pensamento foram os trabalhos de Adolfo de Varnhagen (1816-1878), História Geral do Brasil (1855) e de Sílvio Romero, História da Literatura Brasileira (1888), nos quais "[a]mbos abraçaram a idéia da 'nação' como unidade racial e cultural, resultante do cruzamento das três raças, rumo ao progressivo branqueamento" (VENTURA, 1991, p. 42). As palavras de Romero confirmam o valor da natureza e da raça nesse período:

Há dois grandes motores que podem pesar fortemente na feitura de um caráter nacional: a natureza e a aglomeração de populações distintas. Os povos modificam-se pela natureza que os cerca; mas, para isto, são necessários muitos séculos (ROMERO, 2002, p. 45).

Pensar a história da nação, como vemos, desde os primeiros anos da Independência, passava indispensavelmente pela constituição racial de nosso povo. Cumpre-se contornar aqui a imagem que o Imperador esforçava-se para imprimir - a de um país mestiçado entre índios e portugueses. Os negros, por sua vez, não figuravam nas cenas nacionais do Império, sendo considerados como estrangeiros. Com efeito, coube ao índio o papel de protagonista desse projeto de nação, figura essencial para fundar um passado decoroso. Eleito pelo movimento romântico como ícone da brasilidade, acompanhamos a trajetória heróica do índio em obras fundamentais de nossa literatura, tais como O Guarani (1857), Iracema (1865), O Ubirajara (1874), de José de Alencar. 
Fazendo da literatura um exercício de patriotismo, esse gênero ganhava lugar nos planos do Estado. A valorização do pitoresco da paisagem e das gentes, do típico em vez do genérico, encontrava no indígena o símbolo privilegiado. Representando a imagem ideal, o indígena encarnava não só o mais autêntico como o mais "nobre", no sentido de se construir um passado honroso. Por oposição ao negro, que lembrava a escravidão, o indígena permitia indicar uma origem mítica e unificadora (SCHWARCZ, 2007, p. 140).

Os homens de letras buscaram, em elementos específicos da realidade local, cumprir com o intuito patriótico de criar uma literatura nacional que nos exprimisse. A figura do intelectual revestiu-se então de especial importância, pois passou a atuar junto ao Estado a fim de criar tradições a partir das obras, que veicularam discursos operantes de acordo com as representações positivas de civilização.

Nesse cenário, fazia-se urgente abolir a escravidão, prática condenada por muitos intelectuais, haja vista a voz do chamado "Patriarca da Independência", José Bonifácio (1763-1838), um ano após a proclamação da independência, que sustentou na Assembleia Constituinte uma representação visando à abolição da escravatura e à emancipação gradual dos escravos. A essa voz, muitas outras se sucederam alastrando pelo país as campanhas abolicionistas. A partir daí, sucessivas leis foram instituídas a fim de que, progressivamente, a escravidão fosse enfim extinta. Dessas leis, destacamos a Lei Eusébio de Queiroz (1850), que proibiu definitivamente o tráfico de escravos para o Brasil; a Lei do Ventre Livre (1871), que concedeu liberdade aos filhos de escravos nascidos a partir dessa data, mantendo-os, contudo, sob a tutela de seus senhores até completarem 21 anos; a Lei dos Sexagenários (1885), que concedeu liberdade aos escravos com mais de 60 anos. A respeito desse processo que culminou com a Lei Áurea (1888), descreveu Lima Barreto: 
A lei 13 de maio vinha de longe, era convicção da nação a injustiça da escravidão, não precisava jornalistas nem evangelizadores para mostrar-Ihe a injustiça. Quem notar basta fazê-lo de 1822 - as referências que os nossos governantes fazem à coisa, sente que eles o fazem com vergonha, com desazo, sentiam-no a ilegalidade, a injustiça; e esse sentimento, que se foi espalhando pelo país, aumentou extraordinariamente depois da guerra do Paraguai e foi como, se dando a lei de 1871, não teve para encarná-la senão o funcionário que a subscreveu, o visconde do Rio Branco, ministro naquele tempo. A lei dos sexagenários foi assim também (DI, p. 98 - 02 de fevereiro de 1905).

Sublinhamos a atuação de Joaquim Nabuco e de José do Patrocínio (1853-1905) que fundaram, no Rio de Janeiro, a Sociedade Brasileira contra a Escravidão (1880), bem como os esforços de agremiações positivistas e maçônicas, cujos representantes - advogados, jornalistas, intelectuais, políticos - engajaram-se na causa abolicionista. Participação fundamental, em São Paulo, teve a figura ímpar de Luiz Gama (1830-1882), advogando em favor da alforria de muitos escravos. No plano literário, é incontornável apontá-lo como voz inaugural do "negro-autor", para usar a expressão de Ferreira (GAMA, 2000, p. XV), que salientou:

A postura estética e existencial de Luiz Gama permitiu-lhe propor, pela primeira vez na literatura brasileira, uma contraideologia aos dogmas do pensamento racial dominante, como mais tarde se manifestaria, além do poeta simbolista [Cruz e Souza], em Lima Barreto (Ibid., p. XXIII).

O negro, nesse momento, enquanto tema de prosa e versos, figurava do ponto de vista do lamento diante da condição escrava, privado de liberdade e apartado de sua pátria. Matéria literária que nutriu os poemas abolicionistas de Castro Alves (1847-1871), conhecido por isso mesmo como "poeta dos 
escravos". Daí decorreu a originalidade de Luiz Gama ${ }^{59}$, que "fincaria uma voz diferenciada" (Ibid., p. XV), a do escritor negro que tomou posse da palavra para descrever a partir de observação própria, ou seja, enquanto sujeito de sua história, o modo como via e era visto socialmente, antecipando, portanto, a postura autoral de Lima Barreto.

No plano político, foi, sobretudo, após a abolição definitiva da escravatura que a questão racial tornou-se mais saliente, visto que a partir da assinatura da Lei Áurea ${ }^{60}$ o negro fora alçado à condição de cidadão livre, portanto, legalmente teria os mesmos direitos que os demais cidadãos brasileiros. Postura confirmada por Skidmore (1976, p. 12), que observou: "[a]ntes do clímax da abolição da escravidão no Brasil, em 1888, a maior parte da sua elite pouca atenção dava ao problema da raça em si, bem como a relação entre as características raciais do país e seu desenvolvimento futuro".

Diante desse fato irrevogável - a abolição - uma nova realidade se impôs à sociedade brasileira, em face da qual figurou um questionamento indigesto: como inserir os escravos recém libertos, sujeitos até há pouco propriedades dos senhores, nesta sociedade hierarquizada agrilhoada por uma estrutura escravista? Como integrar os "ex-animais de trabalho" e considerálos, então, humanos ${ }^{61}$ ? Com efeito, "[n]a sua condição de propriedade, o

\footnotetext{
${ }^{59}$ Chamamos atenção para a publicação, em 1859, em São Paulo, da obra de Luiz Gama Primeiras trovas burlescas de Getulino - coletânea de poemas satíricos políticos. Passados dois anos, sairia uma segunda edição "correcta e augmentada" na capital da República (GAMA, 2000, p. XXV).

${ }^{60}$ É válido dizer que, quando por aqui se decretou o fim da escravidão, há muito os países vizinhos ao Brasil a haviam abolido, a exemplo do Chile (1823), México (1829), Venezuela e Peru (1854).

${ }^{61}$ A respeito da animalização dos escravos, Lima Barreto registrou "A ordenação do Reino (manuelina) que equipara as bestas aos escravos é encontrada no livro IV, título xvi" ( $D I$, p. 211 - Sem data, 1920). As ordenações manuelinas designaram a nova codificação promulgada por D. Manuel (1469-1521). Em 1514, fez-se a primeira edição completa dos cinco livros das Ordenações Manuelinas, cuja versão definitiva foi publicada em 1521. Essas ordenações estão
} 
escravo [era] uma coisa, um bem objetivo" (GORENDER, 1988, p. 49). A resposta encontrada para essas questões foi a adoção negociada das teorias raciais formuladas por teóricos europeus originalmente para justificar o imperialismo do velho mundo: "[a] 'superioridade' da civilização europeia torn[ou]-se assim decorrente das leis naturais que orientariam a história dos povos" (ORTIZ, op. cit., p. 14). Mascarou-se o que se acreditava ser "o caráter inato das diferenças raciais e a degenerescência dos sangues mestiços" (SKIDMORE, op. cit., p. 94) para entabular, assim, uma solução original para o caráter mestiço de nosso país. A mestiçagem foi encarada como possibilidade redentora para o embranquecimento do povo brasileiro.

Por aqui, os modelos deterministas raciais mantiveram-se em auge principalmente ao longo dos anos de 1870 a 1930, servindo às elites a fim de nortear as ações políticas.

\begin{abstract}
Como acontece geralmente na maioria dos países colonizados, a elite brasileira do fim do século XIX e início do século $X X$ foi buscar seus quadros de pensamento na ciência europeia ocidental, tida como desenvolvida, para poder não apenas teorizar e explicar a situação racial do seu País, mas também, e sobretudo, propor caminhos para a construção de sua nacionalidade, tida como problemática por causa da diversidade racial (MUNANGA, 2008, p. 47).
\end{abstract}

A precisa formulação de Ventura destacou as contradições da aplicação desses modelos num país, cuja nação era essencialmente mestiça:

O racismo científico assumiu uma função interna, não coincidente com os interesses imperialistas, e se

disponíveis na íntegra em: http://www.ci.uc.pt/ihti/proj/manuelinas/14p49.htm. A ordenação referida por Lima trata-se do "Livro 4 Tit. 16: Como se podem engeitar os escravos, e bestas, por os acharem doentes ou mancos". 
transformou em instrumento conservador e autoritário de definição da identidade social da classe senhoril e dos grupos dirigentes, perante uma população considerada étnica e culturalmente inferior (VENTURA, op. cit., p. 60).

Não podemos deixar de salientar o impacto causado pelas teorias raciais vindas da Europa, mais precisamente a contar do final do século XIX e início do XX, adotadas aqui na tentativa de construir uma identidade nacional respaldada cientificamente pela ciência europeia. Os rumos dados à nação perpassaram pela diversidade racial premente em solo auriverde. Foi nesse cenário que se movimentou Lima Barreto. Tendo em vista que suas reflexões no Diário Íntimo abordaram o complexo e escorregadio problema da identidade nacional, considerando a condição social do negro na sociedade brasileira no início do século XX, apresentaremos, em um primeiro momento, as principais teorias e nomes que compuseram o repertório limabarretiano no tocante à discussão racial. No segundo momento, é nossa intenção usar suas notas para pensar no modo como Lima se viu atingido pelos desdobramentos dessas teorias e, por extensão, como observou outros sujeitos que partilhavam da mesma condição racial serem igualmente afetados. Atentaremos, portanto, para o olhar de Lima sobre si e sobre o outro. Nesse ponto, será imprescindível observar a forma como encarou e, em um movimento inverso, como foi encarado pela sociedade - arena pública. Considerando nosso corpus de análise, notas íntimas, não perderemos de vista a relação entre público e privado, tomado aqui no sentido de entrever o trânsito social-pessoal de Lima nos espaços por onde circulou - setores sociais, como os jornais, as letras e privado como a esfera familiar e o espaço subjetivo do diário. 


\subsection{A Falsa Medida das Teorias Raciais no Brasil}

A palavra raça é originária do italiano razza que, por sua vez, vem do latim ratio, "significa sorte, categoria, espécie", conforme definiu Munanga (2004, p. 17). Esse conceito usado inicialmente no campo das ciências naturais para classificar espécies animais e vegetais, gradativamente foi sendo ressignificado, até chegar a classificar a diversidade do gênero humano. Ao longo do século XVII, o conceito de raça passou a legitimar as relações de dominação e de sujeição entre as classes sociais, a exemplo dos francos e gauleses, no contexto francês, que se consideravam raças diferentes, embora fisicamente não houvesse distinções entre esses grupos. É digno de nota sublinhar a publicação da obra Nova divisão da terra pelas diferentes espécies ou raças que a habitam [Nouvelle division de la terre par les différentes espèces ou races qui l'habitent], em 1684, pelo estudioso francês François Bernier (16251688), primeiro a usar o termo raça para referir-se à diversidade humana. De fato, essa parece ter sido a primeira classificação moderna das diferentes raças humanas (Ibid., p. 17).

Classificar os indivíduos demandava critérios bem definidos, foi quando no século XVIII, estabeleceu-se a cor da pele como índice classificatório para a distinção das raças em branca, negra e amarela. No século seguinte, foram considerados também a forma e a estrutura dos seres como ferramentas para comprovar as diferenças entre as raças, ou seja, critérios morfológicos, como a forma do nariz, lábios, queixo, crânio passaram a discriminar racialmente a humanidade. Sendo assim, a base para a formulação das teorias que deram origem ao conceito de raças superiores e inferiores decorreu justamente da 
valorização das diferenças fenotípicas: "Existem raças puras, e, portanto distintas das outras: ou seja, há diferenças biológicas significativas entre os grupos e os indivíduos que os compõem" (MEMMI, 1993, p. 14). Esses argumentos serviram a teóricos como Gobineau (1816-1882) e Buckle (18211862), nomes fundamentais para o estabelecimento do pensamento racista, figuras que foram objeto de reflexão de Lima Barreto: "[a]té que ponto o livro do Conde Gobineau influiu no Darwin? Gobineau diz que Darwin e Buckle "criaram assim as principais derivações da nascente por mim aberta ${ }^{62} » "(D I, p$. 104 - Sem data, 1905, tradução de Ligia Ferreira). Interessa-nos sinalizar nessa passagem a atenção de Lima voltada para a obra de Gobineau, certamente de seu conhecimento ${ }^{63}$. Percebe-se claramente nesse excerto 0 contato de Lima com as teorias elaboradas por esses nomes incontornáveis - o naturalista Charles Darwin, o determinista geográfico Thomas Buckle, além do já mencionado Arthur de Gobineau. É digno de nota registrar que constava em sua biblioteca pessoal obras desses três teóricos: Origine des Espèces e Mi viaje alrededor del Mundo, de Darwin; Civilisation en Angleterre, de Buckle; além da Pléiade, de Gobineau. Esses volumes revelam não apenas o interesse do nosso autor carioca pela temática das teorias raciais, como evidenciam a atualidade desse debate no cenário brasileiro no início do século XX. Vale lembrar que, já em 1903 quando se propôs a estudar filosofia de modo autodidata, incluiu o "Estudo de raças" (DI, p. 36 - Sem data, 1903) no programa do curso por ele mesmo elaborado "segundo a história do

\footnotetext{
62 Lima Barreto citou Gobineau em francês: "ont créé ainsi les dérivations principales du ruisseau que j'ai ouvert »(DI, p. 104 - Sem data, 1905).

${ }_{63}$ Verificamos haver em meio aos manuscritos de Lima Barreto, que se encontram na Biblioteca Nacional do Rio de Janeiro, uma folha com dados biográficos de Gobineau (datas de nascimento e morte, cidade natal) além do registro bibliográfico da Pléiade desse autor; documento disponível em microfilme.
} 
pensamento filosófico, devendo cada época ser representada pela opinião dos seus mais notáveis filósofos" (DI, p. 35 - Sem data, 1903).

Observamos na nota penultimamente citada uma indagação de caráter investigativo "[a]té que ponto o livro do Conde Gobineau influiu no Darwin?", questão reveladora de que para Lima a obra de Darwin dialogava com pressupostos presentes na de Gobineau. À vista dessa hipótese, acreditamos ser imperativo examinarmos com certo vagar os escritos deste, a fim de seguirmos junto com Lima ao encalço dessa temática, uma vez que, em seguida, usou as palavras do próprio Gobineau, que se encontram no prefácio da obra Ensaio das desigualdades das raças humanas [Essai sur l'inégalité des races humaines] ${ }^{64}$ (GOBINEAU, 1976, p. 35), para completar essa entrada do diário.

Arthur de Gobineau foi um diplomata, escritor e filósofo francês que esteve no Brasil, de abril de 1869 a maio de 1870, chefiando a legação francesa. Escreveu o Ensaio ${ }^{65}$, obra monumental, composta por seis livros, o que contabiliza mais de 800 páginas. Publicada parcialmente em 1853, passados dois anos, uma edição completa veio a público (1855). Essa obra foi fundamental para difundir as ideias acerca da desigualdade entre os homens, pois postulava que as diferenças raciais configuravam-se em razão da

\footnotetext{
64 Do Ensaio, utilizamos uma edição digital preparada por Marcelle Bergeron, professora aposentada da École Dominique-Racine de Chicoutimi, do Québec. Disponível em: http://classiques.uqac.ca/classiques/gobineau/essai_inegalite_races/essai_inegalite_races.html Acesso em: 10 de novembro de 2011. Segundo Bergeron, essa edição foi realizada a partir do texto de Gobineau publicado pelas Éditions Pierre Belfond, 1967, 873 pages (Livres 1, 2, 3, 4 e 6). Para efeito didático, consideraremos os dados das Éditions Pierre Belfond quando nos referirmos ao Ensaio.

${ }^{65}$ Embora essa obra tenha sido concebida na França, foi na Alemanha que encontrou melhor acolhida. Aderiram ao assim chamado gobinismo o compositor alemão Richard Wagner (18131883), o filósofo Friedrich Nietzsche (1844-1900), o político inglês Houston Stewart Chamberlain (1855-1927) - genro de Wagner. Chamberlain, pautado nos postulados de Gobineau, sustentou em sua obra Os fundamentos do século XIX [The Foundations of the 19th Century] (1899) a superioridade da raça ariana.
} 
existência de diferentes raças, apostando na permanência dessas diferenças.

A permanência rigorosa, indelével dos traços e das formas, essa permanência que os mais longínquos documentos históricos afirmam e garantem, seria o carimbo, a confirmação dessa eterna separação das raças ${ }^{66}$ (Ibid., p. 138 , tradução nossa).

Nesse sentido, afirmava a supremacia da raça branca, considerada pura e, por isso mesmo, mais bela que as demais. Concepção que se deveu ao postulado de que as raças seriam desiguais em força e em beleza.

Já constatei que, de todos os grupos humanos, aqueles originários das nações europeias e dessa descendência são os mais belos. Para ser plenamente convencido disso, basta comparar os tipos variados espalhados pelo globo e vê-se que desde a construção e a face, de certa forma, rudimentar do Pélagien e do Pécherai até o tamanho elevado, as nobres proporções de Charlemagne, até a inteligência regular dos traços de Napoleão, até a imponente majestade notada na face real de Luis XIV, há uma série de gradações pela qual os povos que não são do sangue dos brancos aproximam-se da beleza, porém não a atingem ${ }^{67}$ (Ibid., p. 146, tradução nossa).

Certo de que as raças eram, de fato, desiguais, Gobineau buscou responder se elas seriam dotadas da capacidade de igualarem-se umas às outras: "Essa pergunta diz respeito, na verdade, à perfectibilidade indefinida da espécie e à igualdade entre as raças. Sobre os dois pontos, respondo não ${ }^{68,}$ (Ibid., p. 149, tradução nossa). Eis aí nessa assertiva negativa sua resposta.

66 Texto original: «La permanence rigoureuse, indélébile des traits et des formes, cette permanence que les plus lointains documents historiques affirment et garantissent, serait le cachet, la confirmation de cette éternelle séparation des races » (Ibid., p. 138).

${ }^{67}$ Texto original: «J'ai déjà constaté que, de tous les groupes humains, ceux qui appartiennent aux nations européennes et à leur descendance sont les plus beaux. Pour en être pleinement convaincu, il suffit de comparer les types variés répandus sur le globe, et l'on voit que depuis la construction et le visage, en quelque sorte, rudimentaire du Pélagien et du Pécherai jusqu'à la taille élevée, aux nobles proportions de Charlemagne, jusqu'à l'intelligente régularité des traits de Napoléon, jusqu'à l'imposante majesté qui respire sur le visage royal de Louis XIV, il y a une série de gradations par laquelle les peuples qui ne sont pas du sang des blancs approchent de la beauté, mais ne l'atteignent pas » (Ibid., p. 146).

${ }^{68}$ Texto original: «Cette question est, au fond, celle de la perfectibilité indéfinie de l'espèce et de l'égalité des races entre elles. Sur les deux points, je réponds non » (Ibid., p. 149). 
Via o cruzamento interracial como um erro, pois a miscigenação significaria degeneração não só racial, mas também social. Seguiu, pois, demonstrando a desigualdade intelectual das raças. No que concernem as implicações quanto à inteligência, discorreu do seguinte modo:

\begin{abstract}
Quando a história estabelece tão claramente esse irreconciliável antagonismo entre as raças e seus modos de cultura, fica bem evidente que a diferença e a desigualdade residem no fundo dessas repugnâncias constitutivas e, do momento em que o Europeu não pode esperar civilizar o negro, e que ele consegue transmitir ao mulato apenas um fragmento de suas aptidões; que esse mulato, por sua vez, unido ao sangue dos brancos, não originará ainda indivíduos perfeitamente aptos a compreender algo melhor que uma cultura mestiça de grau mais avançado em direção às ideias da raça branca, autoriza-me a estabelecer a desigualdade das inteligências nas diferentes raças ${ }^{69}$ (Ibid., p. 167, tradução nossa).
\end{abstract}

A perspectiva aqui adotada evidencia o caráter pessimista previsto por

Gobineau no que dizia respeito aos não brancos, ou seja, aos negros e mestiços, condenados a jamais alcançarem o nível de intelecto dos brancos.

Diante de todos esses postulados podemos imaginar 0 quanto desagradou-Ihe a notícia de sua nomeação para o Brasil, contudo, não pôde declinar da indicação, pois já o havia feito em ocasião anterior quando fora nomeado à China (RAEDERS, 1996, p. 9-10). Sendo assim, Gobineau deixou Atenas, último posto ocupado antes de vir para nosso país, em setembro de

\footnotetext{
${ }^{69}$ Texto original: «Quand l'histoire établit si nettement cet irréconciliable antagonisme entre les races et leurs modes de culture, il est bien évident que la dissemblance et l'inégalité résident au fond de ces répugnances constitutives, et du moment que l'Européen ne peut pas espérer de civiliser le nègre, et qu'il ne réussit à transmettre au mulâtre qu'un fragment de ses aptitudes ; que ce mulâtre, à son tour, uni au sang des blancs, ne créera pas encore des individus parfaitement aptes à comprendre quelque chose de mieux qu'une culture métisse d'un degré plus avancé vers les idées de la race blanche, je suis autorisé à établir l'inégalité des intelligences chez les différentes races » (Ibid., p. 167).
} 
1868, dirigindo-se a Paris, onde tentou de todas as maneiras mudar sua destinação. Não conseguiu, veio sozinho para a América, intentando aqui permanecer o menos possível. A contragosto, embarcou em Bordeaux "às 4 horas da tarde da quinta-feira, 15 de fevereiro de 1869, em companhia de seu fiel camareiro Honoré e de um secretário da Legação que ia para seu primeiro posto, o visconde de La Marlière" (Ibid., p. 13).

Ao chegar à costa brasileira, Gobineau decidiu não descer em Pernambuco, pois observara as péssimas condições do ancoradouro, agradouIhe, porém, a bela paisagem. Diferentemente, ao aportar em Salvador, adiantou-se logo em descer. Registrou aí o aspecto que mais lhe chamou a atenção - a quantidade de negros, de todos os matizes.

No Rio de Janeiro, seu destino final, comprouve-se em saber que no dia seguinte o Imperador desejava recebê-lo. Se por um lado, nascia daí uma simpatia recíproca e sólida amizade, cultivada nas longas conversas semanais mantidas entre ambos; por outro, Gobineau não cessava de assinalar seu descontentamento pelo clima e fauna brasileira, destacando o caráter selvagem de nosso país, aspecto observado a partir de uma perspectiva negativa - "[o]s insetos e os bichos desagradáveis pulula[va]m neste país no qual Gobineau obstina[va]-se em nada encontrar de seu agrado", sublinhou Raeders (Ibid., p. 21).

Descreveu a situação racial brasileira do seguinte modo: "[t]rata-se de uma população totalmente mulata, viciada no sangue e no espírito e assutadoramente feia" (Id., 1988, p. 96). Sob esse prisma, o mulato era visto como inviável para o desenvolvimento da nação. Estimava que em 200 anos a 
população brasileira desaparecesse. Ainda de acordo com esse teórico, uma saída para os males étnicos de nosso país estaria na imigração europeia.

\begin{abstract}
Mas, se em lugar de se reproduzir por ela mesma, a população brasileira estivesse em situação de minorar com vantagem os elementos desgraçados de sua constituição étnica atual, fortificando-os por alianças de valor mais alto com raças europeias, então o movimento de destruição observado em suas classes cessaria e daria lugar a um curso totalmente oposto. A raça se levantaria, a saúde pública melhoraria, o temperamento moral se veria recuperado e as modificações mais felizes se introduziriam no estado social [d]este admirável país (GOBINEAU apud PETRUCCELLI, 1996, p. 138).
\end{abstract}

Dito de outro modo, a alternativa para remediar nossos males seria injetar sangue branco por meio dos cruzamentos interraciais, na tentativa de abrandar a potencialidade dos estigmas das raças ditas inferiores.

Observados os postulados básicos do gobinismo, convêm abordar, não com o mesmo vagar, os estudos de Darwin e Buckle. A origem das espécies [Origin of species] (1859), a mais conhecida obra de Darwin, publicada passados quatro anos da publicação do Ensaio, teve sua primeira edição intitulada Sobre a Origem das Espécies por Meio da Seleção Natural ou a Preservação de Raças Favorecidas na Luta pela Vida [On the Origin of Species by Means of Natural Selection, or the Preservation of Favoured Races in the Struggle for Life]. Em linhas gerais, mostrava que os seres humanos tiveram um antepassado comum, sendo que ao longo do tempo houve um processo de mudanças climáticas, em decorrência do qual sobreviveram aqueles que se desenvolveram e se adaptaram a tais mudanças. A esse processo deu-se 0 nome de seleção natural, ou seja, diz respeito aos organismos vivos que passaram por mutações genéticas a fim de resistirem às mudanças. Na luta pela vida os melhores seres vivos sobreviveram. Foi essa teoria que deu 
origem ao darwinismo social, difundida em razão de interesses políticos ${ }^{70}$. Houve, pois, uma transposição do conceito biológico para o âmbito social. Dirão que a melhor política social é aquela que acompanha as leis da natureza a fim de legitimar ideologicamente as políticas de exploração dos considerados menos perfectíveis.

Já Buckle ficou conhecido como representante do determinismo geográfico, atentava para as condições climáticas, para a vegetação e o solo a fim de classificar determinado país e, por extensão, seu povo. Desse modo, para ele, o desenvolvimento de uma nação estava condicionado ao meio físico: "[b]asicamente, o que se propunha era vincular o desenvolvimento das civilizações a alguns fatores como calor, umidade, fertilidade da terra, sistema fluvial" (ORTIZ, op. cit., p. 17). O quesito meio fundamenta aqui o discurso científico desse teórico.

Até meados do século XIX, acreditava-se na origem comum da humanidade, sendo que as diferenças entre os humanos seriam resultado de um maior ou menor grau de degeneração ou de perfectibilidade, visão essa conhecida como monogenista, crença de que todas as raças teriam derivado de um único tipo primitivo. Posteriormente, surgiu a hipótese poligenista que postulava que as diferenças raciais configuravam-se em razão da existência de diferentes raças, negando, portanto, a origem comum da humanidade. Nesse sentido, os poligenistas enalteciam as raças puras e consideravam o cruzamento interracial um erro, pois a miscigenação resultaria em degeneração racial e social. Tendo em vista esses postulados sobre a origem da

\footnotetext{
${ }^{70}$ Destacamos o expansionismo inglês no bojo da Revolução Industrial em direção à África e Índia com o intuito de explorar e dominar esses territórios e povos.
} 
humanidade, podemos aproximar Darwin da visão monogenista e Gobineau, diferentemente, da poligenista.

À luz das teorias formuladas por Darwin, Buckle e Gobineau, são dignas de nota algumas passagens do Diário, ilustrativas do modo como Lima as recebeu.

\begin{abstract}
Vai se estendendo, pelo mundo, a noção de que há umas certas raças superiores e umas outras inferiores, e que essa inferioridade, longe de ser transitória, é eterna e intrínseca à própria estrutura da raça. Diz-se ainda mais: que as misturas entre essas raças são um vício social, uma praga e não sei que cousa feia mais (DI, p. 110 - Sem data, 1905).
\end{abstract}

Ora, aqui Lima parece dialogar estreitamente com as ideias de Gobineau que negava a origem comum da humanidade, postulando a existência de raças separadas, identificado, pois, à visão poligenista. Essa visão foi considerada por Gould (1999) uma "linha dura" em oposição à "linha branda", ou seja, monogenista que, embora não discordasse da inferioridade atribuída aos negros, acreditava na origem única dos homens.

O argumento "duro" prescindiu da versão bíblica por considerála alegórica, e afirmou que as raças humanas eram espécies biológicas separadas e descendiam de mais de um Adão. Como os negros constituíam mais de uma forma de vida, não participavam da "igualdade do homem". Os proponentes deste argumento foram chamados "poligenistas" (GOULD, 1999, p. 26).

Retornando ao Diário, acompanhemos um comentário de Lima ainda mais explícito acerca dessas teorias, elaborado segundo a visada teórica dos estudos antropométricos:

Os séculos que passaram não tiveram opinião diversa a nosso respeito - é verdade; mas, desprovida de qualquer 
base séria, as suas sentenças não ofereciam o mínimo perigo. Era o preconceito; hoje é o conceito. Esmagadoras provas experimentais endossam-no. Se F. tem 0,02 m a mais no eixo maior da oval de sua cabeça, não é inferior em relação a $B$, que tem menos, porque ambos são da mesma raça; contudo, em se tratando de raças diferentes, estão aí um critério de superioridade. As mensurações mais idiotas são feitas, e, pelo complacente critério do sistema métrico, os grandes sábios estabelecem superioridades e inferioridades. Não contentes com isso, buscam outros dados, de touristes imbecis e de aventureiros da mais baixa honestidade (DI, p. 111 - Sem data, 1905).

Ao longo da curta existência de Lima, as pesquisas científicas contemplaram a vertente dos estudos anatômicos e craniométricos desenvolvidos na Europa, especialmente pela Sociedade Antropológica de Paris fundada em 1859 pelo poligenista Paul Broca (1824-1880). O objetivo desses estudos era o de justificar as diferenças entre os homens. De acordo com Broca, "as diversidades humanas observáveis eram um produto direto das diferenças na estrutura racial" (Apud SCHWARCZ, 1993, p. 54). E para postular tais diferenças, os estudos pautavam-se na análise do crânio dos indivíduos a fim de "comprovar a interrelação entre inferioridade física e mental" (Ibid., p. 54). As medições esforçavam-se para comprovar que o cérebro dos brancos era maior que o dos negros, de forma a estabelecer uma hierarquia de valor intelectual.

Começando pelas conclusões, Broca chegava às crenças compartilhadas pela maioria dos indivíduos brancos do sexo masculino que triunfaram em sua época: por graça da natureza, estes ocupavam a posição mais elevada, enquanto que as mulheres, os negros e os pobres figuravam em posição inferior (GOULD, op. cit., p. 78).

Nesse contexto, destacamos a Antropometria - campo de investigação 
antropológica que compreendia a Frenologia e a Craniometria ${ }^{71}$. Em suma, tendo como ponto de partida a observação dos comportamentos humanos, essas vertentes científicas atribuíam a capacidade humana ao tamanho e proporções do cérebro dos diferentes povos ${ }^{72}$. Nesse bojo, reveste-se de especial significado os comentários de Lima acerca das mensurações cranianas, temática de constante reflexão pessoal: "Se a feição, o peso, a forma do crânio nada denota quanto a inteligência e vigor mental entre indivíduos da raça branca, porque excomungará o negro?” (DI, p. 61- Sem data, 1904), questionava-se ele aos vinte e três anos de idade. Aqui, o jovem Lima faz uma referência expressa aos estudos ligados à Antropometria, indagando-se sobre a validade desses dogmas científicos. Observe-se, nesse sentido, a clareza conceitual de Lima, quando diz: "[a] capacidade mental dos negros é discutida a priori e a dos brancos a posteriori" (DI, p. 61- Sem data, 1904). Sabia bem das implicações no campo das relações sociais no tocante ao tratamento conferido a uns e outros.

Assim, "[t]er a pele clara, provir do 'sangue' europeu, não ter mesclas

\footnotetext{
${ }^{71}$ Segundo o dicionário Houaiss (2003), esses termos são definidos do seguinte modo: Antropometria: 1. ANTROPOL parte da antropologia que trata da mensuração do corpo humano ou das suas partes; somatometria 2. registro das particularidades físicas dos indivíduos 3. p. ext. técnica de identificação de indivíduos; esp. criminosos, com base na descrição do corpo humano (fotografias, medidas, impressões digitais, etc) 4. p. ext serviço encarregado da antropometria.

Frenologia: MED doutrina segundo a qual cada faculdade mental localiza-se numa parte do córtex cerebral e o tamanho de cada parte é diretamente proporcional ao desenvolvimento da faculdade correspondente, sendo este tamanho indicado pela configuração externa do crânio. Craniometria: ANTROPOL mensuração, medição do crânio; estudo das características métricas de um crânio.

72 Destacamos, nesse campo, os estudos do médico sueco Anders Ratzius (1796-1860) que desenvolveu a Craniologia técnica, cujo objetivo era o de medir o índice cefálico para classificar os grupos humanos e do médico italiano Cesare Lombroso (1835-1909) consagrado pela obra O Homem Delinquente [L'uomo delinquente] (1876), na qual sustentava que a criminalidade era algo físico e hereditário, assim era possível prever o criminoso pela medida do crânio. $\mathrm{Na}$ linha desses estudos, no Brasil, sublinhamos a atuação do médico e etnólogo baiano Nina Rodrigues (1862-1906) professor de medicina legal na Faculdade de Medicina da Bahia de 1891 a 1906, autor das obras Mestiçagem, degenerescência e crime (1889), As raças humanas e a responsabilidade penal no Brasil (1894), dentre outras.
} 
com as raças 'inferiores', principalmente a negra, constituía, segundo as idéias da época, o distintivo da nobreza, da superioridade social e moral" (MUNANGA, 2008, p. 63); esses eram os requisitos para ser reconhecido intelectual e moralmente à época. Tais requisitos, sem dúvida, tocavam a "tecla sensível" (DI, p. 46 - 06 de novembro de 1904) de Lima Barreto - a origem racial. Nesse momento, um negro que ousasse aventurar-se como escritor, ofício reconhecidamente dos brancos, conforme assinalou Silva (2005, p. 55), "será encarado como alguém investido de uma pressuposta inferioridade". Não à-toa, a Lima ofereceram o desprezo intelectual que, além de afastá-lo das glórias almejadas, ainda o levou à desgraça pessoal. Em seu trabalho, Silva (Id.) discutiu a postura adotada pelas elites perante a produção intelectual de um escritor negro ou mestiço, apontando o perigo de se reconhecer a capacidade desses tipos tomados como inferiores.

Se escrever, no período considerado, é um ato intelectual dos mais admirados, como compreender que um ser inferior seja capaz de realizá-lo? Vai-se à obra, na expectativa de lá encontrar as marcas de inferioridade, do atavismo que não permite o escape do que determina a natureza humana para além dos saberes que se possa adquirir. Mas, se pelo contrário ela se demonstrar pouco apropriada, quanto ao significado, há que se buscar a inferioridade nos meandros do estilo. E ainda, se o negro e o mestiço são seres destinados a desaparecer para o bem da nação, como aceitar que apareça como literato? Considerá-lo uma exceção, contudo, pode ser uma forma de confirmar a regra. Entretanto, se tal exceção, além de dificultar com seu discurso o encontro dos indícios de sua inferioridade, atentar contra a tese dominante da hierarquização racial, ter-seá que converter esse espírito rebelde em um caso de patologia. Pois, ao oprimido, a aceitação de que é inferior "naturalmente" pode assegurar-Ihe uma tolerância adicional, desde que saiba comportar-se enquanto ausência, e não presença, naquilo que produz. Pois o inverso significará que está propondo ser a realidade outra e não aquela proposta pela visão dominante (Ibid., p. 55). 
as teorias formuladas pelo cientificismo europeu, fato incontestável no período pela posição privilegiada que os colonizadores assumiram enquanto detentores da capacidade civilizadora dos povos. Reforçam essa reflexão as palavras do poeta Cruz e Sousa (1861-1898), que enxergou a fatalidade decorrente de sua condição racial.

\begin{abstract}
Nos países novos, nas terras ainda sem tipo étnico absolutamente definido, onde o sentimento da Arte é silvícola, local, banalizado, deve ser espantoso, estupendo o esforço, a batalha formidável de um temperamento fatalizado pelo sangue e que traz consigo, além da condição inviável do meio, a qualidade fisiológica de pertencer, de proceder de uma raça que a ditadora ciência d'hipóteses negou em absoluto para as funções do Entendimento e, principalmente, do entendimento artístico da palavra escrita (CRUZ E SOUSA, 2008, p. 625) ${ }^{73}$.
\end{abstract}

A essa voz, somamos a de Luiz Gama, cujos versos também denunciaram o lugar relegado ao negro:

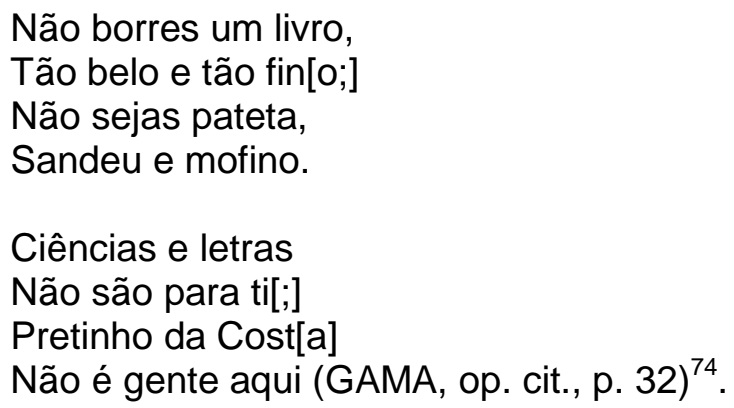

A possibilidade de ascensão para um autor negro ou mulato, segundo Bosi (2002, p. 188), dependia da combinação "de talento pessoal e apadrinhamento sustentado no momento oportuno". E citou alguns exemplos que deram certo: Luiz Gama, Machado de Assis, André Rebouças e José do

\footnotetext{
${ }^{73}$ Trecho extraído do texto "Emparedado", contido no livro Evocações, publicado em 1898, logo após a morte do autor. Vale mencionar que essa obra constava na "Coleção Limana" (BARBOSA, op. cit., p. 392).

${ }^{74}$ Trecho extraído do poema "No Álbum do meu amigo J. A. da Silva Sobral".
} 
Patrocínio. O caso de Lima, Bosi classificou como "o drama da subida precocemente interrompida", completou dizendo:

Ingressando na vida adulta, o jovem promissor se vê desamparado dos primeiros apoios e cai na esfera competitiva de um meio onde vicejam a hostilidade ou o desprezo pelo pobre e, em particular, pelo negro ou mestiço (Ibid., p. 188).

A verdade é que Lima nunca manteve relação afetiva com o padrinho Afonso Celso de Assis Figueiredo (1836-1912), mais conhecido pelo epíteto de Visconde de Ouro Preto, importante político do Segundo Império, que custeou seus primeiros estudos. Rompeu logo cedo com ele magoado pelo fato do padrinho nunca ter the dedicado um gesto de carinho: "[r]essentido, o afilhado passou a evitar a presença antipática, que só Ihe fazia avivar a situação humilhante de protegido. Isto aconteceu em 1902 ou 1903" (BARBOSA, op. cit., p. 120). Lima não se mostrou disposto a participar desse jogo social de relações de compadrio, certamente sabia das amarras às quais seria acorrentado, caso se servisse dos favores do abastado padrinho. Em 1903, ao referir-se a um auxílio financeiro que seria concedido pelo Visconde, expandiuse do seguinte modo: "E os dez mil-réis do tal visconde! Idiota. Os protetores são os piores tiranos" (DI, p. $34-12$ de junho de 1903). A força contida nessa última afirmação lapidar não deixa dúvida da postura desse autor carioca no tocante à autonomia subjugada.

Movidos pelo ímpeto de buscar compreender os mecanismos encontrados pela elite para afastar os negros dos centros de poder, vejamos, a partir da perspectiva limabarretiana, os desdobramentos das teorias raciais que aguilhoaram sua trajetória e de outros dos seus. 


\subsection{O Aguilhoar das Teorias Raciais na Trajetória de Lima Barreto}

Um dos resultados dessas teorias raciais no cenário brasileiro foi a ideologia do branqueamento que previa uma miscigenação controlada (mestiços cruzando com brancos); incutida de modo incontestável a superioridade da raça branca. Considerando a realidade de um país, cuja nação era formada por grande parte de negros a saída foi optar pelo cruzamento interracial a fim de tentar extinguir os caracteres das raças inferiores. A fusão das raças levaria à fusão cultural, ou seja, a imagem do brasileiro se faria a partir da incorporação das culturas europeia, indígena e africana. Porém, muitos daqueles formados por essa mistura ficaram à margem da sociedade, impedidos de ascender socialmente justamente por trazer consigo o caráter mestiço.

A intervenção de João Batista de Lacerda (1846-1915), médico e cientista brasileiro, então diretor do Museu Nacional do Rio de Janeiro, no Primeiro Congresso Universal das Raças ${ }^{75}$ realizado em Londres em 1911, oficializou uma opção brasileira pelo ideal de branqueamento. Vale acompanhar nas palavras do nosso representante, as previsões candentes no horizonte nacional:

A seleção sexual continua, aperfeiçoando-se sempre ao subjugar o atavismo e ao purgar os descendentes dos mestiços de todos os traços característicos dos negros. Graças a esse procedimento de redução étnica, é lógico supor que, no espaço de um novo século, os mestiços desaparecerão do Brasil, fato que coincidirá com a extinção paralela da raça negra entre nós (LACERDA, 1911, [s.d.t.]).

${ }^{75}$ É digno de nota informar que constava na quarta estante da terceira prateleira da "Coleção Limana", a seguinte referência: "567 - Congresso Universal das Raças. J. B. de Lacerda" (BARBOSA, op. cit., p. 394). 
Lacerda enfatizou as mudanças pelas quais passaria a população mestiça brasileira em virtude das correntes de imigração europeia que corroborariam para o aumento dos caracteres brancos, de acordo, portanto, com a saída sugerida por Gobineau.

A substancial presença dos mestiços entre nós revestiu-se de essencial importância dado a quantidade elevada desses tipos, por isso mesmo Lacerda precisou enfrentar esse fato. Buscando demonstrar que o Brasil daria certo, partiu do seguinte questionamento: brancos e negros seriam duas raças ou duas espécies? Nesse momento, o critério científico usado para distinguir raça de espécie era o da fecundidade. Respondeu a essa questão do seguinte modo: "se seus descendentes continuam a se reproduzir seus reprodutores constituem uma raça, se ao contrário esses descendentes tornam-se estéreis, seus reprodutores que efetuaram o cruzamento constituem uma espécie" (Ibid.). Baseando-se nesse critério, Lacerda concluiu que brancos e negros constituíam duas raças, visto que seus descendentes eram fecundos. Para ele, os mestiços não apresentavam características fixas, por isso não formavam uma raça, uma vez que sujeitos a variação a cada novo cruzamento, ora tendiam ao tipo branco, ora ao negro. Ainda segundo nosso representante, as populações brasileiras tendiam ao tipo branco em razão dos cruzamentos dos mestiços com os brancos.

Defendeu, portanto, a superioridade do ser mestiço, sinalizando que 0 cruzamento deste com o branco levaria à extinção da raça negra e do próprio mestiço, visto que em três gerações de cruzamento (mestiço x branco) chegarse-ia ao tipo branco. Daí o incentivo à imigração europeia. Nesse cenário, os 
mestiços eram vistos como mais ativos e inteligentes; havendo para eles a possibilidade de ascensão. Considerou nefasta a imigração dos africanos para - Brasil, o que levou a resultados étnicos desastrosos. Previu ainda o desaparecimento do índio, do gaúcho, do caboclo e do jagunço - tipos perfeitamente adaptados às condições do meio onde viviam, sendo assim não resistiriam à chegada da civilização - máquinas, tecnologia que modificariam esse ambiente. Embora as conclusões de Lacerda fossem mais ou menos otimistas para a mentalidade então vigente, mostrando que nosso país caminhava rumo ao branqueamento, suas ideias não foram bem recebidas em âmbito nacional, pois os críticos viram que seria preciso muito tempo para que o Brasil se tornasse um país branco.

Ao examinar os argumentos sustentados por Lacerda nesse congresso, Seyferth ([s.d.t.]) concluiu:

\begin{abstract}
A tese do branqueamento reflete a preocupação de parte da elite republicana do início do século com o problema da mestiçagem e seu significado no contexto mais amplo da história do Brasil. Mais do que isto, porém ela se afirmou como solução ideal e tipicamente brasileira para a questão racial. Apesar de João Batista de Lacerda não ser o autor mais exemplar dessa corrente de pensamento (racista), é representativo da versão mais otimista e concedeu à tese uma legitimidade antropológica que, na sua interpretação das discussões havidas no Congresso das Raças, foi plenamente aceita naquele plenário (Ibid.).
\end{abstract}

É inegável a importância dos mestiços nesse cenário, tomados como meio para se alcançar o tipo branco, saída tortuosa rumo ao branqueamento. Acompanhando essa toada, seguiu Romero (op. cit.):

A minha tese, pois, é que a vitória na luta pela vida, entre nós, pertencerá no porvir, ao branco; mas que este, para essa mesma vitória, atento as agruras do clima, tem necessidade de 
aproveitar-se do que de útil as outras duas raças the podem fornecer, máxime a preta, com que tem mais cruzado. Pela seleção natural, todavia, depois de prestado o auxílio de que necessita, o tipo branco irá tomando preponderância até mostrar-se puro e belo como no Velho Mundo. Será quando já estiver de todo aclimatado no continente. Dois fatos contribuirão largamente para tal resultado: - de um lado a extinção do tráfico africano e o desaparecimento constante dos índios, e de outro a emigração europeia (lbid., p. 58).

Esse panorama das teorias raciais dimensiona 0 peso desses postulados científicos no Brasil e, por conseguinte, na vida de Lima Barreto que, por ser mestiço, já nasceu marcado pelo signo da inferioridade racial. Em nota de uma impressão de leitura, é possível observarmos a reação de Lima diante de tais conclusões pessimistas:

Quando há dias li numa das histórias do Brasil do Senhor João Ribeiro, pág. 234: «Não podemos pensar que o homem de cor, consequência semi-híbrida do contato heterogêneo de raças tão distanciadas que, até por eminentes cientistas como Haeckel, são consideradas como espécies diversas, seja a peste da cultura americana, como sentenciam os sociólogos ${ }^{76}$, ri-me com uma espontaneidade, que eu até mesmo me admirei (DI, p. 112 - Sem data, 1905).

Nessa que se trata de uma das únicas passagens em que Lima encara essa temática de modo aparentemente leve, a ponto de gozar do comentário tecido por João Ribeiro, ressaltamos as ideias que moviam o debate entre os intelectuais à época - a sentença condenatória para os "homens de cor". No Diário, essa temática racial pode ser apreendida a partir de diferentes ângulos, seja por meio dos comentários alusivos diretamente ao teor das teorias raciais, tais como explicitamos nas páginas precedentes; seja pelo testemunho pessoal de Lima ao relatar ocasiões em que se viu ou vira outros de seus pares

\footnotetext{
${ }^{76}$ As aspas («») foram colocadas por Lima Barreto. Referência à obra História do Brasil, publicada, em 1901, pelo historiador brasileiro João Ribeiro (1860-1934), membro da Academia Brasileira de Letras.
} 
violentamente atingidos pelas crenças difundidas sobre raça ou ainda por meio das notas reveladoras de certa ambivalência quanto à crença na ciência. $O$ olhar atento sobre essas notas íntimas acerca de raça nos possibilitou visualizar um trânsito triangular da parte de Lima que se moveu da esfera familiar para o espaço privado do diário e deste para a arena pública - a sociedade, trazendo consigo para as páginas íntimas questionamentos e experiências subjetivas referentes à condição racial.

Interessa-nos, nesse momento, especular como Lima marcou no espaço privado do diário sua passagem pelo espaço público. Vejamos, nessa perspectiva, um relato:

Fui a bordo ver a esquadra partir. Multidão. Contato pleno com meninas aristocráticas. Na prancha, ao embarcar, a ninguém pediam convite; mas a mim pediram. Aborreci-me. Encontrei Juca Floresta. Fiquei tomando cerveja na barca e saltei.

É triste não ser branco (DI, p. 130 - 24 de janeiro de 1908, grifos nossos).

Conta nessa ocasião ter recebido convite para ir ver a saída de uma esquadra, depois de muito hesitar, aceitou. A nosso ver, Lima já se mostrara receoso diante de tal convite por desconfiar do tratamento que poderia receber nesse ambiente aristocrático. A restrição por ele sofrida encerra-se na conjunção sublinhada, que demonstra a diferença no modo de haver-se com ele. A última frase dessa nota revela a compreensão desse episódio por parte de nosso autor, o aborrecimento deveu-se a sua cor. Parece-nos que o sentimento de tristeza expresso por não figurar como branco no espaço público poderia apenas ser expandido no âmbito confessional das páginas íntimas, espaço onde pôde deixar correr para fora suas percepções mais particulares. Ora, declarar ser triste não ser branco pode exprimir de imediato o lamento por 
ser negro ou ainda, em uma perspectiva mais aguda, a faculdade de compreender os significados sociais no tocante ao quesito racial da conformação da ordem hierárquica estabelecida por aqueles considerados superiores, justamente por filiarem-se à raça branca, condição legitimadora do domínio e privilégios gozados por esses em oposição à subalternidade e desprezo imputada às raças não brancas.

Nas consciências tanto de brancos quanto de negros intelectualizados pairavam os estigmas propagados pela ciência, nesse sentido, acompanhamos o olhar analítico de Lima ser igualmente pautado pela ótica racial, mesmo ao comentar situações triviais.

No bonde, na altura da Rua dos Voluntários, tomaram-no dois rapazes e uma rapariga. A rapariga sentou-se ao meu lado. Como era de meu dever, comecei a observar-lhe discretamente. Ela não se aborreceu e observou-me. Estendeu a mão, mirei-lhe a mão com amor e firmeza. Ela escondia. Eu fingia olhar para o outro lado, ela estendia, eu olhava. E assim fomos até o Leme. Era uma espécie de galanteio que eu tinha inventado e que agradara a italiana (falava em patoá italiota com os rapazes). Já nas curvas, ela avançava mais do que eu. Dava-se encontrões. Preparei o flirt para o botequim, mas, aí chegando, o cioso irmão, percebendo, levou-a para longe. A minha covardia não permitiu que a seguisse, nem que a esperasse, de volta. Com isso, eu adquiri uma certeza; embora mulato, os meus olhares podem interessar as damas e desconfiar os irmãos delas (DI, p. 72-73 - 01 de janeiro de 1905, grifos nossos).

Embarcamos aqui juntamente com Lima acompanhando, por meio das descrições, os personagens figurantes nessa cena, dos quais sabemos as origens, são italianos, provavelmente brancos. Esse dado é fundamental para o contraste construído textualmente no que concerne à condição mestiça de nosso autor. Uma vez mais, faz uso de uma conjunção concessiva, no caso embora, para deduzir suas conclusões após o flirt esboçado: apesar de mulato, 
despertava a atenção das moças brancas e a desconfiança dos irmãos dessas. Ou seja, as suspeitas dos irmãos se dariam também em razão de sua cor. $O$ fato de ser mulato pareceu orientar sempre as reflexões de Lima, sobre seu olhar incorreu essencialmente o quesito racial. Ainda versando a respeito de paqueras, expandiu-se ele: "A francesa de defronte à botica continua a me interessar. É Louise Léon, costureira. Magra e alourada e eu... Afonso! Afonso!" (DI, p. 95 - 30 de janeiro de 1905). A caracterização dessa moça francesa alourada suscita, desde logo, o traço da brancura como algo passível de interesse desse tímido conquistador, que apenas ensaia dar vazão às ideias sentimentais, visto o pensamento ser suspenso pelas reticências, que poderiam talvez dar lugar à seguinte continuidade: "e eu mulato". Hipótese, a nosso ver, plausível, dado a ótica racial nortear o ponto de vista limabarretiano no espaço das notas íntimas, seja ao relatar experiências de caráter mais ordinário ou mais austero.

Hoje, à noite, recebi um cartão-postal. Há nele um macaco com uma alusão a mim e, embaixo, com falta de sintaxe, há o seguinte:

"Néscios e burlescos serão aqueles que procuram acercar-se de prerrogativas que não tem. M"

O curioso é que o cartão em si mesmo não me aborrece; o que me aborrece é lobrigar se, de alguma maneira, o imbecil que tal escreveu tem razão.

"Prerrogativas que não tenho"...

Ah! Afonso! Não te dizia ...

Desgosto! Desgosto que me fará grande (DI, p. $88-17$ de janeiro de 1905, itálicos do autor, grifos nossos).

Sabemos das associações discriminatórias estabelecidas entre 0 macaco e os descendentes da raça negra que figuram no imaginário coletivo ${ }^{77}$.

\footnotetext{
77 Investigações científicas acerca da origem biológica dos negros cogitavam serem eles originários do cruzamento do branco com o macaco, a exemplo da demonstração proposta pelo médico dinamarquês Johann Fabricius (1745-1808), aluno de Lineu (1707-1778),
} 
Esse cartão corporifica uma situação que hoje poderia ser notadamente avaliada como um preconceito de ordem étnica. Contudo, esclarecemos não ser nossa intenção percorrer os conceitos de racismo ${ }^{78}$ e preconceito, mas sim avaliar as considerações de Lima suscitadas pela inscrição no cartão. Essa inscrição convida-nos a investigar o que seriam as tais prerrogativas referidas, palavra ruminada no pensamento de Lima, de modo que a repetição deixa entrever. O significado literal do aludido vocábulo diz respeito a vantagens ou privilégios inerentes a um cargo ou profissão, nesse sentido, o remetente desse comentário classificou seu destinatário como néscio e burlesco, ou seja, ignorante e ridículo, por intentar abeira-se de direitos especiais que não possuía. E a razão por não possuí-los estaria justamente no paralelo estabelecido entre o macaco e o destinatário. Convém lembrar ter sido a partir de 1905 que Lima passou a trabalhar como jornalista profissional, escrevendo

considerado o fundador da história natural moderna (POLIAKOV, 1975, p. 172). Ilustra a disseminação das teorias científicas em lugares comuns, o poema abaixo, publicado na seção "Jóias e Bugigangas" (seção de humor, piadas, textos diversos, etc) do jornal O Estado de S. Paulo, na terça-feira, 22 de janeiro de 1895 (compilado por Fabiana Carelli, mantida a grafia original):

\section{Scintillas}

(Filindal)

Se o corpo humano - ensina a biologia -

Quatorze corpos simples o compoem...

Ó minha formosissima Maria,

Deixa o bordado, e em mim teus olhos põe.

Se é verdade o que a chimica revela

Da sciencia pelos positivos meios,

Porque has de tu, Maria, ser tão bella,

E eu e o parente chimpanzé, tão feios?

É porque a Fórma é tudo, essencialmente

Somos, querida, todos nós eguaes

Tu és bella: e o chimpanzé, tão repelente,

É o ancestral, diz Darwin, de teus paes."

${ }^{78}$ Segundo Wieviorka (2007, p. 17), o termo racismo apareceu no período entre as duas grandes guerras, ingressando no dicionário Larousse em 1932. Chama a atenção para a anterioridade das práticas racistas que antecederam a nomeação do conceito. 
uma série de reportagens para o jornal Correio da Manhã, sob o título: "Os subterrâneos do morro do castelo". Tendo essa notícia biográfica em vista, é possível deduzir que o remetente desejava privar Lima Barreto das vantagens concedidas pelo status de jornalista, ecoando daí a impossibilidade de reconhecimento intelectual daqueles marcados pelos estigmas raciais, conforme já comentamos. Digno da atenção de nosso autor foi enxergar a possibilidade desse remetente estar certo naquilo que apontou. Questionamento resultante das repetidas vezes em que fora tomado na conta de mulato, observadas as implicações sociais dessa condição.

Cabe aqui assinalar o significado do vocábulo 'mulato', originário do termo 'mulo' (1525), de acordo com o dicionário Houaiss (2003) é o mesmo que ‘jumento' e, na linguagem informal, refere-se a "indivíduo cheio de manhas, inzoneiro, sonso", além de dizer respeito a "que ou aquele que é filho de pai branco e de mãe negra (ou vice-versa)" ou "que ou aquele que apresenta traços das raças negra e branca"79. Ressaltamos ainda o debate sobre a esterilidade do mulato, visto seus genitores pertencerem a raças distintas (POLIAKOV, op. cit., p. 174-175), assim, tal como o mulo, animal resultante do cruzamento de jumento com égua ou de cavalo com jumenta, marcado pela infecundidade, seriam os mulatos igualmente estéreis.

Gostaríamos ainda de observar, na nota supracitada, a interlocução expressa pela exclamação lacunar "Ah! Afonso! Não te dizia...", a qual sugere ter esse tipo de reflexão ocupado anteriormente o raciocínio do autor que já desconfiara das reações suscitadas em razão da incompatibilidade entre sua

${ }^{79}$ Segundo Cunha (1982), o termo 'mulato' é de origem castelhana e data de 1524, inserido dentro do verbete 'mula'. Já Machado (1952-1959), aponta o registro de Gil Vicente (14651536 ?), trecho do escrito Clérigo da Beira, de 1526, como sendo a primeira ocorrência desse vocábulo. 
raça e ofício. Mais uma vez, a formulação de Silva (2005) expõe claramente essa ambiguidade decorrente dos quesitos cor e condição intelectual ao focalizar as trajetórias de Lima Barreto e Cruz e Souza:

Cruz e Lima não eram indivíduos aculturados, ou seja, não saíram de uma cultura, com padrões definidos, para outra que apresentasse diferentes concepções de vida. Como brasileiros letrados da época, desenvolveram-se dentro dos adaptados padrões culturais europeus. Contudo, a pobreza e a situação racial do período em que viveram, submetendo-os a inúmeros constrangimentos e restrições, indicam que, por aquelas circunstâncias, estariam vinculados à cultura popular, pelo menos nos primeiros anos de vida, além de tê-las como referência pelos vínculos familiares. Contudo, o vetor de suas pretensões, muito cedo, foi 0 da cultura letrada. $O$ desenvolvimento do exercício da escrita levou-os a dirigir suas atenções para as brechas da ideologia estética e seus pontos de desarticulação. Sabiam que as formas literárias tinham seus significados sociais, bem como que elas operavam no sentido de traduzir a conformação da hierarquia (lbid., p. 188).

Lima sabia muito bem das benesses que poderia gozar caso não estivesse condenado ao estigma racial de sua cor, ainda assim insistiu em mover-se num espaço ambivalente - o da cultura letrada, embora sua condição social o inscrevesse no subúrbio. A escrita, seja no diário ou na ficção, permitiuIhe ultrapassar as fronteiras desses espaços, desviar-se de padrões intelectuais, sociais, literários; possibilitando-o articular-se, expondo suas preocupações estéticas e pessoais em alguma medida livre de censura. Nesse sentido, concordamos com a consideração de Hidalgo (op. cit., p. 241), quando disse que "[s]em a escrita, restaria o isolamento, o abafamento da subjetividade".

O trafegar por e entre esses espaços causou-lhe muitos dissabores, conforme a repetição da palavra "desgosto", na passagem supracitada e em outros momentos das páginas íntimas, revela. Evocamos, sob esse prisma, o relato citado textualmente no primeiro capítulo dessa dissertação que diz 
respeito a Lima ter sido tomado sucessivas vezes como contínuo, enquanto na verdade era amanuense. Após declarar estar condenado a ser sempre rebaixado de função em virtude de ser mulato, objetou: "Entretanto, não me agasto, minha vida será sempre cheia desse desgosto e ele far-me-á grande. [...] Quando me julgo - nada valho; quando me comparo, sou grande. Enorme consolo" (DI, p. 52 - 26 de dezembro de 1904, grifos nossos). Destacamos a semelhança textual de ambas as frases sublinhadas: "cheia desse desgosto e ele far-me-á grande" e "Desgosto! Desgosto que me fará grande", a primeira de 1904 e a segunda do ano seguinte. Nesse ponto, notamos esse sentimento de aborrecimento figurar enquanto mola propulsora para a grandeza futura, dito de outro modo, movido por ele Lima avançaria em direção às glórias almejadas por meio do ofício de escritor. Parece que o mecanismo se processaria a partir dos constrangimentos por causa da condição racial que, por sua vez, gerariam aborrecimentos que o impulsionariam a prosseguir no intento traçado.

Faz-se oportuno pensarmos ainda com quem Lima se compara, talvez aos seus pares, logo ao comparar-se com outros tantos mulatos desprovidos de conhecimento letrado vê-se revestido de importância, ou seja, pensava gozar de privilégios pelo fato de ser um intelectual brasileiro. Essa parece ser a imagem que o eu confessional posto no diário fazia de si, via-se diferente em virtude da instrução formal recebida. Porém, a imagem social à vista na arena pública foi continuamente a de mulato. Com efeito, sua condição racial sempre fora colocada como fator mais significativo perante a sociedade, provavelmente razão pela qual o autor nunca foi vinculado à elite dos escritores brasileiros. E Lima tinha consciência das implicações intrínsecas à raça. 
Há dias, por motivos de minha profissão, fui obrigado a entrar na Secretaria de Estado das Relações Exteriores. Vestia-me mal, é fato; mas entrava certo de que era cidadão brasileiro, homem de algum cultivo, cumpridor dos meus deveres, e, sobretudo, protegido da crença que, tendo freqüentado uma dessas nossas escolas superiores, mereceria dos contínuos de lá o tratamento que se dá ao comum dos mortais. Enganei-me (DI, p. 109 - Sem data, 1905).

Podemos analisar esse excerto à luz da noção das prerrogativas, anteriormente considerada. Aqui Lima pensava lograr das seguintes: era cidadão brasileiro e letrado, logo merecia tratamento diverso do que the ofereceram. Ao que parece o desagrado foi grande, visto a sequência da nota: "[f]iquei atônito, nunca fora assim tratado em departamento da administração brasileira e demais naquele sotaque estrangeiro" (DI, p. 109 - Sem data, 1905). A consciência de Lima estendeu-se também aos constrangimentos sofridos por outros de seus pares, com os quais se solidarizou. São dignos de observação dois casos relatados.

Hoje, dia quente, cheguei um tanto mais tarde na secretaria. À minha banca, veio-me falar o Major Vital. Esse Major é um pretinho, fulá, magrinho, de crânio deprimido, olhos quase à superfície da fisionomia, pele de sapato velho que nunca foi engraxado. Esse pretinho usava farda de major honorário, e tendo estado no Paraguai, obtivera umas honras militares. Depois, com sucessivos acontecimentos, as honras foram aumentando e, um belo dia, surge um, em Pernambuco, de igual nome, branco, que também tinha estado na campanha. Papéis pra lá, papéis pra cá, o branco foi considerado como sendo o que de direito. O major foi despedido de servente do Arsenal de Guerra, excluído do asilo, ficou na miséria. Vou-lhe dar alguma roupa velha e uns cobres.

Não tenho absolutamente a convicção de que seja ele o verdadeiro major, nem tampouco que não é outro ou um terceiro; entretanto, julgo que a ele competiam as honras; pobre e obscuro, ele precisava qualquer coisa para disfarçar isso, e ainda mais negro ... ( $D I$, p. 81-82 - 10 de janeiro de $1905)^{80}$.

${ }^{80}$ Esse episódio rendeu matéria para Lima desenvolver o conto "A matemática não falha", publicado originalmente no volume Histórias e Sonhos, cuja primeira edição data de 1920. Esse foi o último livro publicado em vida por Lima Barreto. 
Dessa nota, torna-se saliente a caracterização do Major Vital, descrito pela ótica da raça - pretinho, fulá, de crânio deprimido -, demonstrando novamente que o olhar de Lima orientava-se por essa perspectiva, já que apresentou o adversário do provável major como branco, enfatizando, assim, o contraste. Do infortúnio daquele, pôs em relevo a necessidade de certo reconhecimento para sobrepujar os estigmas sociais e raciais. Sendo assim, somente as honras concedidas ao pobre pretinho poderiam dissimular sua condição fazendo-o parecer outro.

Nessa esteira, contou Lima:

Por falar nisso, o Belo, primeiro oficial, que foi do gabinete do Benjamin, contou-me que a nomeação do Hemetério (é um negro), para professor do Colégio Militar, foi sustada na gaveta por ordem do Lauro Sodré, que sempre lhe recomendava ao ele ir the pedir para expedir, que esperasse, que esperasse.

E singular que, fazendo eles a República, ela não a fosse de tal forma liberal, que pudesse dar um lugar de professor a um negro.

É singular essa República (DI, p. 82 - 10 de janeiro de 1905).

A percepção aguda de nossa conservadora organização republicana, proclamada pela elite, esclareceu as razões pelas quais um negro não poderia atuar como professor em um renomado estabelecimento de ensino. A respeito da relação de Lima com a singular República, vale conferir as palavras de Carvalho (1987, p. 30 ): "[a] simpatia dos negros pela Monarquia reflete-se na conhecida ojeriza que Lima Barreto, o mais popular romancista do Rio, alimentava pela República". Como é possível observar, em ambos os casos registrados por Lima, a possibilidade de ascensão do negro foi barrada pela burocracia do Estado, respaldado cientificamente pelos dogmas científicos vigentes. Nesse ponto, a consideração de Silva (2011), apontou esse 
mecanismo:

Com tais teorias - pretensamente científicas, pois a história demonstrou o contrário - adaptadas por brancos brasileiros para o cenário local, dá-se o início do grande arsenal de argumentos e falácias para justificar a exclusão dos negros e de seus descendentes da ascensão social, visando manter ou prolongar a ordem racial antiga (Ibid., p. 26).

Não causa espanto, pois, a aversão de Lima ao modo como a República fora aqui instituída, às bases teóricas que a fizeram menos res publica. Estava certo de que somente por meio de renome intelectual conseguiria burlar a lógica hostil republicana.

Mulato, desorganizado, incompreensível e incompreendido, era a única coisa que me encheria de satisfação, ser inteligente, muito e muito! A humanidade vive da inteligência, pela inteligência e para a inteligência, e eu, inteligente, entraria por força na humanidade, isto é, na grande Humanidade de que quero fazer parte (DI, p. 135 - 16 de julho de 1908).

O sentimento de indignação em virtude da aceitação passiva e incontestada dos modelos europeus demonstra o quanto lhe custou conviver com o peso das teorias raciais - "Desviei a corrente natural de minha vida, escondi-me em mim mesmo e fiquei a sofrer para sempre ..." (DI, p. 112 - Sem data, 1905). No tocante ao jugo perpetrado pela ciência, vale mencionar um conto inacabado de Lima cujo título "O peso da ciência"81 (BARRETO, 2010b, p. 566) põe a nu os percalços por ela infligidos. Breve, nesse conto composto de reminiscências dos tempos de escola, o narrador destaca a figura do professor de história universal - um preto, um negro que tinha o hábito de começar a aula

\footnotetext{
${ }^{81} \mathrm{O}$ primeiro contato com esse conto se deu por meio do manuscrito, quando de nossa visita à Biblioteca Nacional do Rio de Janeiro em julho de 2011. Foi escrito em folha do Ministério dos Negócios da Guerra, local onde Lima exercia a função de amanuense. Posteriormente, verificamos que esse conto consta na coletânea organizada por Lilia Moritz Schwarcz, fonte aqui indicada.
} 
citando um caso, "embrulhava com reminiscência sua, e acabava pessimisticamente como remarques à República, ao Brasil, às suas coisas e aos seus homens" (Ibid., p. 566). A simpatia do narrador para com o professor iniciou-se na lição que tratava "da divisão de raças" (Ibid., p. 566). Essa narrativa, ainda que incompleta, reitera essa temática presente nos escritos de Lima - a problemática da raça.

Ecoa das notas íntimas limabarretianas ora o azedume de quem destarte percebeu as contradições inerentes aos postulados raciais importados e pouco pôde fazer para combatê-los, ora somos surpreendidos pela auto-afirmação consciente de seus predicados intelectuais.

\begin{abstract}
Mas, hoje! Hoje! Já posso alguma coisa e amanhã poderei mais e mais. Não pararei nunca, não me deterei; nem a miséria, as perseguições, as descomposturas me deterão. Sacudi para longe o fantasma do medo; sou forte, penso, tenho coragem... Nada! Nada! Nada! É que senti que a ciência não é assim um cochicho de Deus aos homens da Europa sobre a misteriosa organização do mundo (DI, p. 112 - Sem data, 1905).
\end{abstract}

Afirma, nessa nota lapidar, seu ímpeto de prosseguir propagando sua voz trigueira, fincando-se, tal como Luiz Gama, como "negro-autor"; uma vez que, não obstante os desabafos em virtude das barreiras encontradas dada sua condição racial, Lima mostrou-se absolutamente consciente de sua cor, ou seja, ele afirmou a identidade negra. É fato, não deseja embranquecer para ser reconhecido. Nesse sentido, colocou-se na contramão do sistema, pois almejava a glória embora fosse mulato.

Ele, muito habilmente, compreendeu e sentiu o peso do passado de sua 
gente $^{82}$ e, por conseguinte, dos dogmas raciais que renegavam aos seus a condição de cidadão mesmo num país de regime republicano. Por esse viés, Lima elucidou "a covardia intelectual de que [nós brasileiros] estamos apossados em face dos grandes nomes da Europa" (DI p. 111 - Sem data, 1905). Consciente das incongruências inerentes às teorias raciais, prolongouse:

É satisfação para minh'alma poder oferecer contestação, atirar sarcasmos à soberania de tais sentenças, que me fazem sofrer desde os quatorze anos.

Oh! Ciência! Eu era menino, tinha aquela idade, andava ao meio dos preparatórios, quando li, na Revista Brasileira, os seus esconjuros, os seus anátemas... [...]

Eles me encheram de medo, de timidez, abateram-me; a minha jovialidade nativa, a satisfação de viver nesse fantástico meio tropical, com quem tenho tantas afinidades, ficou perturbada pelas mais degradantes sentenças (DI, p. 112 - Sem data, 1905).

Próximo aqui de um tom de desforra, compraz-se em atacar a legitimidade científica das sentenças raciais que tanto afetaram sua trajetória pessoal. Desse excerto, é possível acompanhar seu raciocínio na busca de encontrar o lugar daquilo que veio de fora no âmbito do contexto brasileiro. Nesse sentido, conforme se nota, condenou manifestadamente a adoção dessas teorias adotadas como meio de validar o tratamento dispensado aos negros e mestiços. Entendia que tais teorias não cabiam na realidade cultural de nosso país, pois "concebia a sociedade brasileira como o fruto da combinação de diferentes etnias e que, em virtude mesmo dessa mestiçagem, havia atingido um grau elevado de intimidade e adaptação à natureza tropical e vigente do país" (SEVCENKO, op. cit., p. 210).

\footnotetext{
${ }^{82}$ As avós de Lima, tanto materna (Geraldina Leocádia), quanto paterna (Carlota Maria dos Anjos) eram negras e ex-escravas.
} 


\subsection{Lima Barreto na Confluência das Teorias Raciais}

Nos espaços por onde se movimentou, Lima se apercebeu e foi percebido socialmente enquanto mulato. Surgiu, porém, do trânsito socialpessoal uma postura ambivalente em relação à descrença na ciência e ao modo como enxergou sua família. Ilustrativo desse dilema é a seguinte nota: "A Prisciliana e filhos, aquilo de sempre. Sem a distinção da cultura nossa, sem o refinamento que já conhecíamos, veio em parte talvez prender 0 desenvolvimento superior dos meus. Só eu escapo!" (DI, p. 41 - Janeiro de 1904). Prisciliana, é necessário esclarecer, foi uma negra ama-seca dos filhos de João Henriques de quem acabou tornando-se concubina. Essa malfadada relação, no entender de Lima, impediu a promoção de sua família. A respeito disso, desabafou: "a meu pai nunca perdoarei essa sua ligação com essa boa negra Prisciliana, que grandes transtornos trouxe a nossa vida" (DI, p. $76-03$ janeiro de 1905). Seu discurso não escapou das noções de superioridade e inferioridade largamente disseminadas nesse período. Interessante acompanhar o olhar de Lima que marcou a falta de distinção e de refinamento da cultura dessa negra em oposição à cultura nossa, ou seja, da que Lima filiava-se. Vinculava-se, portanto, a meio diverso, visto subtrair-se da natureza comum a tipos como Prisciliana. Percorrendo o Diário, no rastro dessas noções, encontramos semelhante observação:

A uma família que se junta uma outra, de educação, instrução, inteligência inferior, dá-se o que se dá com um corpo quente que se põe em contato com um meio mais frio; o corpo perde uma parte do seu calor em favor do ambiente frio, e o ambiente, ganhando calor, esfria o corpo.

Foi o que se deu conosco.

Eu, entretanto, penso me ter salvo ( $D I$, p. $76-03$ janeiro de 
1905, grifos nossos).

Lança mão de um conceito científico - o da calorimetria - para analisar a constituição familiar. O corpo quente seriam os seus em contraponto ao corpo frio representado pela gênese de Prisciliana. A diferença de nível destes quesitos - educação, instrução e inteligência -, quando do contato entre esses corpos determinou o resultado final de resfriamento daquele em detrimento desse, reduzindo a capacidade superior do mais quente. A distinção e o refinamento viriam por meio do alto grau de desenvolvimento dos três quesitos mencionados. Salientamos, uma vez mais, a ressalva posta no fim dessa nota, reveladora de certo desajuste do eu doméstico em relação aos seus, já que se via diferente, pensava escapar do entorpecimento causado pelo contato com o corpo frio. Instaura-se, assim, um conflito irresoluto decorrente da ambiguidade criada pelo seu status social enquanto mulato pobre e sua condição intelectual de homem de letras.

Eu tenho muita simpatia pela gente pobre do Brasil, especialmente pelos de cor, mas não me é possível transformar essa simpatia literária, artística, por assim dizer em vida comum com eles, pelo menos com os que vivo, que, sem reconhecerem a minha superioridade, absolutamente não tem por mim nenhum respeito e nenhum amor que lhes fizesse obedecer cegamente (DI, p. 76 - 03 de janeiro de 1905).

Lima, letrado consoante aos padrões culturais europeus, intelectualmente sentia-se superior, como é possível depreendermos do excerto supracitado. Reveladores de um sentimento exacerbado de superioridade, no plano da linguagem, são os advérbios absolutamente e cegamente, ambos expressam profundo desacordo entre o reconhecimento esperado por ele da parte da família e a submissão devido à sua preeminência. 
Sob esse prisma, detecta-se aí uma tensão mantida, pois ao mesmo tempo em que 0 escritor carioca assumia-se enquanto negro, distanciava-se intelectualmente das gentes de cor. Tal postura evidencia o deslocamento entre sua figura de intelectual e os membros de sua família. O problema que se coloca, nesse contexto, é o de que ao tentar salvar-se dos estigmas, não deixou de corroborar para a manutenção do abismo criado entre os brancos e "os de cor" por aqueles que manipulavam a ciência. Desse modo, embora contestasse as teorias raciais, não deixou de endossá-las em alguma medida, uma vez que se concebeu superior quando posto ao lado daqueles de igual condição social e racial. Não permaneceu, portanto, imune aos dogmas científicos.

Pautado no que classificaremos como decoro social por conta da $\operatorname{cor}^{83}$, Lima desvelava-se em cuidados com a irmã Evangelina. Tal posicionamento põe em relevo as diferenças entre moças brancas e negras, essas, a seu ver, deveriam resguardar-se mais das atenções dos rapazes. Buscando preservála, Lima assinalou, da maneira estabelecida pelos brancos, o lugar social do mulato ${ }^{84}$, pois recomendou o recato em virtude da condição racial da irmã, uma

\footnotetext{
${ }^{83}$ Ilustra esse decoro, no plano ficcional, a frase dita pela mãe do personagem Isaías Caminha (romance Recordações do Escrivão Isaías Caminha) quando este decide partir para a capital a fim de fazer-se doutor: "Vai, meu filho - disse-me ela afinal. - Adeus!... E não te mostres muito, porque nós..." (BARRETO, 2001, p. 128). O conselho ficou em suspenso, contudo, é possível deduzir a sequência. O filho deveria proteger-se dos percalços decorrentes da cor.

84 Exemplo significativo do lugar social do mulato, na ficção, é o momento em que a personagem Clara (romance Clara dos Anjos) se dá conta do engano em relação aos sentimentos de Cassi, a se ver grávida e abandonada: "Estava irremediavelmente perdida; ele a abandonava de vez. Como havia de ser? Como havia de esconder a gravidez, que se ia mostrando aos poucos? Que fariam dela os seus pais? Era atroz o seu destino! Todas essas perguntas, ela formulava e não lhes dava resposta. Cassi partira, fugira... Agora, é que percebia bem quem era o tal Cassi. O que os outros diziam dele era a pura verdade. A inocência dela, a sua simplicidade de vida, a sua boa fé, e o seu ardor juvenil tinham-na completamente cegado. Era mesmo o que diziam... Por que a escolhera? Porque era pobre e, além de pobre, mulata. Seu desgraçado padrinho tinha razão..." (BARRETO, 2001, p. 741). Em nota no Diário Íntimo (p. 113), Barbosa apontou as preocupações de Lima para com a irmã como a gênese de Clara dos Anjos.
} 
vez que conhecia os princípios morais reguladores das relações sociais entre brancos e negros. Tais precauções deviam-se, pois, à distinção observada no tratamento para com uns e outros, de acordo com a cor da pele, bem como à clareza dos argumentos agenciados pela elite para manter o negro ao longe da igualdade prometida após a abolição.

Ontem, eram onze horas, eu estava no meu quarto, escrevendo, passou um pequeno da vizinhança. Chegando em frente à nossa casa, deu boas-noites. Pelo jeito, pareceu-me que o dera para a minha irmã ou para a tal Paulina, que é uma vulgar mulatinha, muito estúpida, cheia de farofas de beleza e de presunção, que é ou pode ser namorada. Achei aquilo inconveniente. Que um sujeito, passando por uma casa fechada, desse boas-noites a moças recolhidas num quarto de dormir. Nesse sentido, inquiri minha irmã, que desmentiu. Há em minha gente toda uma tendência baixa, vulgar, sórdida. Minha irmã, esquecida que, como mulata que se quer salvar, deve ter um certo recato, uma certa timidez, se atira ou se quer atirar a toda a espécie de namoros, mais ou menos mal intencionados, que lhe aparecem. [...]

Se a minha irmã não fosse de cor, eu não me importaria, mas o sendo dá-me cuidados, pois que, de mim para mim, que conheço essa nossa sociedade, foge-me o pensamento ao atinar porque eles as requestam ( $D I$, p. 75-76 - 03 de janeiro de 1905, grifos nossos).

À vista dessa violenta impressão de sua gente, não podemos ignorar a atribuição de valores negativos no tocante à direção para onde os seus inclinavam-se a mover-se, expressa pela sentença: "Há em minha gente toda uma tendência baixa, vulgar, sórdida". Os adjetivos selecionados - baixa, vulgar e sórdida - caracterizadores dessa tendência, encerram a ideia de decadência, declínio, rebaixamento. Visão essa própria dos postulados raciais aqui disseminados como verdades absolutas. Com efeito, esse juízo negativo que fez dos seus era o juízo coletivo naquele momento. Uma vez mais, a consideração de Lima não se encontrou isenta da ideologia aportada pelas 
teorias hegemônicas. Nesse bojo, o lamento ao descrever o comportamento do pai e do irmão, estende-se de algum modo pela esteira dos estigmas raciais: "Meu pai, ambulante, leva a vida imerso na sua insânia. Meu irmão, C ..., furta livros e pequenos objetos para vender. Oh! Meu Deus! Que fatal inclinação a desse menino" (DI, p. 41 - Janeiro de 1904). Do pai, destacou a loucura que Ihe acometia desde 1902, do irmão a propensão para o roubo, traços ignóbeis, ou seja, confirmando a tendência baixa, vulgar, sórdida de sua gente.

Convém, todavia, observar que ele não se eximiu do caráter mestiço, antes afirmou pertencimento à raça negra ao servi-se do pronome possessivo minha de par com o vocábulo gente. Sublinhamos ainda o pragmatismo de Lima que compreendeu bem qual era o único meio de ascensão para negros e mestiços - a educação formal. Instaura-se por esse viés uma tensão à medida que Lima experimenta o drama daquele que vivencia a urgência de transcender as marcas impressas pela esfera científica bem como pela realidade concreta de sua gente. Ei-lo emparedado. No espaço do diário delineia-se, por essa perspectiva, a fresta por onde ele se movimenta na busca de tentar equalizar o protesto público contra as teorias raciais, posto afirmar-se enquanto escritor negro e a fragilidade íntima, dado a suposta vulnerabilidade de sua família. Para Lima, ladeado no espaço familiar pela insânia do pai, a inclinação do irmão para o roubo e da irmã para os namoros, além da própria sina do alcoolismo e, no espaço social, pelas teorias que o rebaixavam, negando-lhe usufruir das prerrogativas de escritor, vê-se paulatinamente encerrado no vão do Diário.

A posição do emparedado é também, de certa forma, a condição do mulato, uma vez que nem é negro, nem é branco, permanecendo assim em um 
entre-lugar racial. Esse espaço entre abre-lhe a brecha de optar pela identidade branca ou negra, visto constituir-se no plano biológico por caracteres de uma e outra raça.

O mestiço brasileiro simboliza plenamente essa ambiguidade, cuja consequência na sua própria definição é fatal, num país onde ele é de início indefinido. Ele é "um e outro", "o mesmo e o diferente, "nem um nem outro, "ser e não ser", "pertencer e não pertencer (MUNANGA, 2008, p. 119).

Essa ambivalência, contudo, não consegue ser mantida no plano político, pois do mulato sobressaí-se os traços negros de modo a reduzi-lo socialmente, impedindo-o de ascender ao lugar social de branco. No que tange Lima Barreto, vale reafirmar sua identificação à identidade negra, carregando consigo todas as ambiguidades decorrentes de sua condição racial e social mulato letrado com pretensões a escritor. Semelhante posição ocupou o já referido poeta Cruz e Sousa, igualmente neto de escravos, cujo emparedamento traduziu-se com todo vigor no texto de título indicativo dessa condição - "Emparedado". Movido pela consciência dos discursos legitimadores das diferenças insolúveis entre negros e brancos que cerceou o espaço de atuação do escritor negro, ele descreveu:

Se caminhares para a direita baterás e esbarrarás (...) numa parede horrendamente incomensurável de Egoísmos e Preconceitos! Se caminhares para a Esquerda, outra parede, de Ciências e Críticas, mais alta do que a primeira (...) Se caminhares para a frente, ainda nova parede, feita de Despeitos e Impotências (...) Se caminhares, enfim, para trás, ah! Ainda uma derradeira parede, fechando tudo, fechando tudo - horrível! - parede de Imbecilidade e Ignorância, te deixará num frio espasmo de terror absoluto... (CRUZ E SOUSA, op. cit., p. 631).

Revelador de reflexão parecida é o trecho abaixo extraído do conto 
"Dentes negros, cabelos azuis" de Lima Barreto:

[...] tenho que ir na vida pela senda estreita da prudência e da humildade, não me afastarei dela uma linha, porque à direita há os espeques dos imbecis, e à esquerda, a mó da sabedoria mandarinata ameaça triturar-me. Inclino-me daqui; inclino-me dali; e em torno recebo a carícia do ilimitado, do vago, do imenso. Se a corda estremece acovardo-me logo, o ponto de mira me surge recordado pelo berreiro que vem de baixo, em redor aos gritos: homem de cabelos azuis, monstro, neurastênico. E entre todos os gritos soa mais alto o de um senhor de cartola, parece oco, assemelhando-se a um grande corvo, não voa, anda chumbado à terra, segue um trilho certo cravado ao solo com firmeza - esse berra alto, muito alto: "Posso the afirmar que é um degenerado, um inferior, as modificações que ele apresenta correspondem a diferenças bastardas, desprezíveis de estrutura física; vinte mil sábios alemães, ingleses, belgas, afirmar e sustentam"... Assim vivo (BARRETO, 2010b, p. 327-328).

Gama, Cruz e Lima demonstraram igual consciência das muralhas erigidas em nome da ciência. Notaram claramente a propriedade concedida a qualquer teoria, desde que calcada em princípios ditos científicos. Dessa clareza decorrem seus comentários acerca do quesito cor, elemento fundamental usado para infamá-los.

Bode, negro, Mongibelo;

Porém eu que não me abalo,

Vou tangendo o meu badalo

Com repique impertinente,

Pondo a trote muita gente.

Se negro sou, ou sou bode,

Pouco importa. O que isto pode? (GAMA, op. cit., p. 116) ${ }^{85}$.

Deus meu! por uma questão banal da química biológica do pigmento ficam alguns mais rebeldes e curiosos fósseis preocupados, a ruminar primitivas erudições, perdidos e atropelados pelas longas galerias submarinas de uma sabedoria infinita, esmagadora, irrevogável (CRUZ E SOUSA, op. cit., p. 625$)^{86}$.

Seria ocioso mostrar o fato da cor ter significações diversas

\footnotetext{
${ }^{85}$ Trecho extraído do poema "Quem sou eu?".

${ }^{86}$ Trecho extraído do texto "Emparedado".
} 
para o físico, para o químico e para o biólogo, e exemplos seriam não fáceis de encontrar, mas inúteis para a certeza. $\mathrm{O}$ que define uma ciência não é o objeto que ela considera, é o ponto de vista em que ela o considera (DI, p. 37 - Sem data, 1903).

Retornando nossa lente para Lima Barreto, observamos que esse eu enredado pela contradição de se ver como um negro superior não pôde prescindir das páginas íntimas a fim de avaliar, a partir de seu olhar particular, os meandros do trânsito social-pessoal percorrido nos espaços familiar e público e destes para o espaço confessional do Diário, transferindo o peso das emoções e dos pensamentos para o papel. Dessa contradição irresoluta nasceu a potência da crítica social e política germinada no espaço subjetivo diarístico, configurando uma marca opaca de resistência contornada pelo drama íntimo e ao mesmo tempo público da consciência desse "negro-autor". 


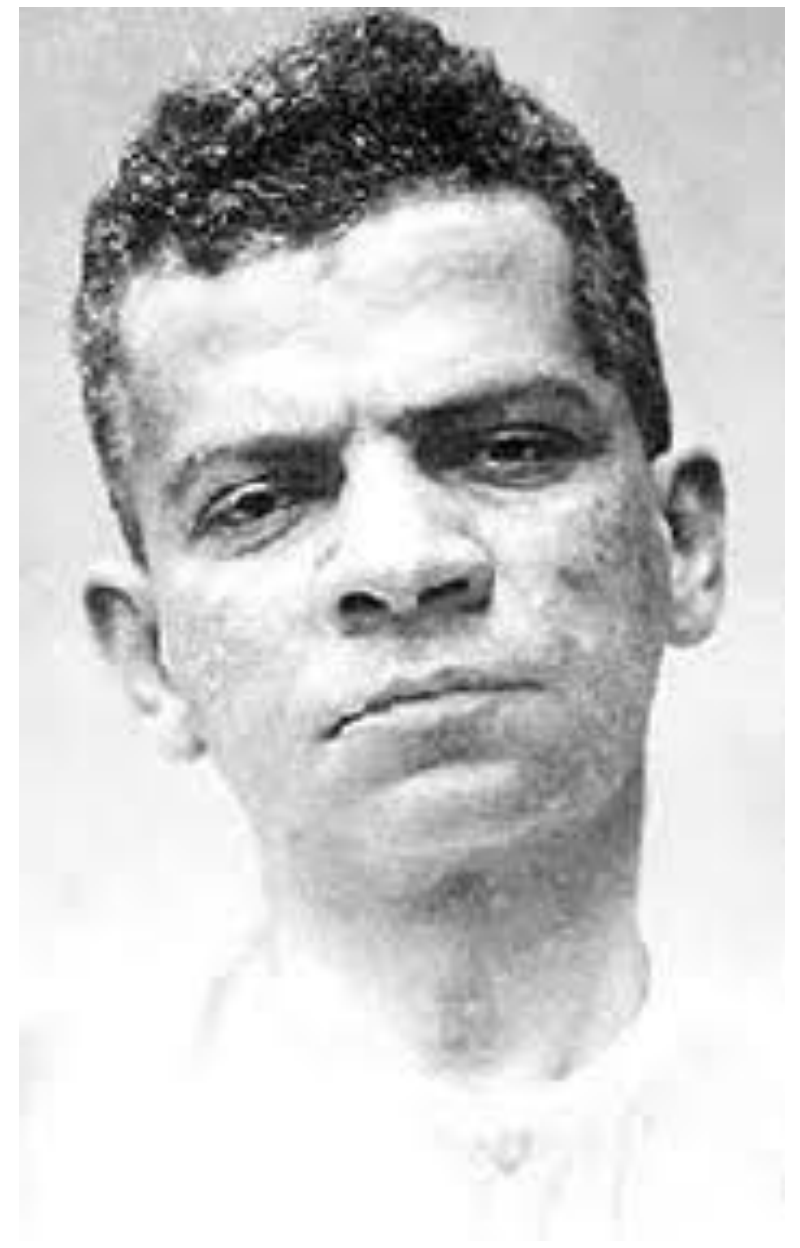

"O maior desalento me invade. Tenho sinistros pensamentos. Ponho-me a beber; paro. Voltam eles e também um tédio da minha vida doméstica, do meu viver quotidiano, e bebo. Uma bebedeira puxa outra e lá vem a melancolia. Que círculo vicioso! Despeço-me de um por um dos meus sonhos."

(Diário Íntimo) 


\section{Conclusão}

Reatar os fios do percurso-discurso de Lima Barreto traçado nas páginas íntimas, marcado por constante deslocamento do autor, implica focalizarmos um pouco mais o eu limabarretiano posto nesse espaço. Com efeito, segundo assinalou Prado (1976), grande parte das notas do Diário Íntimo relacionaram-se com a circulação do autor pela cidade do Rio de Janeiro.

Tal é a tônica do DIÁRIO: constantemente chegando, ou sempre saindo, as notas refazem um cotidiano irregular $\mathrm{e}$ instável; quase sempre os registros fixam o movimento: no trem, onde ora está com amigos, ora sozinho presenciando acidentes ou olhando absorto a beleza indiferente das jovens dos subúrbios; nas caminhadas ao Leme, ou no alvoroço da Rua do Ouvidor; nas visitas desencontradas e amigos obscuros dos bairros afastados. Sempre, diante do desencontro, a imagem instantânea de impressões que ficam, como sobras, recompostas à distância, parcializando as coisas captadas ao acaso e devolvidas imprecisamente ao leitor (lbid., p. 57).

Se à primeira vista essa circulação pelo espaço físico carioca pode confirmar o caráter boêmio atribuído ao autor, tomada por sentido mais agudo, levou-nos a entrever as impressões de Lima acerca dos lugares por onde se movimentou e de que modo sua persona fora notada. Pontuado pelo viés da intimidade, os caminhos por ele trilhados possibilitaram-nos enxergar os desdobramentos do eu no âmbito privado do Diário.

No espaço diarístico, o eu confessional mostrou-se arrefecido, frágil diante da hostil realidade de uma vida assinalada pelo aperto no orçamento doméstico, abandono dos sonhos, desajuste em relação à família e à sociedade, dado a discordância entre a condição intelectual e racial do autor, tal como a sociedade encarava os mestiços. Em suma, "sem dinheiro, sem 
família, carregado de dificuldades e responsabilidades" (DI, p. 135 - 16 de julho de 1908), esse eu encontrou na forma do diário íntimo expressão justa para as experiências de sofrimento, do declínio de si, consequência do vício do álcool; para exteriorizar o mal-estar decorrente do desacordo do eu doméstico e social. Se por um lado, as notas do Diário relativas ao ambiente familiar permitem-nos apontar um eu doméstico tomado por profundo desgosto em virtude da opinião que tinha da inclinação baixa, vulgar e sórdida de sua gente, por outro, revela um orgulho exacerbado da condição de intelectual, fator que, a seu ver, o diferenciava dos familiares e, por conseguinte, dos demais negros e mulatos desprovidos de instrução formal. Foi essa a força motriz que impulsionou o eu social a não arrefecer diante das teorias raciais, que o levou a afirmar-se enquanto mulato consciente das manobras diligenciadas pela elite a fim de escamotear as diferenças entre brancos e negros, evidentemente presentes no trato do dia-a-dia para com uns e outros, conforme pudemos acompanhar o relato das situações adversas passadas por Lima e outros de igual condição social e racial.

Nesse ponto, lembremos que, passado apenas um ano da abolição da escravatura, o hino à Proclamação da República, cuja letra fora publicada no Diário Oficial em 21 de janeiro de 1890, entoava a "esperança de um novo porvir" de uma elite que dizia:

Nós nem cremos que escravos outrora, Tenha havido em tão nobre país Hoje o rubro lampejo da aurora, Acha irmãos, não tiranos hostis. Somos todos iguais, ao futuro Saberemos unidos levar, Nosso augusto estandarte, que puro, 
Brilha ovante, da Pátria no altar $^{87}$.

Refletir sobre as facetas do eu limabarreteano, indispensavelmente arrasta-nos aos desajustes bováricos apreendidos do divã da página branca. Retomando as duas vertentes do esquema elaborado por Lima quando da leitura da obra $O$ Bovarismo de Jules Gaultier, citado no segundo capítulo, observamos que a "pessoa humana" resultava da "imagem que sob o império do meio, circunstâncias exteriores, educação, sujeição, a pessoa forma de si mesmo" (DI, p. 94 - 28 de janeiro de 1905); ora, essa definição, provavelmente, corroborou para Lima conceber-se superior à medida que se pautou no conhecimento letrado adquirido para formar um eu social pretensamente eximido das noções de inferioridade atribuída aos mestiços; diz respeito, portanto, ao entendimento do valor social da educação formal na República, meio para a ascensão de negros e mestiços. A outra vertente definiu a "pessoa humana" como o "ser real, ideal, tendências hereditárias" (Ibid., p. 94); esse aspecto parece apontar para a fragilidade do eu doméstico, que embora não deixasse de ver-se como superior, enxergou, à luz das teorias raciais, a vulnerabilidade decorrente da herança familiar. Na sequência dessas definições, anotou Lima: "[a]s linhas se coincidem quando a impulsão, vinda do meio circunstancial, age no mesmo sentido que a impulsão hereditária" (Ibid., p. 94). Dito de outro modo, a convergência dessas duas definições da imagem de si eliminaria o caráter bovárico, ou seja, a diferença entre aquilo que se é e se acredita ser, pois "[a] vítima do bovarismo está consciente de uma distância, um hiato, entre suas aspirações e sua capacidade em realizá-las" (OAKLEY,

\footnotetext{
${ }^{87}$ Trecho do Hino à Proclamação da República, letra de Medeiros e Albuquerque (1867-1934) e música de Leopoldo Miguez (1850-1902).
} 
2011, p. 19). No caso de Lima Barreto, essas definições absolutamente não se fundiram, visto que a sociedade (meio circunstancial) o movia para longe do ofício de escritor, impelida pela crença na inferioridade racial. Agiu no mesmo sentido contrário a "impulsão hereditária", já que descendia da infamada raça negra. Desse modo, o afastamento entre o eu social (combativo, à mostra na sociedade) e o doméstico (vulnerável pela herança hereditária), revelou o drama íntimo do eu confessional (fragilizado) que, consciente do seu bovarismo, desejou uma "vida grande, nobre, plena de força e elevação" ( $D I$, p. 96 - 31 de janeiro de 1905). Todavia, as circunstâncias exteriores Ihe foram adversas para a realização do seu ideal, conforme verificamos a repulsão no espaço público aos escritores marcados pelos estigmas raciais, tais como Lima Barreto, Cruz e Souza e Luiz Gama.

Nos espaços por onde Lima circulou - as letras, o jornalismo, as ruas do Rio, a casa, o Diário - as impressões fixadas relacionaram-se em alguma medida com a perspectiva racial, aspecto entranhado nas mentalidades de brancos e negros intelectualizados. Persuadido de que apenas 0 reconhecimento de sua inteligência poderia levá-lo a ser agraciado enquanto escritor, mudando a imagem à mostra na arena pública, Lima, dotado de substancial base teórica, desvelou-se à literatura, com quem afirmou ter se casado (BARRETO, 1956b, p. 66). Selado o compromisso com o ofício de literato, debruçou-se sobre os modelos estrangeiros, estabelecendo diálogo crítico com os autores mais representativos ao longo do périodo em que viveu - até a década de 1920.

Dos modelos, destacou-se o referencial francês, conforme nossos levantamentos evidenciaram. Contato que o manteve ligado ao círculo 
canônico literário, uma vez que, a literatura francesa àquela época gozava de enorme prestígio. Entretanto, é fundamental analisarmos a postura de Lima Barreto face aos modelos estrangeiros, pois, embora sua formação tenha se dado visivelmente por meio das leituras de obras francesas ou em francês, ele não aderiu irrefletidamente às ideias estrangeiras, antes ponderou, discutiu, avaliou para então legitimar ou não o pensamento europeu. É possível percebermos que ele refletiu tentando encontrar o lugar daquilo que veio de fora no âmbito do contexto brasileiro. Assim procedeu com o projeto de escrever seu Germinal negro cujo modelo seria a obra francesa de Zola, contudo, a matéria constitutiva seria brasileira - "a vida e o trabalho dos negros numa fazenda". Rechaçou temas literários alheios à nossa realidade, bem como a forma de "realização puramente literária" (SILVA, 2006, p. 103), atenta apenas à fruição estética.

Eu tenho notado nas rodas que hei frequentado, exceto a do Alcides, uma nefasta influência dos portugueses. Não é o Eça, que inegavelmente quem fala português não o pode ignorar, são figuras subalternas: Fialho e menores.

Ajeita-se o modo de escrever deles, copiam-se-lhes os cacoetes, a estrutura da frase, não há dentre eles um que conscienciosamente procure escrever como o seu meio o pede e o requer, pressentindo isso na tradição dos escritores passados, embora inferiores. É uma literatura de concetti, uma literatura de clube, imbecil, de palavrinhas, de coisinhas, não há neles um grande sopro humano, uma grandeza de análise, um vendaval de epopéia, o cicio lírico que há neles é mal encaminhado para a literatura estreitamente pessoal, no que de pessoal há de inferior e banal: amores ricos, mortes de parentes e coisas assim. A pouco e pouco, vou deixando de os frequentar, abomino-lhes a ignorância deles, a maldade intencional, a lassidão, a covardia dos seus ataques ( $D I, p$. 100, Sem data - 1905).

Movido pelo ideal da literatura enquanto "realização substancialmente social' (SILVA, 2006, p. 103), voltou-se para os aspectos sociais à vista por 
onde circulou, conteúdo tratado de modo a sensibilizar politicamente o leitor (Ibid., p. 103). Sob esse prisma é que se pode compreender o olhar de Lima volvido, sobretudo para os pobres, negros e mestiços. Focalização nítida dessa maneira de ver encontra-se no conto "O domingo", no qual observou as pessoas no bonde.

Eram meninas do povo envolvidas nos seus vestidos empoados com suas fitinhas cor-de-rosa ao cabelo e o leque indispensável; eram as baratas casemiras claras dos ternos; eram as velhas mães, prematuramente envelhecidas com a maternidade frequente, a acompanhar a escadinha dos filhos, ao lado dos maiores, ainda moços, que fumavam os mais compactos charutos do mercado - era dessa gente que se enchia o bonde e se via pelas calçadas em direção aos jardins, aos teatros em matiné, aos arrabaldes e às praias. Era enfim o povo, o povo variegado da minha terra. As napolitanas baixas com seus vestidos de roda e suas africanas, as portuguesas coradas e fortes, caboclas, mulatas e pretas - era tudo sim preto, às vezes todos exemplares em bando, às vezes separados, que a viagem de bonde me deu a ver (BARRETO, 2010b, p. 589).

A clareza que tinha do penoso cotidiano dessa gente, da qual fazia parte, aliada à consciência das noções científicas de superioridades e inferioridades levou-o a refletir acerca dos rumos políticos dados à nação.

E muito me fez meditar o seu semblante alegre, a sua força prolífica, atestada pela cauda de filhos que arrastavam, a sua preocupação nas anemias que havia, em nada significando a preocupação de seu verdadeiro estado - e tudo isso muito me obrigou a pensar sobre o destino daquela gente (lbid., p. 589).

Era essa faculdade de compreender as bases teóricas que respaldava o Estado a não cumprir concretamente com os ideais de igualdade, liberdade e fraternidade republicanos que o fazia sentir-se superior e o impulsionava a buscar, por meio de sua pena, inflamar a discussão sobre o lugar social relegado a negros e mestiços. Em relato no Diário, em ocasião de viagem a 
São Gonçalo, lembrou-se das origens de sua avó materna que viveu por aquelas paragens, passou então a conjecturar:

Quem sabe se eu não tinha parentes, quem sabe se não havia gente do meu sangue naqueles párias que passavam cheios de melancolia, passivos e indiferentes, como fragmentos de uma poderosa nau que as grandes forças da natureza desfizeram e cujos pedaços vão pelo oceano afora, sem consciência do seu destino e de sua força interior. (...)

Eu me lembrei que a grande família de cuja escravatura saíra minha avó, tinha se extinguido, e que deles, diretamente, pelos laços de sangue e de adoção, só restavam um punhado de mulatos, muitos, trinta ou mais, de várias condições, e eu era 0 que mais prometia e o que mais ambições tinha (DI, p. 131 10 de fevereiro de 1908).

Essa postura sensível ao destino de sua gente tornou-o ativo escritor social, destoando da conduta de muitos dos literatos seus contemporâneos. A respeito do posicionamento distinto de Lima Barreto, Carvalho (1987) chamou atenção para suas preocupações estéticas, visto sua produção textual e a de Euclides da Cunha, despontarem como exceções em meio aos olhares voltados irrestritamente para o cenário europeu.

O brilho republicano expressou-se em fórmulas europeias, especialmente parisienses. Mais que nunca, o mundo literário voltou-se para Paris, os poetas sonhavam viver em Paris e, sobretudo, morrer em Paris. Com poucas exceções, como o mulato Lima Barreto e o caboclo Euclides da Cunha, os literatos se dedicaram a produzir para o sorriso da elite carioca, com as antenas estéticas voltadas para a Europa (CARVALHO, 1987, p. 39).

Foram as escolhas estéticas de Lima - recusa do "artificialismo estilístico" (PRADO, op. cit., p. 20) de uma linguagem rebuscada ${ }^{88}$, opção por

\footnotetext{
${ }^{88}$ Não iremos aqui desenvolver reflexão sobre as concepções de Lima sobre linguagem, vale citar, no entanto, um trecho do Diário que revela o que pensava da retórica: "Rui [Barbosa], o letrado beneditino das coisas de gramática, artificiosamente artista e estilista, aconselha pelos jornais condutas ao governo. Há dias, ele, no auge da retórica, perpetrou uma extraordinária mentira. Referindo-se ao dia 14, que fora cheio de apreensões, de revoltas e levantes, e à nota
} 
temas de caráter ideológico, percepção da literatura como meio de exprimir a realidade - que o fizeram uma personalidade excêntrica, pois escapava da norma vigente, à medida que sua postura e opções literárias o mantiveram fora do centro canônico. Decorreu daí sua opção por escrever um "diário extravagante". Nesse sentido, à medida que se esquivou do modelo da literatura oficial, propondo outra forma literária, erigiu postura contrahegemônica, processada de modo a combater o fazer literário que excluía personagens e temáticas da realidade local. Entrevemos nesse ponto certo vanguardismo de sua parte ao posicionar-se desse modo, bem como ao pensar em criar o "negrismo". Lido pela distinção proposta por Lefebvre (1969) no tocante aos conceitos de modernismo e modernidade, parece-nos que Lima aproxima-se mais do segundo termo, entendido como "uma reflexão principiante, um esboço mais ou menos adiantado de crítica e de autocrítica, numa tentativa de conhecimento" (Ibid., p. 4) em oposição a modernismo concebido como "a consciência que tomaram de si mesmas as épocas, os períodos, as gerações sucessivas; o Modernismo consiste, pois, em fenômenos de consciência, em imagens e projeções de si, em exaltações feitas de muitas ilusões e de um pouco de perspicácia" (Ibid., p. 4). Por essa perspectiva, cabe-Ihe caracterizá-lo enquanto escritor moderno à medida que contribuiu para abalar o modelo tradicional de uma literatura em transição para o Modernismo.

Com efeito, em um momento em que se buscava branquear o Brasil, Lima tingiu suas páginas de negros e mestiços, atentando para o drama íntimo

trazida a 15, da vitória da 'legalidade', disse assim, da manhã de 15: 'fresca, azulada e radiante', quando toda a gente sabe que essa manhã foi chuvosa, ventosa e hedionda. Eis até onde leva a retórica; e depois..." (DI, p. $51-22$ de novembro de 1904). 
desses tipos rebaixados pela ciência. Faz-se necessário, porém, notar que ele não permaneceu imune às vicissitudes e postulados de seu tempo, pois se analisou pessoal e familiarmente a partir das noções raciais científicas. As reflexões no Diário mostraram estarmos diante de uma personalidade cindida, já que ora duvidou, combateu as teorias raciais, ora apoiou-se na fatalidade hereditária do processo de miscigenação para observar a constituição de sua família e o comportamento de sua gente. Clivada foi também a forma como encarou a hegemonia da Europa. Se ao afirmar "[e]u veria a Vitória de Samotrácia com o mesmo olhar e a mesma emoção com que vejo um manipanso africano. São documentos sociais ambos" (DI, p. 206 - Março de 1919), colocou-se antagonicamente à frente de seu tempo afastando-se do deslumbramento de tudo que provinha da cultura europeia; ao expressar "não quer[er] morrer sem uma viagem à Europa, bem sentimental e intelectual, bem vagabunda e saborosa, como a última refeição de um condenado à morte" ( $D I$, p. 171 - 20 de abril de 1914), deixou-se fascinar pelos encantos do Velho Mundo.

Para esse sujeito enredado nas tramas de seu tempo, as páginas íntimas configuraram-se o espaço encontrado para mover-se, imprescindível, portanto, ao protagonismo do eu social, às incertezas do eu doméstico, à fragilidade do eu confessional, facetas que conjugadas traduziram os embates da consciência íntima de Lima Barreto, que em todo tempo buscou exprimir-se de modo a afirmar a legitimidade de seu lugar intelectual pelos seus escritos.

Se não disponho do Correio da Manhã ou do O Jornal, para me estamparem o nome e o retrato, sou alguma coisa nas letras brasileiras e ocultarem o meu nome ou o desmerecerem, é uma injustiça contra a qual eu me levanto com todas as armas 
ao meu alcance (BARRETO, 1961b, p. 44).

Certo da autenticidade de seu ofício, pretendia como escritor

[...] esclarecer fatos e opiniões, sob a luz de uma livre crítica, de forma que aqueles leitores, pouco enfronhados nos bastidores de certos aspectos da nossa vida e deles só tendo diante de si o fato bruto, possam melhor julgar o desenrolar dos acontecimentos políticos, literários e outros, assim também as individualidades envolvidas nesses acontecimentos (DI, p. 194 - Outubro de 1917).

Das páginas íntimas, vê-se que por trás do escritor (mestiço, pobre, culto, inteligente) havia um cidadão da República, um ser humano igual a outros - livre e fraterno. Decorre do teor de suas notas a necessidade de o focalizarmos do ponto de vista biográfico, da produção literária, atentando à tensão entre a educação formal recebida e o sujeito social que buscou construir, apoiado numa perspectiva utópica de uma literatura de solidariedade delineada em um terreno de confronto entre ideologia dominante versus perspectivas não hegemônicas, espaço onde Lima tenta equilibra-se e se inscreve enquanto "negro-autor". 


\section{Bibliografia}

\section{Obras de Lima Barreto}

BARRETO, Lima. Diário Íntimo. São Paulo: Editora Mérito, 1953.

. Diário Íntimo. São Paulo: Brasiliense, 1956a.

. Impressões de leitura. São Paulo: Brasiliense, 1956b.

. O Cemitérios dos vivos. São Paulo: Brasiliense, 1956c.

. Bagatelas. São Paulo: Brasiliense, 1961a.

. Marginália. São Paulo: Brasiliense, 1961b.

. Diário Íntimo. São Paulo: Brasiliense, 1961c.

- Lima Barreto: Prosa seleta. Organização Eliane

Vasconcellos. Rio de Janeiro: Nova Aguilar, 2001.

- Diário do Hospício; Cemitério dos vivos. Organização

Augusto Massi e Murilo Marcondes de Moura. São Paulo: Cosac Naify, 2010a.

. Contos completos. Organização e introdução Lilia Moritz

Schwarcz. São Paulo: Companhia das Letras, 2010b.

Manuscritos consultados de Lima Barreto ("Coleção Lima Barreto", Seção de Manuscritos da Biblioteca Nacional)

Notas e Escritos [19_]. I - 6, 35, 943.

Notas sobre o 13 de Maio de 1888. I - 06, 36, 1022.

Notas, Cartões, Recortes de jornais e outros [19_]. I- 02, 04, 045.

O peso da Ciência [19_]. I - 06, 35, 0957.

Notas de um Diário 1904 - 1914 [19__. I - 06. 29; I -06. 033 (microfilme). 
O Escravo [19_]. I - 6, 35, 949.

Os Negros - cena imitada de Maurice Matterlinck 21/09/1915. 34A, 1, 972.

Jornais e Revistas. I -6, 35, 0930.

Carta a Celestin Bouglé. I -6, 28, 0023.

Carta a Dioclésio Duarte, Rio, 16 de junho de 1919. I -6, 28, 0036.

Carta-Bilhete a Rui Barbosa. I -6, 28, 0010.

\section{Fortuna crítica de Lima Barreto}

ALMEIDA, Milene Suzano de. Lima Barreto lê Anatole France. In: XII Congresso Internacional da ABRALIC Centro, Centros - Ética, Estética, 2011, UFRP, Curitiba. Anais. Disponível em: http://www.abralic.org.br/anais/cong2011/AnaisOnline/resumos/TC0554-1.pdf. Acesso em: 10 de novembro de 2011.

BARBOSA, Francisco de Assis. A vida de Lima Barreto. Rio de Janeiro: José Olympio, 2003.

BEIGUELMAN, Paula. Por que Lima Barreto. São Paulo, Brasil : Brasiliense, 1981.

BOTELHO, Denílson. A pátria que quisera ter era um mito: o Rio de Janeiro e a militância literária de Lima Barreto. Rio de Janeiro: Secretaria Municipal de Cultura, Departamento Geral de Documentação e Informação Cultural, Divisão de Editoração, 2002. (Coleção Biblioteca Carioca, v. 44. Série Literatura).

CAMPOS, Maria Tereza Arruda. Lima Barreto. São Paulo: Ática, 1988.

COELHO, Haydée Ribeiro. "Lima Barreto". In: DUARTE, Eduardo de Assis (org.). Literatura e Afrodescendência no Brasil: antologia crítica. Belo Horizonte: Editora da UFMG, 2011. v. 1. 
FANTINATI, Carlos E. O profeta e o escrivão: estudo sobe Lima Barreto. São Paulo: Hucitec, 1978.

FERREIRA, Luciana da Costa. Um personagem chamado Lima Barreto. Rio de Janeiro, 2007. 147 f. Dissertação (Mestrado) - Faculdade de Letras, Universidade do Rio de Janeiro.

FIGUEIREDO, Carmem Lúcia Negreiros de. Lima Barreto e o fim do sonho republicano. Rio de Janeiro: Tempo Brasileiro, 1995. - Trincheiras de sonho: ficção

e cultura em Lima Barreto. Rio de Janeiro: Tempo Brasileiro, 1998.

FREIRE, Zelia Nolasco. Lima Barreto, imagem e linguagem. São Paulo: Annablume, 2005.

GILENO, Carlos Henrique. Lima Barreto e a condição do negro e do mulato na Primeira República (1889-1930). São Paulo: Annablume, 2010.

HIDALGO, Luciana. Literatura da urgência: Lima Barreto no domínio da loucura. São Paulo: Annablume, 2008.

HOSSNE, Andrea Saad. A angústia da forma e o bovarismo: Lima Barreto, romancista. São Paulo, 1999. 229 f. Tese (Doutorado) - Faculdade de Filosofia, Letras e Ciências Humanas, Universidade de São Paulo.

KNABBEN, Maria Terezinha. O diário de Lima Barreto - da intimidade à historicidade e à literariedade. Eletras, São Paulo, v. 20, n. 20, p. 118-135, jul. 2010.

LINS, Osman. Lima Barreto e o espaço romanesco. São Paulo: Ática, 1976. MACHADO, Maria Cristina Teixeira. Lima Barreto, um pensador social na Primeira República. Goiânia: Editora da UFG; São Paulo: Edusp, 2002.

MARTINS, Eliete Marin. Diário Íntimo - documento da memória, criação 
estética - uma dupla leitura. Brasília, 2008. 155 f. Dissertação (Mestrado) Instituto de Letras, Universidade de Brasília.

OAKLEY, Robert John. Lima Barreto e o destino da literatura. São Paulo: Editora da Unesp, 2011.

ORNELLAS, Clara Ávila. João Antônio, Leitor de Lima Barreto. São Paulo: Edusp, 2011.

PRADO, Antonio Arnoni. Lima Barreto: o crítico e a crise. Rio de Janeiro: Cátedra; Brasília: INL, 1976.

RESENDE, Beatriz. Lima Barreto e o Rio de Janeiro em fragmentos. Rio de Janeiro: Ed. da UFRJ; Campinas, SP: Ed. da UNICAMP, 1993.

. "Lima Barreto: a opção pela Marginália". In: SCHWARZ,

Roberto (org.). Os Pobres na Literatura Brasileira. São Paulo: Brasiliense, 1983.

Rio de Janeiro. Prefeitura da cidade do Rio de Janeiro. Secretaria Municipal de Educação e Cultura. Departamento Geral de Cultura. Exposição O Rio de Janeiro de Lima Barreto. Rio de Janeiro, [198-].

SANTOS, Walter Mendes dos. Temas stendhalianos e intertexto balzaquiano em Lima Barreto. In: SEGUNDO ENCONTRO DA PESQUISA DE PÓSGRADUAÇÃO E INICIAÇÃO CIENTíFICA EM FRANCÊS, [s.d.], USP, São Paulo.

Disponível em: http://dlm.fflch.usp.br/sites/dlm.fflch.usp.br/files/Walter\%20Mendes\%20dos\%20 Santos.pdf. Acesso em: 10 de novembro de 2011.

SILVA, Luiz. A Consciência do Impacto nas Obras de Cruz e Souza e de Lima Barreto. Campinas, 2005. 232 f. Tese (Doutorado) - Instituto de Estudos da Linguagem, Universidade de Campinas. 
. Lima Barreto. São Paulo: Selo Negro, 2011. (Coleção Retratos do

Brasil Negro).

SILVA, Maurício. A Hélade e o Subúrbio - confrontos literários na Belle Époque carioca. São Paulo: Edusp, 2006.

\section{Obras gerais}

ABDALA JR, Benjamin. Literatura, história e política: literaturas de língua portuguesa no século XX. 2. ed. São Paulo: Ateliê Editorial, 2007. . De vôos e ilhas: literatura e comunitarismos. São Paulo: Ateliê Editorial, 2003.

ADORNO, Theodor. Notas de literatura I. São Paulo: Duas Cidades; Editora 34, 2003.

AGUIAR, Flávio; MEIHY, José Carlos Sebe; VASCONCELOS, Sandra Guardini T. (orgs.). Gêneros de Fronteira: cruzamentos entre o histórico e o literário. São Paulo: Xamã, 1997.

AGUIAR, Flávio e VASCONCELOS, Sandra. Ángel Rama: literatura e cultura na América Latina. São Paulo: Edusp, 1981.

ALCOFORADO, Maria Letícia Guedes. As marcas da França nos romances de Adolfo Caminha. São Paulo, 1982. 234 f. Tese (Doutorado) - Faculdade de Filosofia, Letras e Ciências Humanas, Universidade de São Paulo.

AMARAL, Glória Carneiro do. Aclimatando Baudelaire. São Paulo: Annablume, 1996.

ANDERSON, Benedict. Nação e consciência nacional. São Paulo: Ática, 1989. ASSIS, Machado de. Crítica Literária. São Paulo: Editora Brasileira, 1961. AULETE, Caldas. Dicionário contemporâneo da língua portuguesa. Rio de 
Janeiro: Delta, 1964.

AUERBACH, Erich. Mimesis. São Paulo: Perspectiva, 1976.

BARCELLOS, Sergio. Aproximações: teorias contemporâneas da literatura, identidade e diários. Revista de Estudos Literários Terra Roxa e outras terras, Rio de Janeiro: PUC, v. 9, p. 44-56, 2007.

BENJAMIN, Walter. Magia e Técnica, arte e política: ensaios sobre literatura e história da cultura. São Paulo: Brasiliense, 1987. (Obras escolhidas; vol. I).

BOSI, Alfredo. História Concisa da Literatura Brasileira. São Paulo: Cultrix, 2006.

- Literatura e Resistência. São Paulo: Companhia da Letras,

2002.

BOXER, Charles R. Relações raciais no império colonial português 1415 1825. Rio de Janeiro: Tempo Brasileiro, 1967.

BROCA, Brito. A vida literária no Brasil - 1900. 5a ed. Rio de Janeiro: José Olympio: Academia Brasileira de Letras, 2005.

CAMPOS, Augusto de. Patrícia Galvão, Pagu: vida, obra. São Paulo: Brasiliense, 1982.

CAMPOS, Humberto de. Diário Secreto. Rio de Janeiro: Edições O Cruzeiro, 1954. 2 v.

CANCLINI, Néstor García. Culturas híbridas. São Paulo: Edusp, 2000.

CANDIDO, Antonio. Literatura e sociedade, estudo de teoria e história literária. São Paulo: Companhia Ed. Nacional, 1965.

. Sílvio Romero: teoria, crítica e história literária. Rio de Janeiro: Livros Técnicos e Científicos; São Paulo: Edusp, 1978. (Biblioteca universitária de literatura brasileira). 
. O discurso e a cidade. São Paulo: Duas Cidades, 1993.

. A Educação pela noite. Rio de Janeiro: Ouro sobre Azul,

2006.

. Formação da Literatura Brasileira - momentos decisivos

1750-1880. Rio de Janeiro: Ouro sobre Azul, 2007.

CARA, Salete Almeida. A viagem das teorias literárias no início do século brasileiro. In: CONGRESSO ABRALIC, 3, 1992, Niterói. Anais: Limites. São Paulo: Edusp; Niterói, Rio de Janeiro: ABRALIC, 1995, p. 633-638.

CARELLI, Mario. Culturas cruzadas: Intercâmbios culturais entre França e Brasil. Trad. Nícia Adan Bonatti. Campinas, SP: Papirus, 1994.

CARNEIRO, Maria Luiza Tucci. Preconceito racial - Portugal e Brasil-Colônia. São Paulo: Brasiliense, 1988.

CARVALHAL, Tania Franco. O próprio e o alheio: ensaios de literatura comparada. São Leopoldo, RS: Ed. Unisinos, 2003.

CARVALHO, José Murilo de. Os bestializados. O Rio de Janeiro e a República que não foi. São Paulo: Companhia das Letras, 1987.

A Formação das almas: o imaginário da

República no Brasil. São Paulo: Companhia das Letras, 1990.

CHALHOUB, Sidney. Visões da Liberdade: Uma História das Últimas Décadas da Escravidão na Corte. São Paulo: Companhia das Letras, 1990.

CHARTIER, Roger (org.). História da vida privada, 3: da Renascença ao Século das Luzes. Trad. Hildegard Feist. São Paulo: Companhia das Letras, 1991.

CHAVES, Rita e MACEDO, Tânia (orgs.) Literaturas em movimento. São Paulo: Arte e Ciência, 2003.

COMPAGNON, Antoine. La seconde main ou le travail de la citation. Paris: 
Seuil, 1979.

COMPAGNON, Antoine. O trabalho da citação. Trad. Cleonice B. P. Mourão. Belo Horizonte: Editora UFMG, 1996.

COMTE, Auguste. Curso de Filosofia Positiva; Discurso sobre o espírito positivo; Discurso preliminar sobre o conjunto do positivismo; Catecismo positivista. Trad. José Arthur Giannotti e Miguel Lemos. 2. ed. São Paulo: Abril Cultural, 1983. (Os Pensadores).

COUTINHO, Afranio e SOUSA, J. Galante de. Enciclopédia de Literatura Brasileira. São Paulo: Global Editora; Fundação Biblioteca Nacional, 2001. v. 1. COUTINHO, Eduardo e CARVALHAL, Tânia (orgs.). Literatura comparada: textos fundadores. Rio de Janeiro: Rocco, 1994.

CUNHA, Antonio Geraldo da. Dicionário Etimológico Nova Fronteira da Língua Portuguesa. Rio de Janeiro: Nova Fronteira, 1982.

DARNTON, Robert. O grande massacre de gatos, e outros episódios da história cultural francesa. Trad. Sonia Coutinho. Rio de Janeiro: Graal, 1986.

DEGLER, Carl. Nem preto nem branco: escravidão e relações raciais no Brasil e nos Estados Unidos. Trad. Fanny Wrobel. Rio de Janeiro: Editorial Labor do Brasil, 1976.

DELACAMPAGNE, Christian. Une histoire du racisme. Des origines à nos jours. Paris: France Culture, 2000.

Dicionário Brasileiro da Língua Portuguesa. São Paulo: Gráfica Melhoramentos, 2000. v. 2.

DIDIER, Béatrice. Le journal intime. Paris: Presses Universitaire de France, 2002.

DORLIN, Elsa. La matrice de la race; généalogie sexuelle et coloniale de la 
nation française. Paris: Éditions La Découverte, 2006.

FANON, Franz. Os condenados da terra. Rio de Janeiro: Civilização brasileira, 1979.

FARIA, João Roberto. A Recepção de Zola e do Naturalismo nos Palcos Brasileiros. Revista Estudos Avançados: Coleção documentos. Série estudos Brasil-França. São Paulo, n. 4, 1998. Disponível em: www.iea.usp.br/artigos. Acesso em: 01 de junho de 2011.

FASSIN, Didier e FASSIN, Éric (orgs.). De la question sociale à la question raciale? Paris: Éditions La Découverte, 2006.

FAUSTO, Boris. História do Brasil. 13. ed. São Paulo: Edusp, 2008.

FERNANDES, Florestan. O negro no mundo dos brancos. 2.ed. São Paulo: Global, 2007.

FERREIRA, Aurélio Buarque de Holanda. Aurélio século XXI: o dicionário da língua portuguesa. Coordenação e edição Aurélio Buarque de Holanda Ferreira, Margarida dos Anjos, Marina Baird Ferreira. Rio de Janeiro: Nova Fronteira, 1999.

FERREIRA, Ligia Fonseca. Luiz Gama (1830-1882) : étude sur la vie et l'oeuvre d'un noir citoyen, poète et militant de la cause antiesclavagiste au Brésil. Paris, 2001. 2 v. Tese (Doutorado) - Université Paris III.

. "Negritude", "negridade", "negrícia": história e sentidos de três conceitos viajantes. Revista Via Atlântica, São Paulo, n. 9, p. 163-183, 2006.

FONSECA, Maria Nazareth. Brasil afro-brasileiro. Belo Horizonte: Autêntica, 2000.

FOUCAULT, Michel. Ética, sexualidade, política. Organização e seleção de 
textos Manoel Barros da Motta. Trad. Elisa Monteiro, Inês Autran Dourado Barbosa. 2 ed. Rio de Janeiro: Forense Universitária, 2006.

- Problematização do Sujeito: Psicologia, Psiquiatria e

Psicanálise. Organização e seleção de textos Manoel Barros da Motta. Trad. Vera Lucia Avellar Ribeiro. 2 ed. Rio de Janeiro: Forense Universitária, 2006.

FRANCO, Maria Sylvia de Carvalho. Homens livres na ordem escravocrata. São Paulo: Ática, 1974.

FRIEDRICH, Hugo. Estrutura da lírica moderna. São Paulo: Duas cidades, 1991.

FRY, Peter. A Persistência da Raça. Ensaios Antropológicos sobre o Brasil e a África Austral. Rio de Janeiro: Civilização Brasileira, 2005.

GAMA, Luiz. Primeiras trovas burlescas e outros poemas. Organização e introdução Ligia Fonseca Ferreira. São Paulo: Martins Fontes, 2000.

. Com a palavra, Luiz Gama: poemas, artigos, cartas, máximas.

Organização, introdução e notas Ligia Fonseca Ferreira. São Paulo: Imprensa Oficial do Estado de São Paulo, 2011.

GARMES, Hélder. O pensamento mestiço e uma poética da mestiçagem. Revista Via Atlântica, São Paulo, n. 05 , p. 182-185, 2002.

GIRARD, Alain. Le journal intime. Paris: Presses Universitaires de France, 1963.

GOBINEAU, Arthur de. Essai sur l'inégalités des races humaines. Disponível em:http://classiques.uqac.ca/classiques/gobineau/essai_inegalite_races/essai_i negalite_races.html. Acesso em: 10 de novembro de 2011.

GORENDER, Jacob. O Escravismo Colonial. 5aㅡ ed. São Paulo: Ática, 1988.

GOULD, Stephen Jay. A falsa medida do homem. Trad. Valter Lellis Siqueira. 
São Paulo: Martins Fontes, 1999.

GRUZINSKI, Serge. O pensamento mestiço. São Paulo: Companhia das Letras, 2001.

GUSDORF, Georges. Les écritures du moi - Lignes de vie 1. Paris: Odile Jacob, 1991.

HOBSBAWN, Eric. A invenção das tradições. Rio de Janeiro: Paz e Terra, 1984.

HOFBAUER, Andréas. Uma história de branqueamento ou o negro em questão. São Paulo, 1999. 375 f. Tese (Doutorado) - Faculdade de Filosofia, Letras e Ciências Humanas, Universidade de São Paulo.

HOLANDA, Sérgio Buarque de (org.). O Brasil Monárquico, v.5: reações e transações. Por Francisco Iglésias et alii. 8a․ Ed. Rio de Janeiro: Bertrand Brasil, 2004a.

- O Brasil Monárquico, v.6: declínio e queda. Por Myrian Ellis et alii. 6a․ Ed. Rio de Janeiro: Bertrand Brasil, 2004b.

HOUAISS, Antônio e VILLAR, Mauro de Salles. Dicionário Houaiss da Língua Portuguesa. Lisboa: Temas e Debates, 2003. t. I, II e III.

LACERDA, João Batista de. Sobre os mestiços no Brasil. 1911, [s.d.t.].

LARANJEIRA, Pires. Literaturas Africanas de expressão portuguesa. Lisboa: Universidade Aberta, 1995.

LEFEBVRE, Henri. Introdução à Modernidade: prelúdios. Trad. Jehovanira Chrysóstomo de Souza. Rio de Janeiro: Paz e Terra, 1969.

LEITE, Dante Moreira. O amor romântico e outros temas. São Paulo: Ed. Nacional; Ed. da Universidade de São Paulo, 1979.

LEJEUNE, Philippe. "Cher cahier ..." Témoignages sur Le journal personnel. 
Paris: Gallimard, 1989.

. Le Pacte Aubiographique. Paris: Éditions du Seuil, 1996.

- O pacto autobiográfico: de Rousseau à internet.

Organização Jovita Maria Gerheim Noronha. Trad. Jovita Maria Gerheim Noronha e Maria Inês Coimbra Guedes. Belo Horizonte: Editora UFMG, 2008.

LEVINE, Michael P. e PATAKI, Tamas (orgs.). Racismo em mente. Trad. Fábio Assunção L. Rezende. São Paulo: Madras, 2005.

LISBOA, Karen Macknow. Viagem pelo Brasil de Spix e Martius: Quadros da Natureza e Esboços de uma Civilização. Revista Brasileira de História, São Paulo, v. 15, n. 29, $1995 . \quad$ Disponível em: http://www.anpuh.org/revistabrasileira/view?ID_REVISTA_BRASILEIRA=14. Acesso em: 21 de outubro de 2011.

MACHADO, José Pedro. Dicionário etimológico da língua portuguesa: com a mais antiga documentação escrita e conhecida de muitos dos vocábulos estudados. Lisboa: Editorial Confluência, 1952-1959. v. II.

MACIEL, Sheila Dias. Diários: escrita e leitura do mundo. Analecta, Mato Grosso do Sul, v. 3, n. 1, 2002. Disponível em: http://www.unicentro.br/editora/revistas/analecta/v3n1/artigo\%205\%20diarios.p df. Acesso em: 23 de junho de 2007.

MAGALHÃES, José Vieira Couto de. Diário do General Couto de Magalhães. São Paulo: [s.n.], 1974.

Diário Íntimo. Organização Maria Helena

P. T. Machado. São Paulo: Companhia das Letras, 1998.

MARTIUS, Carl Friedrich Philipp von. Como se deve escrever a História do Brasil. Revista do IHGB, Rio de Janeiro, 1844. t. 6. 
MEMMI, Albert. O retrato do colonizado precedido do colonizador. Rio de Janeiro: Paz e Terra, 1967. . O Racismo. Lisboa: Caminho, 1993.

MILLIET, Sérgio. Diário crítico. 2 ed. São Paulo: Martins, 1981.

MOORE, Carlos. Racismo e sociedade. Belo Horizonte: Maaza, 2007.

MUNANGA, Kabengele. Construção da identidade negra: diversidade de contextos e problemas ideológicos. São Paulo: Educ, 1988. . "Uma abordagem conceitual das noções de raça, racismo, identidade e etnia". In: BRANDÃO, André Augusto P. Programa de educação sobre o negro na sociedade brasileira. Rio de Janeiro: EDUFF, 2004. . Rediscutindo a mestiçagem no Brasil: Identidade nacional versus identidade negra. Belo Horizonte: Autêntica, 2008. NABUCO, Joaquim. A escravidão. Recife: Fundação Joaquim Nabuco, Ed. Massangana, 1988.

- Diários. Rio de Janeiro: Bem-te-Vi; Recife: Fundação Joaquim Nabuco, Ed. Massangana, 2005. 2 v.

NEEDELL, Jeffrey D. Belle époque tropical: Sociedade e cultura de elite no Rio de Janeiro na virada do século. Trad. Celso Nogueira. São Paulo: Companhia das Letras, 1993.

ORTIZ, Renato. Cultura brasileira e identidade nacional. São Paulo: Brasiliense, 2006.

PASSOS, Gilberto Pinheiro. A poética do Legado: presença francesa em Memórias Póstumas de Brás Cubas. São Paulo: Annablume, 1996.

PERROT, Michelle (org.). História da vida privada, 4: da Revolução Francesa à Primeira Guerra. Trad. Denise Bottmann, partes 1 e 2; Bernardo Joffily, partes 
3 e 4. São Paulo: Companhia das Letras, 1991.

PETRUCCELLI, José Luis. Doutrinas francesas e o pensamento racial brasileiro, 1870-1930. Estudos Sociedade e Agricultura, Rio de Janeiro: Programa de Pós-graduação em Desenvolvimento, Agricultura e Sociedade, n. 7 , 1996.

Disponível

em:

http://bibliotecavirtual.clacso.org.ar/ar/libros/brasil/cpda/estudos/sete/petruc7.ht m. Acesso em: 09 de junho de 2011.

POLIAKOV, Leon (org.). O Mito Ariano. São Paulo: Perspectiva; Edusp, 1974. . Hommes et Bêtes: entretiens sur le racisme. Paris: Mouton, 1975.

QUEIROZ JUNIOR, Teófilo de. Preconceito de cor e a mulata na literatura brasileira. São Paulo: Ática, 1975.

QUERINO, Manuel. A Raça africana e os seus costumes. Salvador: Progresso, 1955.

RAEDERS, Georges. O Inimigo cordial do Brasil. Rio de Janeiro: Paz e Terra, 1988.

. O Conde de Gobineau no Brasil. Trad. Rosa Freire de Aguiar. Rio de Janeiro: Paz e Terra, 1996. (Coleção Leitura). RODRIGUES, Nina. Mestiçagem, degenerescência e crime. [s.d.t.] ROUSSEAU, Jean-Jacques. Confessions. Paris: Gallimard, 2009. . As Confissões. Trad. Wilson Lousada. Rio de

Janeiro: Ediouro, [19-].

RICOEUR, Paul. O si-mesmo como um outro. São Paulo: Papirus, 1991. ROMERO, Sílvio. Literatura, História e Crítica. Organização Luiz Antonio Barreto. Rio de Janeiro: Imago; Aracaju, SE: Universidade Federal de Sergipe, 
2002.

SCHWARCZ, Lília Moritz e QUEIROZ, Renato da Silva (org.). Raça e diversidade. São Paulo: Edusp; Estação Ciência, 1996.

SCHWARCZ, Lília Moritz. O espetáculo das raças. São Paulo: Companhia das Letras, 1993.

. Racismo no Brasil. São Paulo: Publifolha, 2001.

(org.). História da vida privada no Brasil, 4: Contrastes da intimidade contemporânea. São Paulo: Companhia das Letras, 2002.

As barbas do Imperador: D. Pedro II, um monarca nos trópicos. 2ª ed. São Paulo: Companhia das Letras, 2007. . Usos e abusos da mestiçagem e da raça no Brasil: uma história das teorias raciais em finais do século XIX. Afro-Ásia, n. 18, 1996, p.77-101. Disponível em: http://www.afroasia.ufba.br/pdf/afroasia_n18_p77.pdf. Acesso em: 10 de novembro de 2011.

SEYFERTH, Giralda. João Batista de Lacerda: a antropologia física e a tese do branqueamento da raça no Brasil. [s.d.t.].

SEVCENKO, Nicolau. Literatura como missão: Tensões sociais e criação cultural na Primeira República. São Paulo: Companhia das Letras, 2003.

SIMONET-TENANT, Françoise. Le journal intime - genre littéraire et écriture ordinaire. Paris: Téraèdre, 2004.

SKIDMORE, Thomas. Preto no branco: raça e nacionalidade no pensamento brasileiro. Trad. Raul de Sá Barbosa. Rio de Janeiro: Paz e Terra, 1976.

SOARES, Mozart Pereira. A influência de Augusto Comte no pensamento brasileiro. Episteme, Porto Alegre, v. 3, n. 6, p. 144-153, 1998. Disponível em: http://www.ilea.ufrgs.br/episteme/portal/pdf/numero06/episteme06_artigo_soare 
s.pdf. Acesso em: 29 de julho de 2011.

SODRÉ, Nelson Werneck. O Naturalismo no Brasil. Belo Horizonte: Oficina de Livros, 1992.

SOUSA, Cruz e. Obra completa: prosa. Organização e estudo Lauro Junkes. Jaraguá do Sul: Avenida, 2008. v. 2.

VENTURA, Roberto. Estilo Tropical: História Cultural e Polêmicas Literárias no Brasil: 1870-1914. São Paulo: Companhia das Letras, 1991.

VERÍSSIMO, José. História da Literatura Brasileira. São Paulo: Editora Letras \& Letras, 1998.

. José Veríssimo: teoria, crítica e história literária. Seleção e apresentação João Alexandre Barbosa. Rio de Janeiro: Livros Técnicos e Científicos; São Paulo: Edusp, 1977. (Biblioteca universitária de literatura brasileira).

VIANA, Oliveira. Raça e Assimilação. Rio de Janeiro: José Olympio, 1959.

ZOLA, Émile. O Romance Experimental e o Naturalismo no Teatro. Trad. Ítalo Caroni e Célia Berrettini. São Paulo: Editora Perspectiva, 1979. . Germinal. Trad. Silvana Salermo. São Paulo: Companhia das Letras, 2000.

WIEVIORKA, Michel. O Racismo, uma introdução. Trad. Fany Kon. São Paulo: Perspectiva, 2007. 
Anexos 


\section{Cronologia de Lima Barreto ${ }^{89}$}

1881 - 13 de maio: Afonso Henriques de Lima Barreto nasce no Rio de Janeiro, filho legítimo de João Henriques de Lima Barreto e Amália Augusta Barreto.

- 13 de outubro: É batizado na Igreja Matriz de N. S. da Glória, no Rio de Janeiro. Sendo seu padrinho Afonso Celso de Assis Figueiredo, futuro visconde de Ouro Preto.

- Machado de Assis publica Memórias Póstumas de Brás Cubas.

1882 - Falece, aos 52 anos, em São Paulo, Luiz Gama.

1887 - Em dezembro, morre sua mãe, de tuberculose galopante.

1888 - Começa a frequentar a Escola Pública Municipal.

- 13 de maio: Em companhia de seu pai, Lima assiste às comemorações da Abolição da Escravatura.

1889 - João Henriques, pai do escritor, é promovido de chefe de turma a mestre das oficinas de composição da Imprensa Nacional. Trabalhava também como paginador da Tribuna Liberal, de propriedade do Visconde de Ouro Preto.

- 15 de novembro: Proclamação da República.

1890 - Fevereiro: João Henriques é demitido da Imprensa Nacional.

- Março: João Henriques é nomeado escriturário das Colônias de Alienados da llha do Governador.

- Novembro: Lima recebe, como prêmio escolar, um exemplar da obra de Luís Figuier: As grandes invenções.

- Instalação da Assembléia Nacional Constituinte.

1891 - Matricula-se, como aluno interno, no Liceu Popular Niteroiense.

- Março: João Henriques é promovido a almoxarife das Colônias de Alienados da Ilha do Governador.

${ }^{89}$ Baseada na "Sinopse Cronológica" de Lima Barreto, elaborada por Francisco de Assis Barbosa (2003, p. 403-410). 
- Deodoro da Fonseca fecha o Congresso Nacional; contragolpe de Floriano Peixoto leva-o ao poder para restaurar a ordem constitucional.

1893 - João Henriques é nomeado administrador das Colônias.

- A Armada revolta-se no Rio; Revolução Federalista no Sul.

1894 - Prudente de Morais assume a presidência da República.

1895 - Janeiro: Lima faz exame de Português, no Ginásio Nacional (RJ). Aprovado.

- Agosto: Faz exame de Francês. Aprovado.

- Falece, aos 56 anos, no Rio de Janeiro, Floriano Peixoto (segundo presidente do Brasil).

1896 - Janeiro: Faz exames de História geral e do Brasil, Aritmética. Aprovado.

- Março: Conclui os primeiros preparatórios no Colégio Paula Freitas (curso anexo de preparatórios à Escola Politécnica).

1897 - Ingressa na Escola Politécnica do Rio de Janeiro.

- Passa a frequentar a Biblioteca Nacional.

1898 - Faz exames de Cálculo e Geometria Descritiva, cadeiras que faltam para completar o primeiro Ano. Reprovado em ambas.

- Leituras na Biblioteca Nacional.

- Campos Sales inicia seu governo como presidente da República.

- Falece, aos 36 anos, no município de Antônio Carlos, Minas Gerais, o poeta Cruz e Sousa.

1899 - Fevereiro: Faz exames de segunda época. Aprovado em Geometria, reprovado em Cálculo.

- Maio: Renova a matrícula no primeiro ano. Matricula-se como ouvinte no segundo.

- Novembro: Faz exame de Cálculo. Reprovado. 
1900 - Fevereiro: Reprovado novamente em Cálculo.

- Viagem a Barbacena, em exercícios práticos da cadeira de Topografia.

- Novembro: Aprovado no exame de Cálculo, assim como em todas as cadeiras do segundo ano, exceto em Mecânica Racional.

- A Biblioteca Nacional continua a ser seu refúgio.

1901 - Fevereiro: Reprovado em exame (segunda época) de Mecânica.

- Abril: Matricula-se no segundo ano, pois continua repetente em Mecânica. Matricula-se também no terceiro ano, como ouvinte.

- Leituras na Biblioteca Nacional.

1902 - Março: Reprovado novamente em Mecânica.

- Agosto: João Henriques, pai do escritor, enlouquece.

- Lima inicia sua colaboração em jornais acadêmicos, escrevendo para $A$ Lanterna, a convite de Bastos Tigre, com quem edita um periódico de curta duração: A Quinzena Alegre.

- A família de Lima muda-se da llha do Governador para o Rio de Janeiro, indo residir no engenho Novo, à Rua Vinte e quatro de maio, no 123.

- Rodrigues Alves assume o poder e começa a reconstruir e sanear o Rio de Janeiro.

1903 - Março: Decreto, aposentando João Henriques.

- Reprovado pela quinta vez em Mecânica. Matricula-se novamente no segundo ano e como ouvinte no terceiro.

- Colabora no Tagarela sob o pseudônimo de Rui de Pina.

- Candidata-se a uma vaga de amanuense na Secretaria de Guerra, é classificado em segundo lugar, mesmo assim é nomeado para ocupar o cargo.

- Colabora no semanário O Diabo, de Bastos Tigre.

- É secretário da Revista da Época, por alguns meses.

- Passa a residir em Todos os Santos, à Rua Boa Vista, no 76.

1904 - Começa a escrever a primeira versão de Clara dos Anjos. 
1905 - Abril: Passa a trabalhar como jornalista profissional, escrevendo uma série de reportagens para o jornal Correio da Manhã, sob o título: "Os subterrâneos do morro do castelo".

- 12 de julho: Data do prefácio das Recordações do escrivão Isaías Caminha: por essa época provavelmente começou a escrever o livro.

1906 - 8 de outubro: Data do prefácio de Vida e Morte de M. J. Gonzaga de Sá; provavelmente escreveu esse livro por essa época, mas só o publicou em 1919.

- 10 de outubro: Entra em licença para tratamento de saúde, até 15/01/1907.

1907 - Funda no Rio a Revista Floreal, onde publica os dois primeiros capítulos de Recordações do escrivão Isaías Caminha. Revista que perdurou apenas por 4 números.

1908 - Falece, aos 69 anos, no Rio de Janeiro, Machado de Assis.

1909 - Aparece em Lisboa o romance Recordações do Escrivão Isaías Caminha, publicado pelo editor M. Teixeira, os originais foram levados por Antonio Noronha Santos.

- Falece, aos 61 anos, no Rio de Janeiro, Afonso Pena (sexto presidente do Brasil). Sucedido por Nilo Peçanha.

1910 - Hermes da Fonseca inicia o governo das "salvações nacionais".

- Lima toma parte no júri da Primavera de Sangue.

- Viagem a Juiz de Fora.

- Notas para elaboração de Triste fim de Policarpo Quaresma.

- Licença para tratamento de saúde, até 28/02/1911. Diagnóstico: Impaludismo.

1911 - O Jornal do Commercio começa a publicar em folhetins o romance Triste Fim de Policarpo Quaresma.

1912 - Lima Barreto colabora no jornal A Gazeta da Tarde. 
- 1 de fevereiro: Licença para tratamento de saúde até 30/04 do mesmo ano. Diagnóstico: reumatismo poli-articular, hipercinese cardíaca.

- setembro: Publica os dois fascículos das Aventuras do Doutor Bogóloff.

1913 - 13 de setembro: Muda-se para a Rua Major Mascarenhas, № 42, em Todos os Santos.

1914 - Venceslau Brás chega ao poder em meio à grave crise econômica.

- 19 de junho: Passa a escrever uma crônica, diariamente para o Correio da Noite.

- 18 de agosto: Primeira estada no Hospício, até 13/10. Diagnóstico: alcoolismo.

- 1 de novembro: Licença para tratamento de saúde até janeiro de 1915. Diagnóstico: neurastenia.

- Falece, aos 63 anos, no Rio de Janeiro, Silvio Romero.

1915 - O jornal A Noite começa a publicar em folhetins Numa e Ninfa.

- Lima passa a colaborar com a Careta, até 24/06/1916.

- Dívidas, bebedeiras.

1916 - 26 de fevereiro: Aparece em volume Triste fim de Policarpo Quaresma.

- junho: Viagem a Ouro Fino (MG).

- 16 de junho: Licenciado para tratamento de saúde, até 17/07. Diagnóstico: neurastenia, com anemia pronunciada.

- 25 de dezembro: Inicia sua colaboração no A.B.C.

- Falece, aos 59 anos, no Rio de Janeiro, José Veríssimo.

1917 - Crises e greves operárias alastram-se pelo país. Lima Barreto atua na imprensa anarquista, apoiando a plataforma libertária dos trabalhadores.

- julho: Recolhido, enfermo, ao Hospital Central do Exército.

- Entrega ao editor Jacinto Ribeiro do Santos os originais de Os Bruzundangas, que só aparecerão em volume em dezembro de 1922, após a morte de Lima. 
- 21 de agosto: Em carta a Rui Barbosa, declara-se candidato à Academia Brasileira de Letras. A inscrição não foi considerada.

- setembro: Aparecimento da segunda edição de Recordações do Escrivão Isaías Caminha.

- Aparecimento de Numa e Ninfa em volume.

1918 - 17 de janeiro: Começa a publicar crônicas em $A$ Lanterna, sob o pseudônimo de Dr. Bogóloff.

- 11 de maio: Lança no A.B.C. seu manifesto maximalista. Em julho escreve artigo manifestando sua simpatia pela Revolução Russa, no semanário Brás Cubas.

- 4 de novembro: É recolhido ao Hospital Central do Exército com a clavícula quebrada, onde fica até 5/01/1919. Remete, do hospital, a Monteiro Lobato, os originais do romance Vida e morte de M. J. Gonzaga de Sá.

- 26 de dezembro: Por ter sido considerado "inválido para o serviço público", é aposentado de seu cargo na Secretaria da Guerra. Muda-se para a Rua Major Mascarenhas, ㄲo 26.

1919 - Epitácio Pessoa assume a presidência da República.

- 1 de fevereiro: Suspende a sua colaboração no A.B.C., por ter sido publicado nessa revista um artigo contra a raça negra.

- 22 de fevereiro: Aparece a primeira edição do romance Vida e Morte de M. F. Gonzaga de Sá.

- 24 de fevereiro: Candidato à Academia Brasileira de Letras.

- 20 de março: Começa a publicar crônicas de folclore urbano, no semanário Hoje.

- 13 de setembro: Início da segunda fase de colaboração em a Careta.

- 30 de outubro: Nova eleição para a Academia é eleito Humberto de Campos.

- 25 de dezembro: Segunda estada no Hospício, até 02/02/1920.

1920 - 4 de dezembro: Apresenta-se candidato ao prêmio da Academia Brasileira de Letras para o melhor livro publicado no ano anterior, com Vida $e$ 
Morte de M. F. Gonzaga de Sá.

- Aparece nas livrarias Histórias e Sonhos.

- Entrega ao editor Schettino os originais de Marginália, que se perderam.

- Pelo artigo "O nosso feminismo", recebe a única homenagem de sua vida: um almoço no Hotel Novo Democrata. O responsável por tudo foi o editor e livreiro Francisco Schettino, amigo de Lima, que ao autor se afeiçoara, considerando-o uma "extraordinária criatura que é só generosidade e meiguice".

1921 - janeiro: Publica um trecho do romance O cemitério do Vivos na Revista Souza Cruz.

- abril: Viagem a Mirassol (SP).

- A Academia Brasileira de Letras concede menção honrosa ao Vida e Morte de M. F. Gonzaga de Sá.

- junho: aparece o Gonzaga de Sá com nova capa.

- 1 de julho: Apresenta-se a candidato à Academia.

- 28 de setembro: Retira a sua candidatura à Academia.

- outubro/ novembro: Publica na Revista Sousa Cruz a conferência "O Destino da Literatura".

- dezembro: Começa a escrever Clara dos Anjos (segunda versão), que terminou em janeiro de 1922.

1922 - Semana de Arte Moderna em São Paulo.

- Entrega ao editor Schettino os originais de Feiras e Mafuás.

- maio: Publica na revista $O$ Mundo Literário o primeiro capítulo inédito de Clara dos Anjos.

- 1 de novembro: Lima falece, no Rio de Janeiro, aos 41 anos. Diagnóstico: gripe torácica e colapso cardíaco.

- Em 3 de novembro: Falece o pai do escritor. Ambos foram enterrados no cemitério São João Batista, no Rio de Janeiro.

1952 - É criada a Biblioteca Popular Municipal Lima Barreto, situada no Méier, recentemente reinaugurada após ampliação do espaço e acervo, em 14 de 
julho de 2011.

1953 - É lançada a primeira edição do Diário Íntimo, pela editora Mérito, preparada por Francisco de Assis Barbosa.

1956 - É lançada a Obra Completa de Lima Barreto (17 volumes), organizada por Francisco de Assis Barbosa em colaboração com Antonio Houaiss e M. Cavalcanti Proença, pela editora Brasiliense.

1961 - É reeditada a Obra Completa de Lima Barreto, sob direção do mesmo organizador, também pela editora Brasiliense.

1981 - O Departamento Geral de Cultura da Prefeitura da cidade do Rio de Janeiro organiza a exposição comemorativa do centenário de nascimento do autor "O Rio de Janeiro de Lima Barreto", no Arquivo Geral da cidade do Rio.

1982 - A escola de samba Unidos da Tijuca homenageia Lima Barreto com o samba enredo "Lima Barreto, mulato pobre, mas livre".

1989 - Um grupo de amigos cariocas, unidos pela admiração à vida e obra de Lima Barreto, decide formar a "Casa Lima Barreto". Inicialmente, alugaram um espaço à Rua Padre Nóbrega, no 100, onde permaneceram até 2000. Atualmente, se reúnem para bate-papo sobre o patrono, nos segundos sábados do mês no "Memórias do Rio", bar situado no bairro da Lapa, na cidade do Rio.

2001 - É reeditada parte da obra de Lima Barreto em Prosa Seleta, organizada por Eliane Vasconcellos, pela editora Nova Aguilar (volume único).

2011 - É erguido, na Rua do Lavradio, no 133, na cidade do Rio de Janeiro, busto de Lima Barreto, homenagem da cidade ao escritor, fruto da iniciativa da "Casa Lima Barreto". 


\section{ESCOLA DE SAMBA UNIDOS DA TIJUCA}

Samba enredo de 1982: "Lima Barreto, mulato, pobre, mas livre" Intérprete: Sobrinho

Autor: Adriano

Vamos recordar Lima Barreto

Mulato pobre, jornalista e escritor

Figura destacada do romance social

Que hoje laureamos neste carnaval

O mestiço que nasceu nessa cidade

Traz tanta saudade em nossos corações

Seus pensamentos, seus livros

Suas ideias liberais

Impressionante brado de amor pelos humildes

Lutou contra a pobreza e a discriminação

Admirável criador, ôô, ôô

De personagens imortais

Mesmo sendo excelente escritor

Inocente Barreto não sabia

Que o talento banhado pela cor

Não pisava o chão da academia

Vencido pela dor de uma tragédia

Que cobria de tristeza a sua vida

Entregou-se à bebida, aumentando seu sofrer

Sem amor, sem carinho

Esquecido morreu na solidão

Lima Barreto

Este seu povo quer falar só de você

A sua vida, sua obra é nosso enredo

E agora canta em louvor e gratidão 


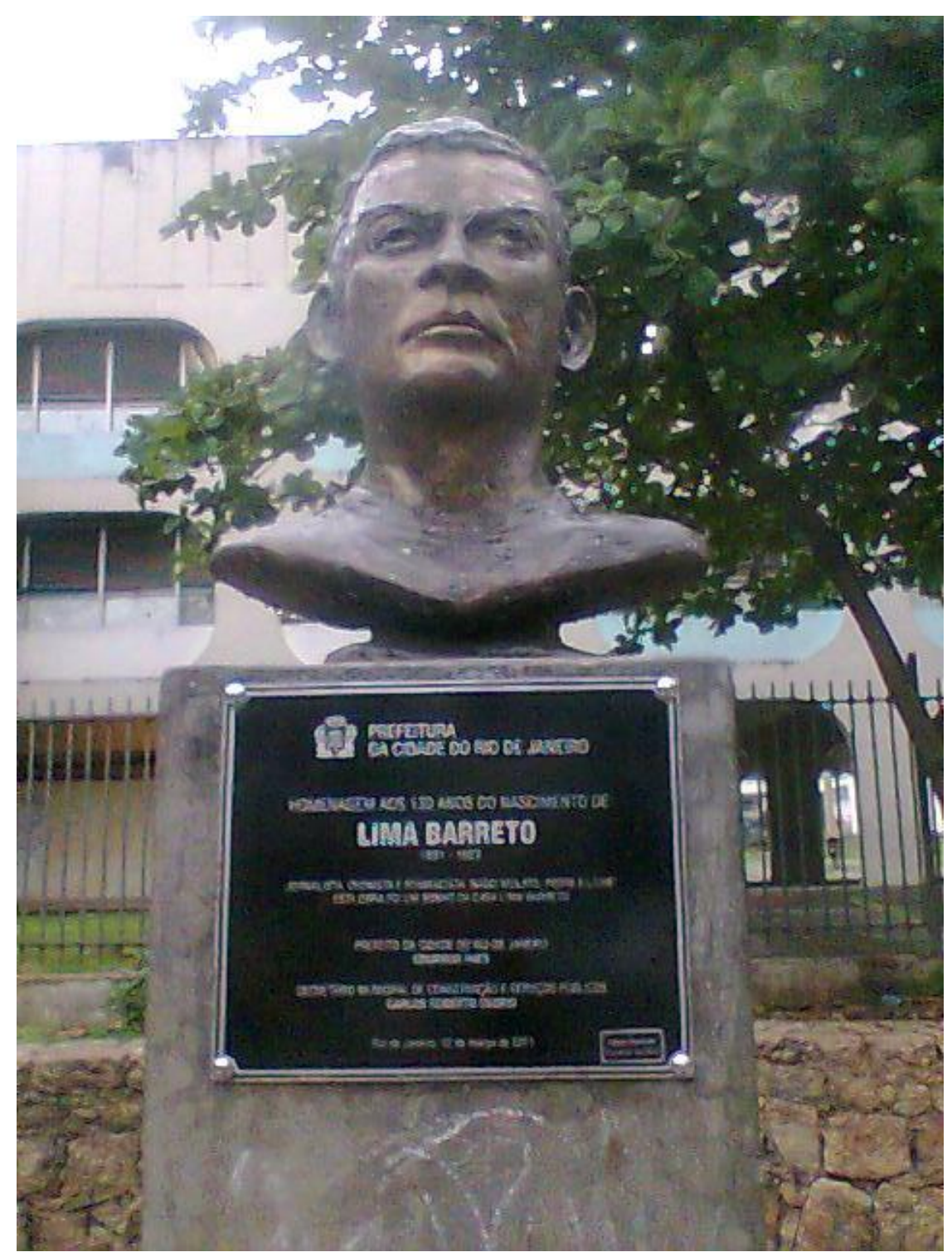




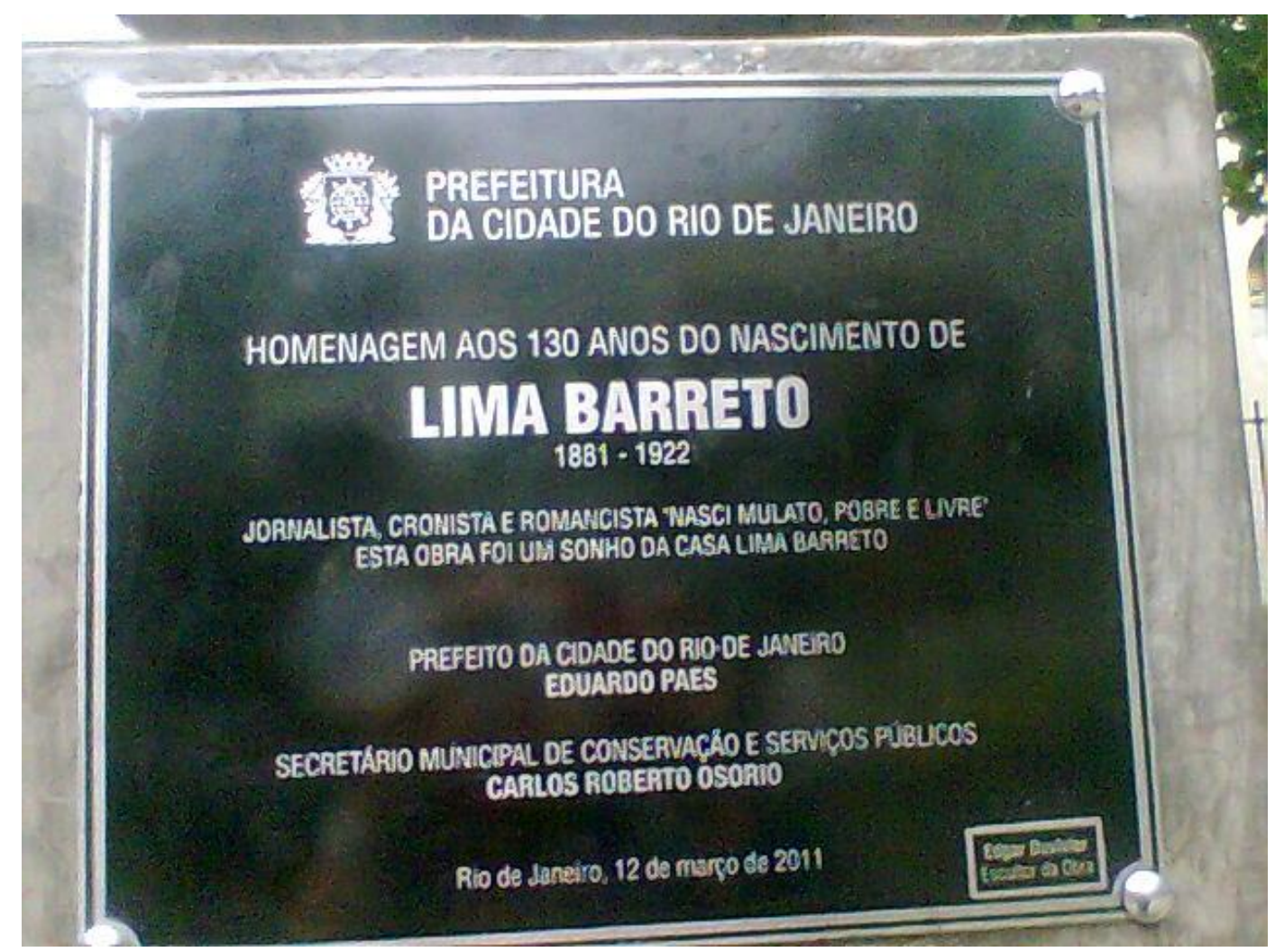

